\title{
ANNUAL SITE ENVIRONMENTAL REPORT
}

FOR CALENDAR YEAR 1999

United States Department of Energy

Western Area Power Administration

Environment

12155 W. Alameda Parkway

Lakewood, CO 80228-2802

DOE NO. WP/16151-14 


\section{DISCLAIMER}

This report was prepared as an account of work sponsored by an agency of the United States Government. Neither the United States Government nor any agency thereof, nor any of their employees, make any warranty, express or implied, or assumes any legal liability or responsibility for the accuracy, completeness, or usefulness of any information, apparatus, product, or process disclosed, or represents that its use would not infringe privately owned rights. Reference herein to any specific commercial product, process, or service by trade name, trademark, manufacturer, or otherwise does not necessarily constitute or imply its endorsement, recommendation, or favoring by the United States Government or any agency thereof. The views and opinions of authors expressed herein do not necessarily state or reflect those of the United States Government or any agency thereof. 


\section{DISCLAIMER}

Portions of this document may be illegible in electronic image products. Images are produced from the best available original document. 


\section{PREFACE}

The Department of Energy (DOE) Order 231.1, Chapter II.4, DOE 5400.1 and DOE 451.1A require the preparation of annual reports. To minimize the burden of annual reports to the DOE, the Western Area Power Administration (Western) has combined the reporting requirements found in these Orders into this Annual Site Environmental Report. These include reports required under DOE 231.1, with the Annual Summary of Environmental Permits report (DOE 5400.2A), the Annual NEPA Planning Summary (DOE 451.1) and the Annual Report on Mitigation Action Plans (DOE 451.1A). Because Western has over 400 facilities located in 17 states, this report addresses the environmental activities in all the facilities as one "site."

Western has established a formal environmental protection, auditing, monitoring, and planning program that has been in effect since 1978. The significant environmental projects and issues Western was involved with in 1999 are discussed in this Annual Site Environmental Report. This report is written to show the nature and effectiveness of the environmental protection program. 


\section{TABLE OF CONTENTS}

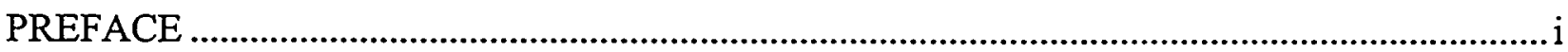

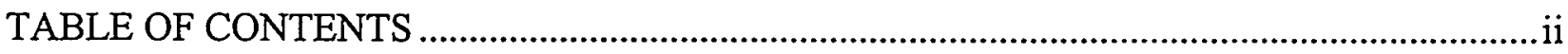

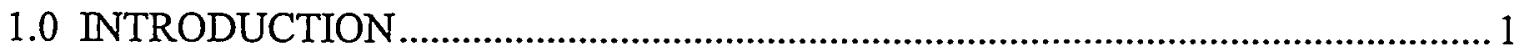

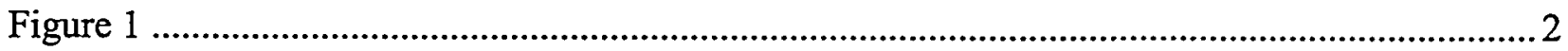

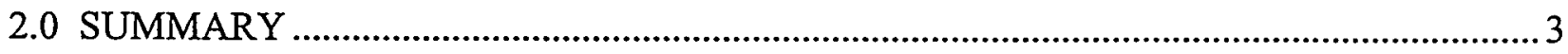

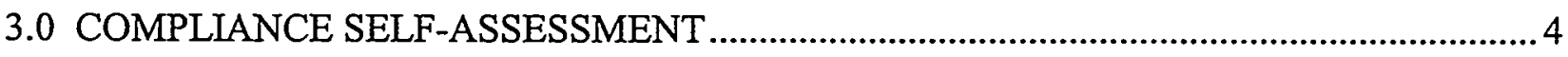

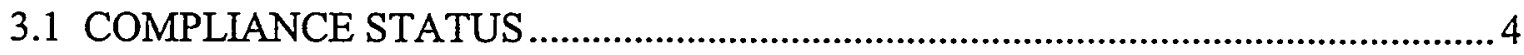

3.1.1 Resource Conservation and Recovery Act (RCRA) ....................................... 4

3.1.1.1 Underground Storage Tanks (UST) .............................................. 5

3.1.2 Toxic Substances Control Act (TSCA) ..................................................... 5

3.1.3 Comprehensive Environmental Response, Compensation, and Liability Act (CERCLA) ......................................................................... 6

3.1.3.1 Superfund Amendments and Re-authorization Act (SARA) .............6

3.1.3.2. Emergency Planning, Community Right-to

Know Act (EPCRA) .......................................................................... 7

3.1.4 Federal Insecticide, Fungicide, and Rodenticide Act (FIFRA)....................... 7

3.1.5 Clean Air.Act (CAA) ............................................................................ 9

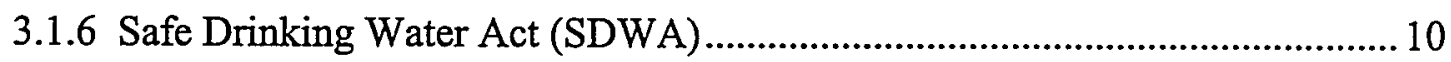

3.1.6.1 Underground Injection Control (UIC) ............................................. 10

3.1.6.2 Re-authorization of the SDWA ................................................. 10

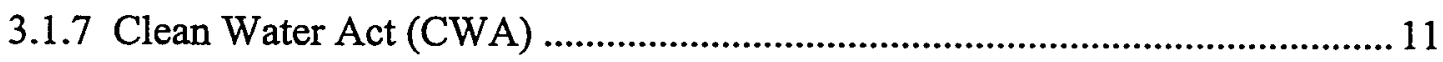

3.1.7.1 Spill Prevention, Control, and Countermeasures Plans (SPCC) ........ 11

3.1.7.2 Other Clean Water Act Issues ......................................................... 11

3.1.8 Hazardous Materials Transportation Act (HMTA) ...................................... 11

3.1.9 National Historic Preservation Act (NHPA) ............................................... 12

3.1.10 Native American Graves Protection and Repatriation Act (NAGPRA)........ 12

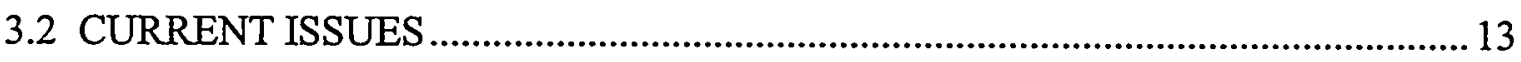

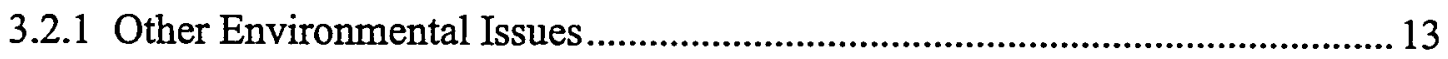

3.2.1.1 Lead Paint Management Program ...................................................... 13

3.2.1.2 Asbestos Management Program..................................................... 13

3.3 SUMMARY OF PERMITS ............................................................................ 13

TABLE 1. LIST OF ENVIRONMENTAL PERMITS OBTAINED OR

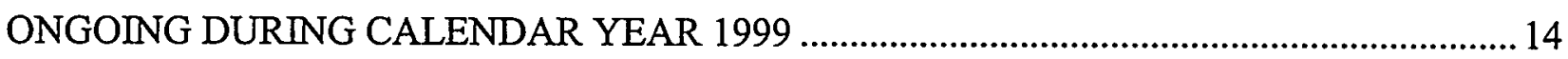

4.0 ENVIRONMENTAL PROGRAM INFORMATION .................................................... 15

4.1 ENVIRONMENTAL PROTECTION PROGRAMS........................................... 15

4.1.1 Environmental Management System (EMS) .............................................. 15

4.1.2 Emergency Planning, Community Right-to-know Act................................... 15 
4.1.3 Environmental Auditing Program................................................................... 16

4.1.4 Long Range Environmental Plan .............................................................. 17

4.1.5 Environmental Protection Compliance Information........................................... 17

4.1.6 Waste Minimization, Pollution Prevention and Affirmative Procurement ..... 18

4.1.7 Environmental Risk Assessment and Management.......................................... 19

4.2 STATE AND LOCAL ENVIRONMENTAL REQUIREMENTS .............................20

4.3 NEPA PLANNING SUMMARY ………………..................................................20

TABLE 2. ENVIRONMENTAL PLANNING PROJECTS ONGOING

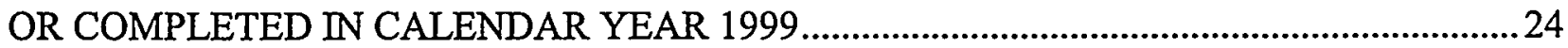

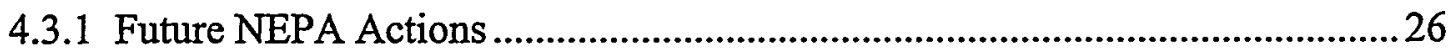

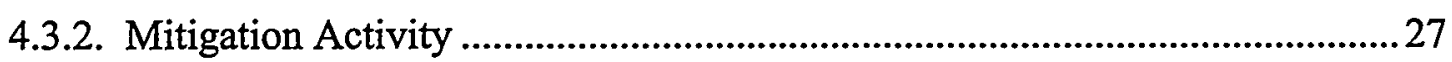

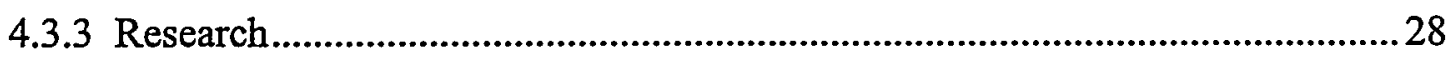

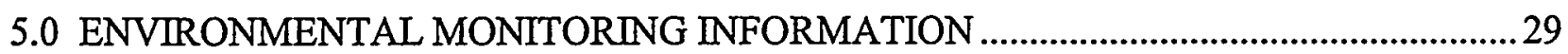

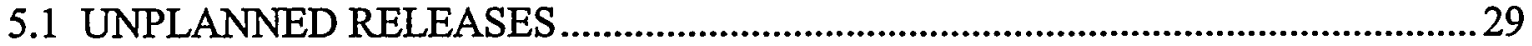

TABLE 3. LIST OF HAZARDOUS MATERIAL RELEASES

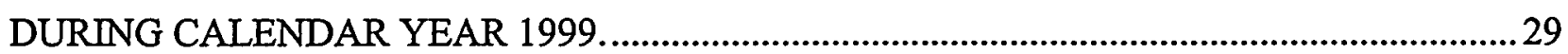

6.0 GROUNDWATER MONITORING AND PROTECTION PROGRAM...............................29

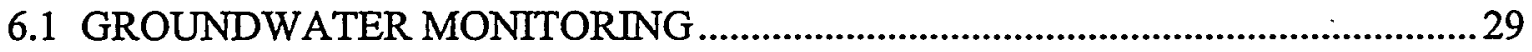

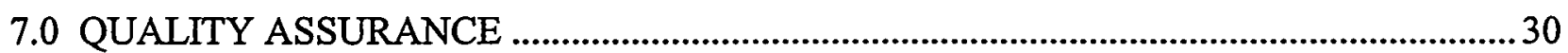

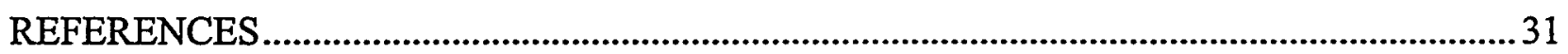

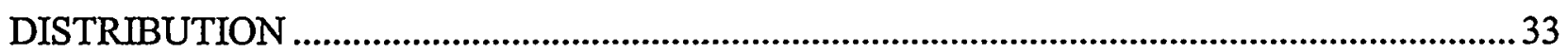

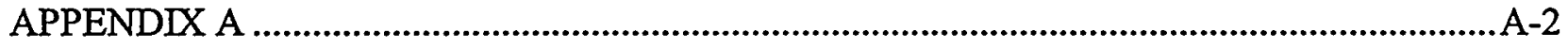

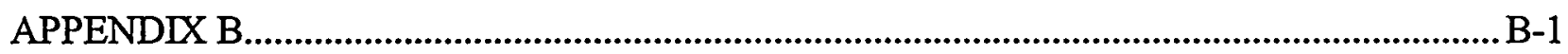

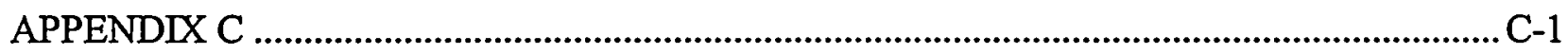

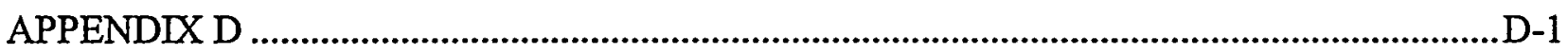




\subsection{INTRODUCTION}

The Western Area Power Administration (Western) was established on December 21, 1977, under Section 302 of Public Law 95-91, the Department of Energy Organization Act dated August 1, 1977. Western transmits Federal electric power to facilities in 17 Central and Western states encompassing a 1.3 million-square-mile geographic area (Figure 1).

Western operates and maintains nearly 17,000 miles of transmission lines, 256 substations, and various appurtenant power facilities in its service territory. Western is also responsible for planning, constructing, operating and maintaining additional Federal transmission facilities that may be authorized in the future. The electric power marketed by Western is generated by the U.S. Bureau of Reclamation (Reclamation), the U.S. Army Corps of Engineers (Corps), and the U.S. Section of the International Boundary and Water Commission (IBWC). Western markets power from 56 hydroelectric power generating plants in its service area. Additionally, Western markets the United States entitlement from the Navajo coal-fired power plant near Page, Arizona. The maximum operating capability that Western currently markets is more than 10,500 megawatts (MW). In Fiscal Year 1999, Western sold more than 45-billion kilowatt hours (kWh) of electricity to more than 600 wholesale power customers which generated more than $\$ 720$ million in revenues. These customers include rural cooperatives, municipalities, public utility districts, Federal and State agencies, irrigation districts, and project use customers. Wholesale power customers in Arizona, California, Colorado, Iowa, Kansas, Minnesota, Montana, Nebraska, Nevada, New Mexico, North Dakota, South Dakota, Texas, Utah and Wyoming, in turn, provide service to millions of retail consumers.

Western's major organizations include a Corporate Services Office (CSO) located in Lakewood, Colorado; four Regional Customer Service Offices located in Billings, Montana; Phoenix, Arizona; Loveland, Colorado; and Folsom, California; and the Colorado River Storage Project Management Center, located in Salt Lake City, Utah. Figure 1 shows the Western marketing area and duty stations. Through its power marketing and transmission program, Western secures revenues to meet the annual costs of operating and maintaining transmission facilities, purchased power, wheeling, and other expenses. Western is required to repay within allowable time periods, all the power investment plus interest, as well as, the portion of the Government's irrigation investments beyond the water users repayment capability. 


\section{Western Area Power Administration \\ DUTY LOCATIONS}

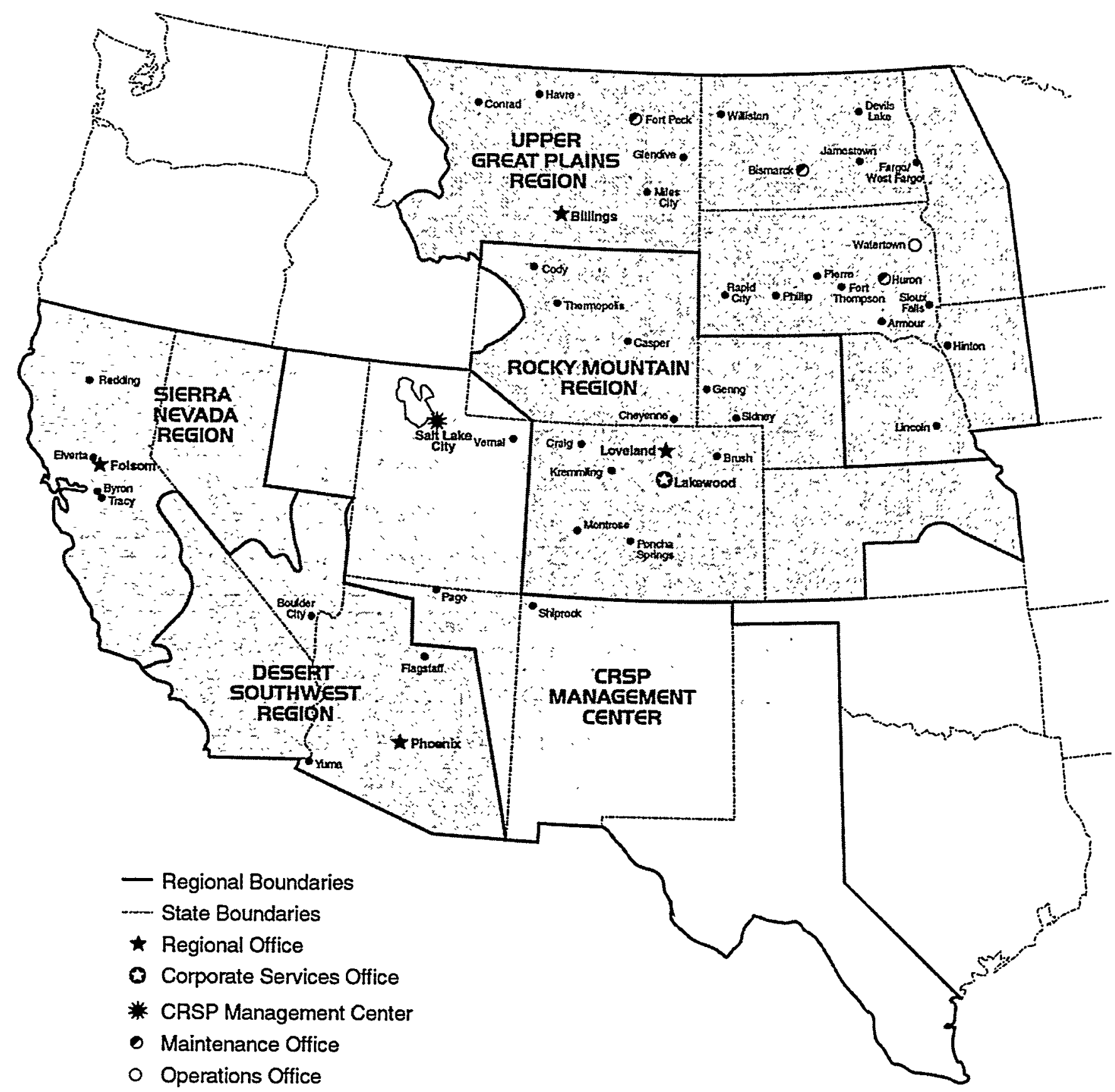

- Duty Station
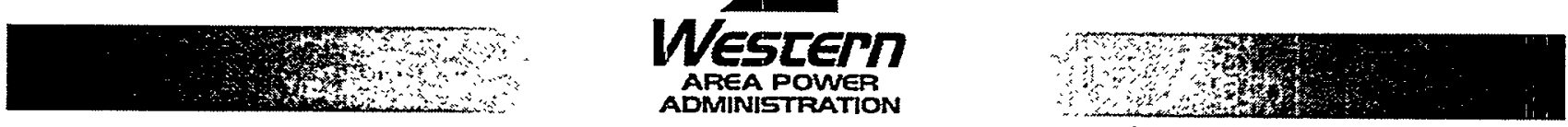

Figure 1 


\section{$2.0 \quad$ SUMMARY}

Many State and Federal environmental protection laws and regulations apply to Western. Western facilities are within the jurisdiction of six Environmental Protection Agency (EPA) regions and 17 states. Western's environmental policy statement directs employees to prevent, control, and abate environmental pollution at their facilities, and when possible, enhance the environment. To help assure conformance with all regulatory requirements, and to achieve its pollution prevention goals and objectives, Western is developing an Environmental Management System (EMS).

One of the major regulatory impacts on Western continues to be the Toxic Substances Control Act (TSCA) that regulates the use of polychlorinated biphenyls (PCB). Western's policy is to eliminate PCBs from its system wherever economically and operationally possible. This will lessen the impact of $\mathrm{PCB}$ regulations on operations and the impact of PCBs on the environment.

Executive Order 12856 requires Federal Agencies to comply with the Emergency Planning and Community Right-to-Know Act (EPCRA). As with other DOE elements, Western has been complying with EPCRA since before the Executive Order was issued. To summarize, in 1999, Western's Regional offices implemented programs to notify State and local emergency response entities in accordance with Section 311 and 312 of EPCRA. Chemical inventories indicate that Western does not manufacture, process, or otherwise use reportable quantities of EPCRA Section 313 chemicals so Toxic Release reports were not required.

Despite a 1996 report by the National Academy of Sciences indicating no known relationship between health effects and electric and magnetic fields (EMF), EMF remains a concern in the decision-making process under the National Environmental Policy Act (NEPA). Western continues to monitor the research efforts underway in these areas.

Throughout 1999, Western's environmental planning process has included early public and agency involvement in proposed projects. This, along with early internal scoping of environmental issues, helps to identify potentially significant impacts.

Western determines the appropriate level of environmental documentation through its policy of pre-scoping, and public and agency participation in project development. 
DOE Order 450.1A delegated Western the authority to approve its own environmental assessments (EA) as part of its NEPA program. In September 1998, Western was delegated cooperating agency determination authority which allows the Administrator to adopt Environmental Impact Statements (EIS) where Western is a cooperating agency. Three Regional Managers and the CRSP Manager have been delegated the authority to approve their own EAs. These authority delegations have shortened the environmental process and provided for project decisions to be made closer to the project level.

Large scale projects and projects with a high potential for significant environmental impacts are analyzed within the framework of EAs and EISs. With appropriate planning and mitigation, most Western projects result in minimal environmental impacts.

In 1999, new regulations for the National Historic Preservation Act changed the way Western consults with the State Historic Preservation Officers and the Advisory Council on Historic Preservation. Designation of several tribes as Tribal Historic Preservation Officers will require Western to consult with them on projects located on tribal lands.

In 1999, Western joined 17 other electric utilities on the Avian Power Line Interaction Committee (APLIC). APLIC was formed in 1988 to address the issue of bird collisions with transmission lines. Since then, they have developed training and manuals for reducing collisions and preventing bird electrocutions.

\subsection{COMPLIANCE SELF-ASSESSMENT}

\subsection{COMPLIANCE STATUS}

Western complies with environmental and other requirements established by Federal, State, and local statutes and regulations, Executive Orders, Department of Energy Orders, and agreements with Federal, State, and local regulatory agencies. The following paragraphs summarize Western's compliance status with the major environmental statutes.

\subsubsection{Resource Conservation and Recovery Act (RCRA)}

Since 1984, many regulations have been proposed or finalized as a result of the Hazardous and Solid Waste Amendments of 1984 (HSWA). HSWA-based 
regulations impact most Western facilities, which are classified as conditionally exempt small quantity generators of hazardous waste. HSWA also impacts Western operations by prohibiting the land disposal of hazardous wastes and setting standards for used oil management, underground storage tanks, and recycling hazardous wastes.

Negotiations continue with some states to increase action levels for soil cleanup involving non-PCB mineral insulating oils. Requests are made where increased cleanup levels are risk justified and would pose no threat to human health or the environment.

\subsubsection{Underground Storage Tanks (UST)}

California requires the annual renewal of permits to operate underground storage tanks. Colorado requires annual registration of all petroleum USTs. By monitoring and updating of permits, Western continued to comply with State underground storage tank regulations during 1999.

Western is in compliance with the EPA's UST upgrade and monitoring requirements deadline of December 22, 1998.

\subsubsection{Toxic Substances Control Act (TSCA)}

Western continued the removal and proper disposal of mineral oil dielectric fluid (MODEF) and PCB equipment from facilities during 1999. Each Regional Office manages its own PCB transportation and disposal contracts. Waste transporters and treatment, storage, and disposal facilities are audited prior to contract award. Contractors are required to transport and dispose of the PCBs and prepare all necessary paperwork, including certificates of destruction or disposal.

Removal and disposal of PCB equipment throughout Western continued in 1999 with several large-scale removal and upgrade projects. Low level PCB contaminated oils were burned for energy recovery at EPA-permitted facilities or were chemically treated and recycled. Higher concentration PCBs were disposed of at EPA-certified incinerators. Contaminated equipment carcasses were 
decontaminated and sold as scrap when possible. Items too heavily contaminated for recycling as scrap were disposed of at chemical waste landfills or were incinerated at permitted facilities. More than 10,000 gallons of oil with various levels of PCB contamination were removed from service. Nearly 200 tons of metals and over 20,000 gallons of non-PCB oil were recycled.

Western added formality to the TSCA program by forming a Western-wide PCB coordination group. This group drafted the Western PCB Management Plan. The Plan is scheduled to be finalized in mid- 2000 .

\subsubsection{Comprehensive Environmental Response, Compensation, and Liability Act (CERCLA)}

\subsubsection{Superfund Amendments and Re-authorization Act (SARA)}

Since SARA was passed in 1986, to amend CERCLA, 23 Western facilities have been placed on the Federal Agency Hazardous Waste Compliance Docket (Docket). The Docket is a list of facilities under Federal control which have the potential for environmental releases which could adversely affect human health or the environment. Fourteen facilities listed were deleted from the Docket in 1991. Seven of the remaining nine have been given "No Further Remedial Action Planned" (NFRAP) or "Site Evaluation Accomplished" status. The other two were deleted from the Docket in 1999.

Western was proactive by implementing a Facility Evaluation Program to comply with Section 120(b) of CERCLA. The purpose of this program is to evaluate all Western facilities for sources of and suspected releases of oil, hazardous substances, pollutants, or contaminants into the environment. The evaluations continued in 1999 with three facility evaluations accomplished at sites that Western is proposing for transfer or acquisition in accordance with Section 120(h) of CERCLA. 


\subsubsection{Emergency Planning, Community Right-to-Know Act (EPCRA)}

Western conducts annual inventories of chemicals at facilities throughout its service area. The information gathered is used to prepare the Section 311 and/or 312 reports to State and local emergency response entities. In 1999, Western submitted Tier II reports on more than 100 facilities. These inventories are also used to verify that Western does not manufacture, process, or otherwise use threshold quantities of any of the chemicals identified in Section 313 of EPCRA and does not report under that Section. However, EPA's proposed addition of persistent bio-accumulative toxics, such as PCBs and mercury, may require Western to prepare Section 313 reports in the future.

\subsubsection{Federal Insecticide, Fungicide, and Rodenticide Act (FIFRA)}

Western is required to comply with the pesticide use, storage, and disposal regulations contained in FIFRA, individual State, and some tribal pesticide management regulations. Pesticides are used by Western to control plant and animal pests, and for wood preservation.

Western's Corporate Services Office Environmental Office prepared and distributed two manuals, the "Integrated Vegetation Management Environmental Guidance Manual" and the "Pest Control Manual," during January of 1996. These manuals were revised and updated in 1999 due to additional pesticide products on the market, changes in regulations, new information, and Regional requests. Sections of both manuals have been updated with the latest information for integrated vegetation management and pest control techniques. The updated manuals were distributed in 1999. The Vegetation Management Manual is also available for viewing on the Western web site <www.wapa.gov/cso/cpo/enviro/default.htm>. In addition, the Pest Control Manual will be accessible on the environmental management web site in early 2000 .

Western's integrated vegetation management (IVM) program promotes the use of combined methods to control unwanted vegetation. IVM combines biological, 
cultural, physical, and chemical tools to minimize economic, health, and environmental risks. IVM de-emphasizes the exclusive use of chemical control.

Western is assessing the impact of Executive Order 13112 "Invasive Species." With nearly 17,000 miles of right-of-way, control of non-native species could be problematic for the IVM program.

Methods in the manual promote establishing a stable, low-growing plant community on Western rights-of-way. Such a community is compatible with transmission lines, serves as an environmentally acceptable and useful ground cover, and naturally retards the re-growth of tall-growing vegetation. This minimizes the frequency of future right-of-way maintenance operations and reduces potential interruption of service.

In cooperation with the Platte River Power Authority and the Town of Estes Park, Colorado, Western will assess the effectiveness of two biological barriers in controlling weed growth at a local substation. These biological barriers are geotextile fabrics that either have been impregnated with herbicide nodules, or are coated with an anti-germination coating (such as copper hydroxide). They are placed under the gravel floors at substations and yards. These biological barriers inhibit the establishment of vegetation by creating a physical barrier that prevents the germination of seeds located under the membrane. In addition, they slowly release herbicides to control vegetation or prevent weed germination without the need for frequent application of chemical sprays or granules.

Western will continue to evaluate the use of tree growth regulators (TGRs) as a means of managing the growth of trees under transmission lines in urban settings. TGR's have been applied to deciduous trees at various localities within the service area. Agreements will be pursued with Federal land management agencies to establish TGR test plots to determine growth regulator efficacy and cost effectiveness in controlling growth of deciduous, as well as, evergreen trees. 
Western continued to enter into Interagency Agreements and County Cooperative Agreements to aid in the control of noxious weeds and to comply with State/county noxious weed management legislation.

\subsubsection{Clean Air Act (CAA)}

Several potential sources of air emissions exist at Western facilities that are regulated under the CAA. These emissions include dust during construction activities, friable asbestos during building renovation or demolition, and volatile organic compounds emissions from gasoline dispensing facilities. Western's construction specifications require practical methods and devices to control, prevent, and minimize emissions or discharges of air contaminants during construction activities. Particulate emissions from construction activities along access and haul roads are minimized by periodic watering of disturbed soils.

Regulatory requirements applicable to the disposal of asbestos and asbestoscontaining material affect Western when activities are planned to modify or demolish existing buildings. Western continued surveys initiated in 1988 to identify and quantify asbestos in its facilities. The results of these surveys indicated the presence of asbestos in four facilities. Western personnel notify all appropriate regulatory agencies when planning any renovation and demolition projects that might include asbestos. In addition to the Federal regulations, State and local laws and regulations are followed to assure proper disposal of asbestos containing material.

Executive Orders, EPA regulations, and an interim rule require Federal agencies to significantly reduce use, where practicable, of ozone-depleting substances. This is to be accomplished through cost-effective procurement practices, and through the substitution of safe alternative substances, and to provide leadership for their phaseout.

The phaseout of ozone-depleting substances affects Western's operations associated with refrigeration and air conditioning, fire protection, and solvent usage. Safe alternatives are being used instead of ozone-depleting chemicals to the extent 
practicable. Ozone-depleting substances are recovered in air conditioning and refrigeration systems and fire suppression systems before final disposal or dismantling of equipment. Technician certification is required for all individuals who maintain, service, repair, or dispose of appliances, equipment, and motor vehicle air conditioners (MVAC) containing Class I or Class II refrigerants. Facilities have either acquired approved recovery equipment and training for technicians, or contracted for such services that have EPA approval to comply with sections 608 and 609 of the CAA.

In accordance with "Guidance on the DOE Facility Phaseout of Ozone-Depleting Substances," requiring compliance with Executive Order 12843, Western identified present and future uses of ozone-depleting substances. The Corporate Services Office and most of the Regional Offices have phased out halon-containing hand held fire extinguishing equipment for all but a few uses. Several of the Regions have also phased out all halon-based fire suppression systems. These fire suppression systems and equipment were replaced with carbon dioxide and dry chemical extinguishers.

EPA invited Western, along with other electric utilities, to sign a Memorandum of Understanding (MOU) for reduction of $\mathrm{SF}_{6}$ gas emissions. Western has numerous pieces of $\mathrm{SF}_{6}$ gas-filled equipment. Western began evaluating organizational effects of signing the MOU, and anticipates a final decision in early 2000.

\subsubsection{Safe Drinking Water Act (SDWA)}

\subsubsection{Underground Injection Control (UIC)}

Western continues to cooperate with EPA regions and states to obtain permission to permanently close and abandon all Class V UIC wells as they are discovered.

\subsubsection{Re-authorization of the SDWA}

The re-authorization of the Safe Drinking Water Act (Safe Drinking Water Act Amendments of 1996) included two sections that affect Western's activities. First is the formalization of the requirement for Federal agencies 
that own or operate a facility in a wellhead protection area to conduct an evaluation of activities that result in underground injection. Federal agencies that are involved in other activities that contaminate, or threaten to contaminate water supplies, must comply with all Federal, State, interstate, and local requirements related to wellhead protection, underground injection, and public water supplies. Second is the provision to fund states for wellhead protection, critical aquifer and underground injection control programs, and grants for coordinated and comprehensive protection of groundwater resources. Emerging State programs and requirements related to those issues which may affect Western are being tracked.

\subsubsection{Clean Water Act (CWA)}

\subsubsection{Spill Prevention, Control, and Countermeasures Plans (SPCC)}

Western continues to evaluate facilities for the need for SPCC Plans, including secondary containment, at new or existing facilities. The purpose of the evaluations is to periodically review existing SPCC Plans for necessary revisions or updates, and to make recommendations to other entities with whom we share facilities, and thus regulatory compliance responsibilities at those facilities. Fifty-six SPCC Plans were written or revised, based on new site-specific information, construction or other modifications to the sites, or revised inventories of oil-filled equipment. Western's Sierra Nevada Region is combining SPCC Plans with its Hazardous Waste Business Plans.

\subsubsection{Other Clean Water Act Issues}

Western is using the Mineral Oil Spill Evaluation System (MOSES) software developed by EPRI to assist in determining the need for secondary containment and SPCC applicability at its facilities.

\subsubsection{Hazardous Materials Transportation Act (HMTA)}

Almost all of the hazardous and toxic material transported for Western is shipped by audited and permitted commercial hazardous materials haulers. However, trained and qualified Western employees occasionally transport hazardous materials. 
Hazardous materials transportation requirements for the California Department of Toxic Substances Control, North Dakota Department of Health, and Minnesota Pollution Control Agency are more extensive than those of the U.S. Department of Transportation (DOT). Therefore, the Sierra Nevada and Desert Southwest Regional Offices must have California waste haulers' permits to transport Polychlorinated Biphenyls. The Upper Great Plains Region maintains permits for hauling all solid waste.

Western Environment staff developed a training program in 1993, which addresses the requirements of Federal DOT HM (Hazardous Material)-181 to safely transport of hazardous materials. With emphasis on Western's operations, the program is updated on an annual basis. The training program is modeled after the DOE's Hazardous Material Modular Training Program developed in conjunction with U.S. DOT, Research and Special Programs Administration (RSPA), and the Office of Hazardous Materials Transportation.

\subsubsection{National Historic Preservation Act (NHPA)}

During 1999, Western initiated or continued previous cultural resource compliance efforts for 32 projects in seven states. The projects included mitigation, monitoring, and/or surveys to upgrade and maintain substations, microwave communication facilities, electrical transmission lines, and access roads. In accordance with Section 106 of the NHPA, as amended, Western solicited the comments of the State Historic Preservation Officers in seven states and one Tribal Historic Preservation Officer regarding these projects. In addition, Western consulted with 12 Indian tribes regarding projects in these states. This allowed Western to evaluate cultural resources within the proposed project areas and identify potential effects of the projects on significant cultural resources. Plans to mitigate potential project effects included avoiding, monitoring, testing, and excavation.

\subsubsection{Native American Graves Protection and Repatriation Act (NAGPRA)}

NAGPRA requires consultation with Indian tribes on repatriation issues. Western had no projects on Western fee-owned lands that required NAGPRA consultations. 


\subsection{CURRENT ISSUES}

In August 1998, US EPA Region VIII conducted an Environmental Management Review of the Corporate Services Office and the Rocky Mountain Region. The reviewed topics were "Environmental Commitment" and "Formality of Environmental Programs." Western received the final report in November 1998. Six "Suggested Actions" were included in the report. Western provided written feedback in May 1999 on progress taken to address the suggested actions. A follow-up meeting was held with EPA in December 1999.

\subsubsection{Other Environmental Issues}

\subsubsection{Lead Paint Management Program}

Many of Western's facilities were built in the 1940s, 1950s, and 1960s and they may contain lead-based paint. Regional Environment staff throughout Western have continued to obtain training in management of, and surveys for, lead-based paint. The paint is either managed in place, or removed for disposal.

\subsubsection{Asbestos Management Program}

Several states in Western's service area have drafted laws increasing the need for asbestos surveys in Western's older buildings. In 1999, Regional Environment staff continued asbestos surveys in all buildings. The material is removed for disposal or managed in place. Several Western environmental staff members are certified for asbestos management.

\subsection{SUMMARY OF PERMITS}

Western is required to obtain a variety of permits, including those for above ground and underground storage tanks, PCB transportation and storage, hazardous waste storage, gasoline dispensing, underground injection wells and NPDES permits for point source and stormwater discharge. Table 1 lists the permits obtained or continued in 1999. 


\section{TABLE 1. LIST OF ENVIRONMENTAL PERMITS OBTAINED OR ONGOING DURING CALENDAR YEAR 1999}

\begin{tabular}{|c|c|c|c|}
\hline NAME & ISSUING AGENCY & STATUS & $\begin{array}{l}\text { EXPIRATION } \\
\text { DATE }\end{array}$ \\
\hline 404 Permit & Sher & 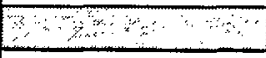 & 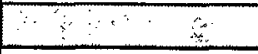 \\
\hline Nationwide & U.S. Army Corps & Ongoing & None \\
\hline General Permit 55 & U.S. Army Corps & Project specific & $12 / 31 / 00$ \\
\hline Devil's Lake-Lakota 115-kV & U.S. Army Corps & Renewal & $2 / 28 / 00$ \\
\hline Migratory Bird Treaty Act & 2. & 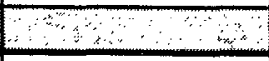 & \\
\hline Take osprey nests in Montana & U.S. Fish \& Wildlife Service & Ongoing & $07 / 31 / 00$ \\
\hline Hazardous Waste & 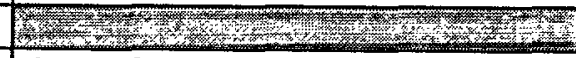 & 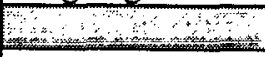 & \\
\hline Hauler Registration & State of CA & Renewed & Open \\
\hline Variance Application & State of CA & Obtained & Open \\
\hline Hazardous Waste hauling Permit & Minnesota Pollution Control Agency & Ongoing & Annual \\
\hline Transporter Permit & North Dakota Department of Health & Ongoing & $10 / 07 / 09$ \\
\hline Permit to Operate & 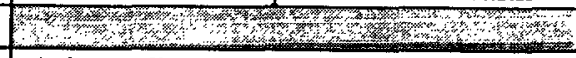 & bry & 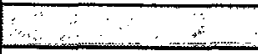 \\
\hline Underground Storage Tanks & $\begin{array}{l}\text { Arizona Department of } \\
\text { Environmental Quality }\end{array}$ & Ongoing & Annually \\
\hline & Colorado State Inspector of Oil & Ongoing & Annually \\
\hline Hazardous Materials Permit & 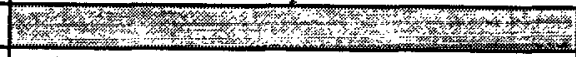 & 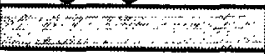 & \\
\hline Hazardous Materials Business Plans & Alameda County & Ongoing & Annually \\
\hline & Calavaras County & Ongoing & Annually \\
\hline & Colusa County & Ongoing & Annually \\
\hline & Contra Costa County & \begin{tabular}{|l|} 
Ongoing \\
\end{tabular} & Annually \\
\hline & Kern County & Ongoing & Annually \\
\hline & Merced County & \begin{tabular}{|l|} 
Ongoing \\
\end{tabular} & Annually \\
\hline & Sacramento County & Ongoing & \begin{tabular}{|l} 
Annually \\
\end{tabular} \\
\hline & San Joaquin County & Ongoing & \begin{tabular}{|l|} 
Annually \\
\end{tabular} \\
\hline & Santa Barbara County & Ongoing & Annually \\
\hline & Santa Clara County & Ongoing & \begin{tabular}{|l|} 
Annually \\
\end{tabular} \\
\hline & Shasta County & Ongoing & Annually \\
\hline & Tehama County & Ongoing & Annually \\
\hline & Trinity County & Ongoing & Annually \\
\hline Water Quality & 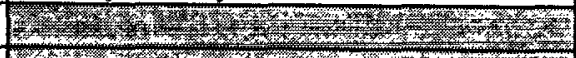 & 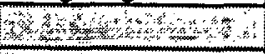 & 20 \\
\hline NPDES Permits & 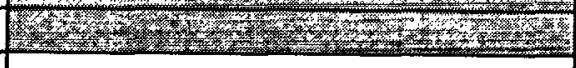 & 4 & 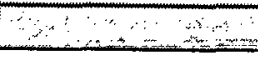 \\
\hline Clean Air Permits & 1 & 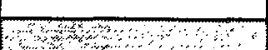 & w: \\
\hline Diesel Dispensing & 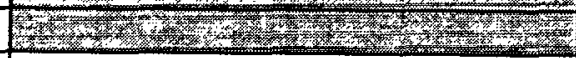 & 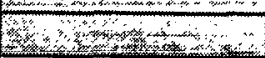 & 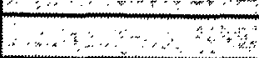 \\
\hline Facility Permit & $\begin{array}{l}\text { Sacramento Air Pollution Control } \\
\text { District }\end{array}$ & Ongoing & Annually \\
\hline Gasoline Dispensing & W & 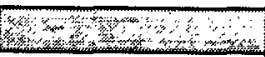 & 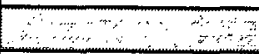 \\
\hline Facility Permit (CA) & $\begin{array}{l}\text { Sacramento Air Pollution Control } \\
\text { District }\end{array}$ & Ongoing & Annually \\
\hline
\end{tabular}




\subsection{ENVIRONMENTAL PROGRAM INFORMATION}

\subsection{ENVIRONMENTAL PROTECTION PROGRAMS}

\subsubsection{Environmental Management System (EMS)}

Changes in roles and responsibilities have evolved throughout Western. There are fewer environmental programs operated out of the Corporate Services Office. Roles and responsibilities have changed in the Regional Offices as well. In an effort to operate more efficiently and with the priority of continuous improvement, the agency is developing and implementing an Environmental Management System (EMS). Elements of the EMS will be applied by reviewing the results and implementing recommendations of a comprehensive self-assessment program. These self-assessments identify the status of Western's environmental programs, where gaps occur in program elements, and where formality is lacking. Western has completed assessments of the PCB Cultural and Historic Resources programs in 1998 and is incorporating corrective actions. In 1999, Western completed the assessments on the EPCRA, CERCLA, SARA, and RCRA management programs. Corrective actions identified in these self-assessments will be implemented in 2000 . Western initiated self-assessments on its NEPA, SPCC and storage tank programs in 1999.

\subsubsection{Emergency Planning, Community Right-to-know Act}

In 1990, the Secretary of Energy committed all elements of the Department of Energy to complying with the Emergency Planning, Community Right-to-Know Act (EPCRA), which is a part of CERCLA. Subsequently, Executive Order 12856 committed all Executive Agencies to comply with EPCRA. Western has completed chemical inventories in all of its facilities to determine if reporting requirements in the various sections of EPCRA are met. Based on these inventories, Western has determined that reporting is not necessary for EPCRA Sections 302-303, 304, and 313. In accordance with EPCRA Section 311-312, Western advises State and local emergency response entities of chemical inventories and their locations within the facilities every year. 


\subsubsection{Environmental Auditing Program}

Western established an environmental auditing program in 1980. The major purposes of the auditing program are:

- discover noncompliance with applicable local, State, and Federal regulations;

- reduce environmental risks;

- improve communication with facility personnel;

- improve overall environmental performance;

- provide assistance and discuss compliance alternatives for problem areas;

- accelerate development of good environmental management practices;

- ensure worker safety when working with hazardous materials; and

- provide management with a tool for evaluating the priority of compliance issues.

The purpose of Western's internal audit program is to advise facility and Regional management of the applicability of current regulations regarding their particular operations. The audits are also conducted to review records, point out areas of noncompliance, and identify practices that are at variance with industry environmental standards. The audit results are used to provide compliance assistance to the facilities.

In 1999, 115 Western facilities were audited by Western Environment staff. These internal functional appraisals were undertaken in accordance with WAPA Order 5400.2A and were frequently done in conjunction with joint safety and environmental reviews. Facilities audited included microwave sites, substations, maintenance facilities, and storage yards. Audit reports contain recommended actions the facility may adopt to improve compliance with the applicable regulations. 
Regulatory agencies, both Federal, State and local, conducted audits and inspections of Western's facilities in 1999. The Roseville Fire Department audited the Roseville Substation and Sacramento County conducted an audit of the Elverta Substation. In addition, the Corporate Service Office and the Rocky Mountain Regional Office continued to work with the EPA's Region VIII following the 1998 Federal Facility Environmental Management Review through meetings and written comments.

Western's Environment staff also conducted three external audits of its contractors and vendors. The purpose of these audits is to verify the vendor/contractor compliance with Federal, State, and local environmental laws and regulations. Those audits are listed below.

$\begin{array}{lllll}\text { DATE } & \text { FIRM AUDITED } & & \text { TYPE OF FIRM } & \text { TYPE OF AUDIT } \\ \text { April } & \begin{array}{l}\text { Tri-State Recycling } \\ \text { (Newcastle, WY) }\end{array} & \text { Used Oil Recycler } & \text { Compliance } \\ \text { April } & \begin{array}{l}\text { Interstate Battery } \\ \text { Systems }\end{array} & \text { Battery Recycler } & \text { Compliance } \\ \text { May } & \begin{array}{l}\text { (Fargo, ND) } \\ \text { Safety Kleen } \\ \text { (Kansas City, MO) }\end{array} & \text { PCB Recycler } & \text { Compliance } \\ & & & \end{array}$

\subsubsection{Long Range Environmental Plan}

The EMS discussed in Section 4.1.1 will replace the Long Range Environmental Plan and this Section will be deleted in future Annual Site Environmental Reports.

\subsubsection{Environmental Protection Compliance Information}

In 1999, Western continued to provide Crafts and Management staff with guidance and training on environmental protection and compliance. Information and summaries of specific regulations, statutes, and compliance issues are covered in non-legal terms, to enhance understanding. Advisories developed in Corporate Services Office during 1999 were provided as guidance on clean air requirements, underground storage tanks, spill prevention control and countermeasures plans, secondary containment, $\mathrm{SF}_{6}$ handling, and appropriate pesticide use. These advisories supplement the more formal notices (sent in the form of handbooks and memoranda) that are used to inform Regional Managers and their Environment staff 
of regulatory requirements. Regional Environment staff also provide advisories to staff and management throughout Western regarding local and regional issues.

These are sent out quarterly or monthly, depending on the region and the issues.

\subsubsection{Waste Minimization, Pollution Prevention and Affirmative Procurement}

In complying with DOE Order 5400.1, WAPA Order 5400.2A, and Executive

Orders $12780,12843,12856,12873$, and 13101, Western has developed a Waste

Minimization/Pollution Prevention Awareness Plan (Plan). This Plan provides

guidance to develop and implement a facility-wide, multimedia pollution prevention program within Western. Western's goal is to eliminate or reduce the generation of waste and associated adverse environmental impacts throughout Western, with primary emphasis on source reduction. This goal includes support of DOE's commitment to the requirements of Executive Order 12856, which establishes a National goal of reducing releases of CERCLA, Section 313 toxic chemicals, by 50 percent by December 31, 1999.

The specific activities necessary to meet the Plan goals include: 1) Conducting pollution prevention opportunity assessments on facilities and operations; 2) Incorporating pollution prevention considerations into the acquisition process (e.g. affirmative procurement of recycled materials); 3) Developing a pollution prevention ethic and pollution prevention awareness in the workplace; and 4) Annual reporting to DOE on the status of Western's Waste Minimization/Pollution Prevention Program, and evaluation of progress toward the Plan goals.

Pollution prevention is incorporated into existing training so that Plan goals, projects, and ideas are part of training curriculum or meeting agendas. Western employees who generate or handle waste, or recycle and reuse materials, are required to report this information to their respective Waste Minimization Assessment Team members. The annual report on waste generation and waste minimization progress will be submitted to DOE in March 2000.

As a major supplier of electric power, the work of the agency results in potentially toxic byproducts and generation of several types of wastes. Western's construction, 
demolition, and replacement activities generate large quantities of waste electrical equipment and scrap metal. Western reduces the amount of contaminants, wastes, and other regulated materials through source reduction and recycling programs. Since 1977, Western has reduced the use of PCBs and minimized waste generation through retro-filling equipment and processing to remove PCBs and reusing the oil. Although PCBs have not been completely eliminated, Western continues PCB removal and cleanup as they are found and budget considerations permit. Changes in EPCRA Section 313 regulations, regarding persistent bio-accumulative toxics, have added impetus to this removal. $\mathrm{SF}_{6}$ breakers have replaced oil-filled circuit breakers at several sites. The oil and metal from these replacements have been recycled as regulations allow.

Executive Order 13101, Greening the Government Through Waste Prevention, Recycling and Federal Acquisition, requires Federal agencies to purchase products listed by the EPA which contain post consumer recycled content materials. These affirmative procurement categories include paper products, construction materials, and non-paper office supplies.

An annual report is submitted to DOE for all listed non-GSA purchased products. GSA reports Western's purchases directly. In 1999, Western reported $\$ 971,443$ in purchases subject to affirmative procurement, of which $\$ 457,820$ contained recovered content materials. The two largest categories not meeting the full requirement were concrete and tires. Many concrete suppliers are unable to obtain power plant fly ash to add to their mixes. Tire suppliers are often unable to supply retreaded tires in the sizes needed to fit Western's equipment.

\subsubsection{Environmental Risk Assessment and Management}

Western has developed two environmental risk management assessment methods: 1) The Qualitative Issue Characterization (QuIC); and 2) The Semi-Quantitative Evaluation (SEQUEL). The QuIC approach is used to gather and structure the basic information needed to make decisions about environmental issues. The SEQUEL approach uses this information to evaluate and rank environmental risk issues and also to evaluate Western's ability to manage that risk. SEQUEL evaluates the 
environmental risk by assessing an issue's potential human and environmental impacts, regulatory impacts, business impacts, and public perception impacts. The ability to manage risk is based on an organization's environmental policies, human and financial resources, and its performance in the area of policy implementation. By comparing the risk score of an environmental issue with the score gaging the ability to manage risk, Western is able to identify imbalances and work toward . correcting deficiencies in our environmental management system.

The environmental risk assessment and management tools were used in 1999 to help decision-makers manage risk and prioritize activities.

\subsection{STATE AND LOCAL ENVIRONMENTAL REQUIREMENTS}

Western has facilities in 17 Western and Central states. Executive Order 12088 requires Federal agencies to comply with EPA and State and local environmental regulations. Examples of the regulations enforced at State and local levels include RCRA, community right-to-know, pesticide application, and storage tank regulations. Most of the states in Western's service area regulate the generation, transportation, treatment, storage, and disposal of hazardous and toxic materials. Community right-to-know legislation and hazardous waste clean-up laws, enacted by numerous states, are increasing the control of tracking hazardous and toxic materials.

Western cooperates with State and local environmental regulators and works toward complying with applicable laws, statutes, regulations, and ordinances. Environmental audits of Western facilities address applicable State requirements in addition to those imposed by the Federal government. Additionally, Western's Regional environmental staff have developed annual chemical inventory programs and provide CERCLA Section 311 and 312 reports to local emergency response entities.

\subsection{NEPA PLANNING SUMMARY}

In 1999, Western continued formal internal scoping and initiating external contacts with resource management and permitting agencies in the early stages of projects. The former ensures adequate and accurate purpose and need statements are incorporated in NEPA review, and the latter provides an effective and efficient means of assuring the 
consideration of sensitive environmental issues. Western prepared a new Interconnection Guidebook, which provides guidance to prospective energy developers on the business, engineering, and environmental requirements for connecting into Western's transmission system.

Western had 110 environmental planning projects either started or under way during Calendar Year (CY) 1999. Below are listed the EISs, EAs and CXs where Western was involved as the lead or a cooperating Federal Agency in 1999. These projects include interconnection requests, high-voltage transmission lines, repair or replacements, substation upgrades, power.marketing rate adjustments, and/or communications systems. The EISs for which Western is a cooperating agency are those that have the potential to affect hydropower generation or may affect Western's transmission system.

Buchanan Boulevard EA (DOE/EA-1999-154)

- EA Determination signed on

- $\quad$ EA on hold

Curecanti-Lost Canyon EA (DOE/EA-1287)

- EA Determination signed on January 8, 1998.

- Draft EA is expected to be complete in early 2000.

Sierra Nevada Region Vegetation Management EA - (DOE/EA-

- $\quad$ EA Determination signed on October 21, 1996.

- Draft EA internal review started in December, 1996.

- EA on hold pending Memorandum of Understanding with the U.S. Forest Service.

Calpine Sutter Power Plant EIS (DOE/EIS-0294)

- Received delegation of approval authority for an EIS on January 21, 1998.

- Published the Notice of Intent to prepare an EIS on February 13, 1998. 
- Issued the Draft EIS on October 30, 1998.

- Public hearings were held November 2 through December 1, 1998. This EIS was done in conjunction with the California Energy Commission.

- The final EIS was approved April 12.

- The ROD was signed May 25, and published June 15.

\section{Griffith Power Plant Project (DOE/EIS-0297)}

- Delegation of Authority was granted to Western for this project on March 17, 1998.

- Notice of Intent was published March 23, 1998.

- $\quad$ Draft EIS was published October 29, 1998.

- Public hearings were held December 8, 1998.

- The final EIS was issued March, 1999.

- The ROD was signed May 12, and published May 28, 1999.

Southpoint Power Plant Project (DOE/EIS-0308-SA-1 \& SA-2)

- The Bureau of Indian Affairs' draft EIS, was issued September, 1998,

- Cooperator status on the draft EIS was granted to Western November 24,1998.

- The first Supplement Analysis was completed March 16, 1999.

- Western's ROD was published April 1, 1999.

- A second Supplement Analysis of the EIS is being prepared to determine if expanding the ROW from Topock to the Southpoint Power Plant will require a Supplemental EIS.

- A determination is expected in early 2000.

Central Valley Project Improvement Act EIS: 
Western's Sierra Nevada Regional Office is a cooperating agency on the Central Valley Project Improvement Act (CVPIA) EIS, with the U.S. Fish and Wildlife Service, and the U.S. Bureau of Reclamation. Western reviewed the Administrative Draft EIS and provided comments to the Interior agencies in May 1997, regarding the document's ability to meet the requirements of NEPA and its technical adequacy as a decision document. Western was asked to provide a technical review of the Draft EIS in November 1997, and provided comments back to the Department of the Interior in April 1998. The project was delayed several months due to an error in the water modeling software.

\section{CALFED Bay/Delta Program EIS:}

Western's Sierra Nevada Regional Office is a cooperating agency on the CALFED Bay/Delta Program EIS. There are 13 State and Federal agencies involved in this project. The preliminary draft EIS/EIR was issued in March 1998. A Phase II report describing the preferred alternative and issues to be resolved (including hydropower impacts) was released in December 1998.

\section{Trinity River Fisheries EIS:}

The Sierra Nevada Regional Office is a cooperating agency for the Trinity River Fisheries EIS. The Department of the Interior also has the lead on this EIS. The EIS addresses flow levels in the Trinity which could affect Western's hydropower resource.

\section{Platte River Cooperative Agreement EIS:}

The U.S. Fish and Wildlife Service, and the Bureau of Reclamation are preparing an EIS on the Platte River Cooperative Agreement with the States of Colorado, Wyoming and Nebraska. Western's Rocky Mountain Region has requested and been granted authority to be a cooperating agency on this EIS. The Interior agencies are developing proposals for public review.

\section{Hoover Dam Bypass EIS:}


The Federal Highway Administration is preparing an EIS on a highway, which will bypass Hoover Dam on the Colorado River along the Nevada/Arizona border. The draft EIS, issued in September 1998, indicated that a number of Western's lines and/or switchyards would have to be relocated. Based on the draft, Western requested to be a cooperating agency from the Federal Highway Administration on November 27, 1998.

Eighty-eight projects were categorically excluded from further NEPA documentation in 1999 based on Subpart D of 10 CFR 1021. These projects are listed in Table 2.

TABLE 2. ENVIRONMENTAL PLANNING PROJECTS ONGOING OR COMPLETED IN CALENDAR YEAR 1999

\begin{tabular}{|l|c|}
\hline \multicolumn{1}{|c|}{ PLANNING PROJECTS } & CLEARANCE \\
\hline CATEGORICAL EXCLUSIONS & $6 / 99$ \\
\hline Energy Planning and Management Program Marketing CX & $10 / 99$ \\
\hline Henderson Switching Station Re-grading Project (CX) & $8 / 99$ \\
\hline Black Mesa Substation CX & $10 / 99$ \\
\hline Hilltop Substation CX & $11 / 99$ \\
\hline Parker-Blythe \#2 Hazard Tree Removal CX & \\
\hline Four Corners Microwave Fiber Optics Project CX & \\
\hline Mexican Hat Microwave Site Access Road Gate Repair CX & \\
\hline Lolami Point Microwave Access Road Relocation CX & $6 / 99$ \\
\hline North Havasu City Substation CX & \\
\hline Headgate Rock Substation Expansion CX & \\
\hline Spookhill Transmission line Relocation CX & \\
\hline Del Bac/I-19/Valencia Road Structure Relocation CX & \\
\hline Saguaro-Tucson ROW Clearing CX & \\
\hline Mead Substation Modification CX & \\
\hline Maricopa-Saguaro Maintenance CX & \\
\hline Liberty-Coolidge ROW Clearing CX & $3 / 99$ \\
\hline Amargosa Substation Modification CX & $2 / 99$ \\
\hline Parker-Blythe \#1 Transmission Line Tree Removal CX & $9 / 99$ \\
\hline Nogales Tap Substation Expansion CX & $3 / 99$ \\
\hline Blythe Substation Bay Rehabilitation CX & $12 / 99$ \\
\hline Parker-Blythe \#2 Emergency Pole Replacement CX & \\
\hline Tower Mountain Communication Site Maintenance CX & $6 / 99$ \\
\hline Tucson-Apache Emergency Re-conductoring CX & $8 / 99$ \\
\hline Wellton-Mohawk Substation Expansion CX & $2 / 99$ \\
\hline Pinnacle Peak Communication Site Maintenance CX & $8 / 99$ \\
\hline Gila-Wellton-Mohawk Crossarm Replacement CX & $4 / 99$ \\
\hline Glen Canyon Substation-Communication Site Fiber Optics CX & $3 / 99$ \\
\hline Hoover-Mead \#6 Marker Ball Placement CX & $11 / 99$ \\
\hline Parker-Davis \#2 Fiber Optic Cable Repair CX & \\
\hline Four Corners Power Plant-Microwave Fiber Optics CX & \\
\hline Gila Substation Expansion CX & \\
\hline & \\
\hline & \\
\hline & \\
\hline & \\
\hline & \\
\hline & \\
\hline & \\
\hline & \\
\hline & \\
\hline & \\
\hline & \\
\hline & \\
\hline & \\
\hline & \\
\hline & \\
\hline & \\
\hline & \\
\hline
\end{tabular}




\begin{tabular}{|c|c|}
\hline PLANNING PROJECTS & CLEARANCE \\
\hline Gila-Yuma Equipment Pole Fence CX & $9 / 99$ \\
\hline Davis-Kingman Re-alignment $\mathrm{CX}$ & $12 / 99$ \\
\hline Parker-Davis \#2 Emergency Re-conductoring CX & $2 / 99$ \\
\hline Boulder Canyon Rate Adjustment CX & $7 / 99$ \\
\hline \multicolumn{2}{|l|}{ Curecanti-Poncha Access Road Maintenance CX } \\
\hline Casper Service Center CX & $1 / 99$ \\
\hline Gore Pass-Muddy Pass Access Road Maintenance CX & $1 / 99$ \\
\hline Wyoming Area Tap lines CX & $1 / 99$ \\
\hline Bayard Tap Line CX & $1 / 99$ \\
\hline \multicolumn{2}{|l|}{ Gering-Stegall North and South Access Road Maintenance CX } \\
\hline Ralston Substation Expansion CX & $6 / 99$ \\
\hline Pueblo Substation Land Disposal CX & $7 / 99$ \\
\hline \multicolumn{2}{|l|}{ Glen Canyon-Shiprock Maintenance CX } \\
\hline Glendo-Podolak Conductor Repair CX & $7 / 99$ \\
\hline \multicolumn{2}{|l|}{ Glendo-Stegall North and South Access Road Maintenance CX } \\
\hline Lovell-Thermopolis Pole Replacement CX & $7 / 99$ \\
\hline Curecanti-Rifle Access Road Repair CX & $7 / 99$ \\
\hline \multicolumn{2}{|l|}{ Prospect Valley-Prospect Valley Tap Pole Replacement CX } \\
\hline Cheyenne-Miracle Mile \#1 Structure Protection Measure CX & $11 / 99$ \\
\hline \multicolumn{2}{|l|}{ Blue River-Summit Pole Replacement CX } \\
\hline Vernal Area Access Road Maintenance CX & $3 / 99$ \\
\hline \multicolumn{2}{|l|}{ Lovell-Yellowtail Wood Pole Replacement CX } \\
\hline Laurel Road Line Relocation Project CX & $3 / 99$ \\
\hline Tracy-Tesla Access Road Maintenance CX & $3 / 99$ \\
\hline Kile Road Hazard Tree Removal CX & $4 / 99$ \\
\hline Cottonwood-Roseville Tree Removal CX & $6 / 99$ \\
\hline Elverta Substation Contol Room CX & $11 / 99$ \\
\hline Trinity-Carr-Keswick/Springcreek Fiber Optic Project CX & $10 / 99$ \\
\hline East Contra Costa Irrigation District Interconnection & $8 / 99$ \\
\hline Tracy-Contra Costa-Ygnacio 69-kV Relocation & $3 / 99$ \\
\hline Devaul Substation Maintenance CX & $2 / 99$ \\
\hline West Fargo Substation Maintenance CX & $2 / 99$ \\
\hline Leed Communication Site Maintenance CX & $2 / 99$ \\
\hline Maryville Communication Site Maintenance CX & $2 / 99$ \\
\hline Washburn Substation Maintenance CX & $4 / 99$ \\
\hline Summit Substation Maintenance CX & $4 / 99$ \\
\hline Tyndall Substation Maintenance CX & $4 / 99$ \\
\hline Flandreau Substation Maintenance CX & $5 / 99$ \\
\hline Brinsmade Substation Maintenance CX & $5 / 99$ \\
\hline Fargo Substation Maintenance CX & $5 / 99$ \\
\hline Sioux Falls-Split Rock Interconnection CX & $5 / 99$ \\
\hline Fort Thompson-Big Bend Fiber Optics Project CX & $10 / 99$ \\
\hline Oahe-Fort Thompson Fiber Optics Project CX & $10 / 99$ \\
\hline Oahe-Midland Fiber Optics Project CX & $10 / 99$ \\
\hline Valley City Substation Maintenance CX & $8 / 99$ \\
\hline Forman Substation Maintenance CX & $8 / 99$ \\
\hline Armour Substation Maintenance CX & $8 / 99$ \\
\hline Pierre Substation Maintenance CX & $8 / 99$ \\
\hline Rapid City Substation Maintenance CX & $8 / 99$ \\
\hline Rugby Substation Maintenance CX & $9 / 99$ \\
\hline Granite Falls Substation Maintenance CX & $8 / 99$ \\
\hline Watertown Operations Office Maintenance CX & $9 / 99$ \\
\hline
\end{tabular}




\begin{tabular}{|l|c|}
\hline \multicolumn{1}{|c|}{ PLANNING PROJECTS } & CLEARANCE \\
\hline Jones Creek Communication Site Maintenance & $8 / 99$ \\
\hline Jamestown-Fargo Foundation Replacements CX & $9 / 99$ \\
\hline Bismarck-Jamestown Flood Maintenance Projects CX & $11 / 99$ \\
\hline Sioux Falls Service Center Maintenance CX & $9 / 99$ \\
\hline Dogden Butte Communications Site Maintenance & $11 / 99$ \\
\hline Buford-Trenton Rebuild CX & $5 / 99$ \\
\hline Fort Peck Storage Yard Expansion & $5 / 99$ \\
\hline Havre-Rainbow Access Road Improvements & $5 / 99$ \\
\hline City of Pierre Interconnection & \\
\hline Alliance Pipeline Tap & \\
\hline Cando Tap & \\
\hline Havre-Shelby Pole Replacement & $4 / 99$ \\
\hline Willow Lake Flood Maintenance Project & $11 / 99$ \\
\hline
\end{tabular}

\subsubsection{Future NEPA Actions}

Western expects to start the NEPA process for two interconnection projects in the next 12 months. The level of NEPA documentation has not yet been determined for these projects.

Western will request cooperating agency status for two more Interior Department EISs that are expected to start up in the Colorado River Basin in the next 12 months. These will cover the operation of the Flaming Gorge Dam and operation of the Aspinall Units. Additionally, the Sierra Nevada Regional Office will be a cooperating agency on the Madera Ranch EIS that is anticipated to start up in 2000.

With changes in the utility industry under way, including further deregulation, the open access requirements of the Energy Policy Act of 1992, and the proliferation of merchant power plants, Western anticipates four additional requests for interconnections in the next 24 months. Typically, the NEPA documentation for these requests will need to be fast paced, will have little lead time, and will be labor intensive, costing approximately $\$ 300,000$ to $\$ 500,000$ each. No specific schedule or cost information is available at this time. 


\subsubsection{Mitigation Activity}

Western's list of standard mitigation measures (Appendix A) accompanies all transmission line environmental documents. This list has been developed over the years to ensure compliance with the NEPA, the Council on Environmental Quality guidelines, the Endangered Species Act, and the National Historic Preservation Act among others. These measures are based on Western's experience with impacts associated with transmission line construction, operation, and maintenance.

Mitigation Action Plans were in place for the Sutter, Griffith, and the Southpoint Power Plant projects. These are provided as Appendices C, D and E, respectively. Additionally, Western continued monitoring previous mitigation actions in 1999, particularly of the Valley Elderberry Longhorn Beetle Habitat Restoration in the Sacramento Operations Center compound. This is reported in Appendix B. Other mitigation activities undertaken during CY 1999 are listed below.

- $\quad$ Surveyed for the boreal toad and Preble's meadow jumping mouse in

Colorado; birds of prey, vernal pools, and Valley Elderberry Longhorn Beetles in California; birds of prey in Arizona, Colorado, Utah; and various endangered, threatened, or sensitive plants in Arizona, California, Colorado, Nevada, New Mexico, and Utah.

- Reconstructed vernal pools (wetlands) were monitored in California to prevent encroachment and damage from the landowner's cattle. Requirements were to replace 2.92 acres. Western is currently showing approximately 3 acres as successful habitat.

- Surveyed transmission line crossings of wetlands in North and South Dakota to minimize impacts of routine maintenance activities.

- Monitored the osprey nests relocated in Montana, California, and Wyoming to reduce the potential for outages on the lines and the potential for electrocution of nesting birds. Western also monitored nests relocated in previous years.

- Monitored a bald eagle nesting platform constructed in Montana in1999. 


\subsubsection{Research}

Western participated in at least one research program dealing with environmental planning in each Regional Office. Among these is the Colorado River Endangered Fish Species Recovery Program for both upper and lower reaches of the river. For these programs, Western provides program review of the ecological studies of threatened and endangered fish that occur in the Colorado River. The Upper Great Plains Region has joined the Missouri River Basin Association. Western is participating on three subcommittees (i.e. Wildlife Subcommittee, Terns and Plover Subcommittee, and the Fish Subcommittee) of the Missouri River Natural Resource Committee, which is studying several bird and fish species which occur in the Missouri River Basin and which are listed as endangered or threatened. Upper Great Plains Environmental staff are assisting with the research undertaken by the Upper Missouri River/Yellowstone River pallid sturgeon workgroup. Western is participating in the CALFED Bay/Delta Ecosystem Restoration Program Plan, and has been asked to participate in the Platte River Cooperative Recovery Program.

Western is coordinating a diverse group of agencies, environmental organizations, and individuals in preparing a video on protecting birds of prey on electrical equipment. This video is expected to be available in 2000 .

Western also has personnel serving on the Western Systems Coordinating Council Environmental Committee, the Mid-Continent Area Power Pool, American Public Power Association Environmental Committee, the American Society for Testing and Materials Environmental Auditing Committee, the Electric Power Research Institute's (EPRI) Environmental Research Oversight Committee, and the Avian Power Line Interaction Committee. Western is participating with EPRI in evaluating substation and service center stormwater runoff for regulated pollutants. During the 1999 season, remote and automated sampling systems were developed. Should pollutants be found, treatment methods will be evaluated.

Western will participate with EPRI on developing and using laser-based $\mathrm{SF}_{6}$ leak detection equipment. The participation will help in further development of the 
technology while providing valuable information to Western on $\mathrm{SF}_{6}$ leaks so they may be repaired.

Under a 1995 MOU, the Upper Great Plains and Rocky Mountain Regions are cooperators with the Bureau of Reclamation and the Montana Department of Fish, Wildlife, and Parks investigating dissolved gas and fishery habitat issues in the Bighorn River below the Yellowtail Afterbay Dam. Plans are to continue with the cooperative research efforts and extend the MOU for an additional five years.

\subsection{ENVIRONMENTAL MONITORING INFORMATION}

\subsection{UNPLANNED RELEASES}

Several separate hazardous/toxic material spill incidents were reported. These spills were cleaned up as required by TSCA, RCRA, or the CWA, and the spills resulted in insignificant environmental damage. The locations and materials spilled are listed below:

TABLE 3. LIST OF HAZARDOUS MATERIAL RELEASES DURING CALENDAR YEAR 1999.

\begin{tabular}{|l|l|l|}
\hline FACILITY & STATE & RELEASED SUBSTANCE \\
\hline Shelby Substation & MT & 20 gallons of non-PCB transformer oil \\
\hline Virginia Smith Converter Station & NE & 50 gallons oil of non-PCB oil \\
\hline Loveland PMOC & CO & $<5$ gallons oil \\
\hline Rolla Substation & ND & $<5$ gallons of non-PCB oil \\
\hline Bismarck Substation & ND & $100-200$ gallons of non-PCB oil \\
\hline Miles City Converter Station & MT & $<15$ gallons of ethylene glycol \\
\hline Yankton Swithchyard & SD & 2,500 gallons of non-PCB oil \\
\hline Morris Substation & MN & 50 gallons of non-PCB oil \\
\hline Loveland PMOC & CO & $\begin{array}{l}75 \text { gallons of sulfuric acid released into } \\
\text { secondary containment }\end{array}$ \\
\hline
\end{tabular}

\subsection{GROUNDWATER MONITORING AND PROTECTION PROGRAM}

\subsection{GROUNDWATER MONITORING}

Western is developing an integrated, risk-based groundwater protection management program to protect and management of both groundwater quality and quantity. Western's program is being developed in accordance with DOE draft groundwater protection guidelines. A groundwater monitoring plan, as required by DOE Order 5400.1, is part of the program. Groundwater protection management requirements had previously been 
incorporated into other programs, which inherently involve groundwater protection, such as for underground storage tanks, underground injection control, and solid waste disposal. Compliance with Federal, State, and local regulations is an integral part of all Western programs.

There was no groundwater monitoring reported at Western facilities for CY 1999.

\subsection{QUALITY ASSURANCE}

The current quality assurance policy for Western has been established in Western Order 5700.1 and DOE414.1A. It is Western's policy that, in the areas of Environmental compliance, safety, and health, quality requirements shall be established consistent with DOE Orders. Western is responsible for the overall quality of compliance with relevant Environmental laws and regulations. Regional Managers are responsible for the quality of activities in their own geographical areas. Due to the nature of Western's operations, an independent data verification program has not been established. Independent laboratories are used to analyze samples taken by Western or its contractors, and the laboratories used are certified when required by Federal, State or local regulations. Western irregularly audits these laboratories, using split sampling and similar techniques to test the accuracy of their data. An independent data verification program will be established on a project specific basis if required by the regulatory agency involved.

A Quality Assurance Program Plan (QAPP) has been developed to outline the policies, objectives, concepts, systems, and procedures for Western as required by DOE Order 414.1A. The implementation of the QAPP will provide credibility for environmental projects and ensures the generation of legally defensible data. 


\section{REFERENCES}

Cleàn Air Act

Clean Water Act

Code of Federal Regulations

Comprehensive Environmental Response Compensation and Liability Act

Department of Energy Organization Act of 1977 (Public Law 95-91)

DOE Order 224.1

DOE Order 231.1

DOE Order 414.1A

DOE Order 450.1 (draft)

DOE Order 451.1A

DOE Order 5400.1

DOE Order 5484.1

Endangered Species Act of 1973 (16 U.S.C. 1531 et seq.)

Emergency Planning Community Right-To-Know Act

Executive Order 12088

Executive Order 12843.

Executive Order 12856

Executive Order 12873

Executive Order 13101

Executive Order 13112

Federal Facilities Compliance Act

Federal Insecticide, Fungicide, and Rodenticide Act

Federal Water Pollution Control Act

Fish and Wildlife Coordination Act (16 U.S.C. 661-666c)

Hazardous and Solid Waste Amendments of 1984

National Environmental Policy Act of 1969 (42 U.S.C. 4321-4347)

National Historic Preservation Act of 1966, as Amended (16 U.S.C. 470)

Native American Graves Protection and Repatriation Act (25 U.S.C. 3001)

Pollution Prevention Act 
Resource Conservation and Recovery Act

Safe Drinking Water Act

Superfund Amendments and Re-authorization Act of 1986

Toxic Substances Control Act

Western Area Power Administration Order 5400.1A

Western Area Power Administration Order 5400.2A

Western Area Power Administration Order 5700.1 


\section{DISTRIBUTION}

Congressional Information Service, Bethesda, MD

Office of Environmental Policy and Assistance, EH-41

Office of Environmental Audit, EH-24

Office of NEPA Policy and Assistance, EH-42

Office of Science and Technological Information

DOE Scientific and Technical Information Center

Corporate Service Office, Western Area Power Administration, $\mathrm{A} 0000, \mathrm{~A} 0200, \mathrm{~A} 0300, \mathrm{~A} 0500, \mathrm{~A} 0600, \mathrm{~A} 1000, \mathrm{~A} 3000, \mathrm{~A} 8000$

Regional Manager, B0000, Upper Great Plains Customer Service Region Regional Manager, G0000, Desert Southwest Customer Service Region Regional Manager, J0000, Rocky Mountain Customer Service Region Regional Manager, N0000, Sierra Nevada Customer Service Region Manager, L0000, CRSP Customer Service Center (Salt Lake City) Environmental Manager, B0400, Upper Great Plains CSR

Environmental Manager, G0400, Desert Southwest CSR

Environmental Manager, J0400, Rocky Mountain CSR

Environmental Manager, N0400, Sierra Nevada CSR

Environmental Manager, L0400, Customer Service Center (Salt Lake City)

American Statistics Index, Congressional Information Service, Bethesda, MD

Bonneville Power Administration 


\section{APPENDIX A}

Standard Mitigative Measures for

Construction, Operation, and Maintenance

of Transmission Lines 


\section{APPENDIX A. STANDARD MITIGATIVE PRACTICES}

\section{Mitigation}

Measure

1. The contractor shall limit the movement of its crews and equipment to the rightof-way (ROW), including access routes. The contractor shall limit movement on the ROW so as to minimize damage to grazing land, crops, or property, and shall avoid marring the land.

2. When weather and ground conditions permit, the contractor shall obliterate all contractor-caused deep ruts that are hazardous to farming operations and to movement of equipment. Such ruts shall be leveled, filled, and graded, or otherwise eliminated in an approved manner. In hay meadows, alfalfa fields, pastures, and cultivated productive lands, ruts, scars, and compacted soils shall have the soil loosened and leveled by scarifying, harrowing, discing, or other approved methods. Damage to ditches, tile drains, terraces, roads, and other features of the land shall be corrected. Before final acceptance of the work in these agricultural areas, all ruts shall be obliterated, and all trails and areas that are hard-packed as a result of contractor operations shall be loosened, leveled, and reseeded. The land and facilities shall be restored as nearly as practicable to their original conditions.

3. Water bars or small terraces shall be constructed across all ROW and access roads on hillsides to prevent water erosion and to facilitate natural revegetation.

4. The contractor shall comply with all Federal, State, and local environmental laws, orders, and regulations. Prior to construction, all supervisory construction personnel and heavy equipment operators will be instructed on the protection of cultural and ecological resources.

5. The contractor shall exercise care to preserve the natural landscape and shall conduct its construction operations so as to prevent any unnecessary destruction, scarring, or defacing of the natural surroundings in the vicinity of the work. 
Except where clearing is required for permanent works, approved construction roads, or excavation operations, all trees, native shrubbery, and vegetation shall be preserved and shall be protected from damage by the contractor's construction operations and equipment. The edges of clearings and cuts through tree, shrubbery, or other vegetation shall be irregularly shaped to soften the undesirable visual impact of straight lines. Where such clearing occurs in the Lake Mead National Recreation Area, the contractor shall consult with the on-site Park Representative.

6. On completion of the work, all work areas except access roads shall be scarified or left in a condition which will facilitate natural revegetation, provide for proper drainage, and prevent erosion. All destruction, scarring, damage, or defacing of the landscape resulting from the contractor's operations shall be repaired by the contractor.

7. Construction staging areas shall be located and arranged in a manner to preserve trees and vegetation to the maximum practicable extent. On abandonment, all storage and construction buildings, including concrete footings and slabs, and all construction materials and debris shall be removed from the site. The area shall be regraded as required so that all surfaces drain naturally, blend with the natural terrain, and are left in a condition that will facilitate natural revegetation, provide for proper drainage, and prevent erosion.

8. Borrow pits shall be excavated so that water will not collect and stand therein. Before being abandoned, the sides of borrow pits shall be brought to stable slopes, with slope intersections shaped to carry the natural contour of adjacent undisturbed terrain into the pit or borrow area giving a natural appearance. Waste piles shall be shaped to provide a natural appearance.

9. Construction activities shall be performed by methods that will prevent entrance, or accidental spillage, of solid matter contaminants, debris, any other objectionable pollutants and wastes into streams, flowing or dry watercourses, lakes, and underground water sources. Such pollutants and waste include, but are 
not restricted to refuse, garbage, cement, concrete, sanitary waste, industrial waste, radioactive substances, oil and other petroleum products, aggregate processing tailing, mineral salts, and thermal pollution.

10. Dewatering work for structure foundations or earthwork operations adjacent to, or encroaching on, streams or watercourses, shall be conducted in a manner to prevent muddy water and eroded materials from entering the streams or watercourses by construction of intercepting ditches, bypass channels, barriers, settling ponds, or by other approved means.

11. Excavated material or other construction materials shall not be stockpiled or deposited near or on stream banks, lake shorelines, or other watercourse perimeters where they can be wasted away by high water or storm runoff or can in any way encroach upon the actual watercourse itself.

12. Waste waters from concrete batching, or other construction operations shall not enter streams, watercourses, or other surface waters without the use of such turbidity control methods as settling ponds, gravel-filter entrapment dikes, approved flocculating processes that are not harmful to fish, recirculation systems for washing of aggregates, or other approved methods. Any such waste waters discharged into surface waters shall be essentially free of settleable material. For the purpose of these specifications, settleable material as defined as that material which will settle from the water by gravity during a 1-hour quiescent detention period.

13. The contractor shall utilize such practicable methods and devices as are reasonably available to control, present, and otherwise minimize atmospheric emissions or discharges of air contaminants.

14. The emission of dust into the atmosphere will not be permitted during the manufacture, handling, and storage of concrete aggregate, and the contractor shall use such methods and equipment as necessary for the collection and disposal, or prevention, of dust during these operations. The contractor's methods of storing 
and handling cement and pozzolans shall also include means of eliminating atmospheric discharges of dust.

15. Equipment and vehicles that show excessive emissions of exhaust gases due to poor engine adjustments, or other inefficient operating conditions, shall not be operated until repairs or adjustments are made.

16. The contractor shall prevent any nuisance to persons or damage to crops, cultivated fields, and dwellings from dust originating from his operations. Oil and . other petroleum derivatives shall not be used for dust control. Speed limits shall be enforced, based on road conditions, to reduce dust problems.

17. To avoid nuisance conditions due to construction noise, all internal combustion engines used in connection with construction activity shall be fitted with an approved muffler and spark arrester.

18. Burning or burying waste materials on the ROW or at the construction site will be permitted if allowed by local regulations. The contractor shall remove all other waste materials from the construction area. All materials resulting from the contractor's clearing operations shall be removed from the ROW.

19. The contractor shall make all necessary provisions in conformance with safety requirements for maintaining the flow of public traffic and shall conduct its construction operations to offer the least possible obstruction and inconvenience to public traffic.

20. Western will apply necessary mitigation to eliminate problems of induced currents and voltages onto conductive objects sharing a ROW, to the mutual satisfaction to the parties involved.

21. Structures will be carefully located to avoid sensitive vegetative conditions, including wetlands, where practical. 
22. ROW will be located to avoid sensitive vegetation conditions including wetlands where practical, or, if they are linear to cross them at the least sensitive feasible point.

23. Removal of vegetation will be minimized to avoid creating a swath along the ROW.

24. Topsoil will be removed, stockpiled, and respread at all heavily disturbed areas not needed for maintenance access.

25. All disturbed areas not needed for maintenance access will be reseeded using mixes approved by the landowner or land management agency.

26. Erosion control measures will be implemented on disturbed areas, including areas that must be used for maintenance operations (access ways and areas around structures).

27. The minimum area will be used for access ways ( 12 feet to 15 feet wide, except where roadless construction is used).

28. Structures will be located and designed to conform with the terrain. Leveling and benching of the structure sites will be the minimum necessary to allow structure assembly and erection.

29. ROW will be located to utilize the least steep terrain and, therefore, to disturb the smallest area feasible.

30. Careful structure location will ensure spanning of narrow flood prone areas.

31. Structures will not be sited on any potentially active faults.

32. Structure sites and other disturbed areas will be located at least 300 feet, where practical, from rivers, streams (including ephemeral streams), ponds, lakes, and reservoirs. 
33. New access ways will be located at least 300 feet, where practical, from rivers, ponds, lakes, and reservoirs.

34. At crossings of perennial streams by new access ways, culverts of adequate size to accommodate the estimated peak flow of the stream will be installed.

Construction areas will minimize disturbance of the stream banks and beds during construction. The mitigation measures listed for soil/vegetation resources will be performed on areas disturbed during culvert construction.

35. If the banks of ephemeral stream crossings are sufficiently high and steep that breaking them down for a crossing would cause excessive disturbance, culverts will be installed using the same measures as for culverts on perennial streams.

36. Blasting will not be allowed.

37. Power line structures will be located, where practical, to span small occurrences of sensitive land uses, such as cultivated areas. Where practicable, construction access ways will be located to avoid sensitive conditions.

38. ROW will be purchased at fair market value and payment will be made of full value for crop damages or other property damage during construction or maintenance.

39. The Power line will be designed to minimize noise and other effects from energized conductors.

40. The precise location of all structure sites, ROW, and other disturbed areas will be determined in cooperation with landowners or land management agencies.

41. Crossing of operating railroads by construction vehicles or equipment in a manner that would cause delays to railroad operations will be avoided. Construction will be coordinated with railroad operators. Conductors and overhead wire string operations would use guard structures to eliminate delays. 
42. Before construction, Western will perform a Class III (100 percent of surface) cultural survey on all areas to be disturbed, including structure sites and new access ways. These surveys will be coordinated with the appropriate land owner or land management agency. A product of the survey will be a Cultural Resources Report recording findings and suggesting mitigation measures. These findings will be reviewed with the State Historic Preservation Offices and other appropriate agencies, and specific mitigation measures necessary for each site or resource will be determined. Mitigation may include careful relocation of access ways, structure sites, and other disturbed areas to avoid cultural sites that should not be disturbed, or data recovery.

43. The contractor will be informed of the need to cease work in the location if cultural resource items are discovered.

44. Construction activities will be monitored or sites flagged to prevent inadvertent destruction of any cultural resource for which the agreed mitigation was avoidance.

45. Construction crews will be monitored to the extent possible to prevent vandalism or unauthorized removal or disturbance of cultural artifacts or materials from sites where the agreed mitigation was avoidance.

46. Should any cultural resources that were not discovered during the Class III Survey be encountered during construction, ground disturbance activities at that location will be suspended until the provisions of the National Historic Preservation Act and enabling legislation have been carried out.

47. Construction activities will be monitored or significant locations flagged to prevent inadvertent destruction of any paleontological resource for which the agreed mitigation was avoidance.

48. Clearing for the access road will be limited to only those trees necessary to permit the passage of equipment. 
49. The access road will follow the lay of the land rather than a straight line along the ROW where steep features would result in a higher disturbance. 
APPENDIX B

REPORT ON THE

MITIGATION ACTION PLAN

FOR THE

SACRAMENTO OPERATIONS CENTER 


\section{APPENDIX B. REPORT ON THE MITIGATION ACTION PLAN FOR THE SACRAMENTO OPERATIONS CENTER}

The Sierra Nevada Regional Office constructed an operations center (SOC) in Folsom, California, to eliminate overcrowding at its existing Sacramento facilities, and improve operation efficiency. Habitat for one Federally listed threatened species, the Valley Elderberry Longhorn Beetle (Desmocerus californicus dimorphus), was identified at the project site. Of the two shrubs identified, one would be affected by the proposed action. Mitigation and compensation measures were subsequently established.

The following is a compendium of the annual reports on the review of the mitigation measures implemented.

Mitigation and compensation measures implemented at the SOC:

- Location of a mitigation area was identified in the northernmost portion of the property.

- The relocation of the one elderberry shrub occurred on November 13, 1992, and followed the guidelines specified by the U.S. Fish and Wildlife Service. [To increase the likelihood of plant survival, transplanting and replacement planting was conducted during the winter months (November through March) when the shrub was dormant.]

- Protective construction fencing was installed around the second elderberry shrub on the site.

- Habitat compensation planting occurred on March 11, 1993. The replacement planting ratio used to mitigate the transplanted elderberry shrub was 5:1. Transplanting efforts followed the recommended guidelines specified by the U.S. Fish and Wildlife Service (USFWS) and included 20 elderberry seedlings, eight oak saplings, a bubbler irrigation system, and protective chain-link fencing.

- Meeting with USFWS to review possible impacts to 10-acre site on October 9, 1993. 
- Transmitted letter to USFWS to apprise them of results of the mitigation and monitoring effort on October 26, 1993.

- A couple of bushes were replaced prior to end of construction and the irrigation system repaired after tampering by a vagrant was discovered.

- Task order prepared for contractor to monitor mitigation area for first 3years until buildings are occupied and Western personnel on hand.

Surveys conducted in 1994 indicated that only two of the 20 elderberry plants had not survived. All oak saplings were surviving.

Surveys conducted in 1995 indicated that all of the remaining 18 elderberry plants had survived. All oak saplings were surviving.

Surveys conducted in 1996 indicated that four of the oak saplings have died and need to be replaced, and three of the elderberry stems have died and need to be replaced. The losses were attributed to the irrigation system. Repairs to system preceded replacement of any plant material. Overall the mitigation appears to be meeting the goals of the plan.

The irrigation system was repaired and weeding was done to limit stress on the plants. Oak and elderberry seedlings were replanted in November 1996.

Surveys in 1997 indicate that the goals of the mitigation plan are being met at this time. Based on previous reports, there is currently a 90 percent success rate of elderberry bushes and a 100 percent success rate of live oaks. The mitigation plantings appear stable and continued monitoring is recommended for the replacement live oak plantings until they become successfully established. No indications of beetle usage have been identified.

Surveys conducted in 1998 showed new growth on all planted and transplanted specimens. Weeds have invaded the mitigation areas, but have not adversely affected the shrubs and trees. The Facility Management Team accompanied the survey. Each of the elderberry clumps (EB\#1 5) had five elderberry plants in them, with all showing new 
shoots. Variation in the growth, probably based on age of the cuttings, is obvious. It is hoped that the larger cuttings will nurture the replantings until the oaks mature enough to do the job. There are numerous live oak seedlings in the mitigation area.

Because of the spring rains of 1998, the water emitters have not functioned as yet. The Facility Management Team will inspect them as watering becomes necessary. The Team will also look into replanting the stunted elderberries and possibly fertilize them if it seems needed. Previous survey reports expressed concern over the appearance of sedges and other wetland species occurring with the elderberry clumps. It does not appear that excess water has adversely affected the elderberries, but that will be watched. 
APPENDIX C

REPORT ON THE

MITIGATION ACTION PLAN

FOR THE

SUTTER POWER PLANT 


\section{Mitigation Action Plan \\ for the \\ Sutter Power Project Interconnection}

\section{INTRODUCTION}

Calpine Corporation (Calpine) proposes to construct the Sutter Power Project (SPP) in Sutter County, California, on a portion of a 77-acre parcel of land owned by Calpine (see Figure 1, page 5). The SPP will consist of a nominal 500-megawatt (MW) net electrical output natural gas-fired, combined-cycle generating facility. The power plant and Western's Keswick-Elverta and Olinda-Elverta double-circuit 230-kilovolt $(\mathrm{kV})$ transmission lines will be interconnected by a generation tie line consisting of approximately 4 miles of $230-\mathrm{kV}$ transmission line and a $230-$ $\mathrm{kV}$ switching station at some point south and west of the plant. This generation tie line will be constructed as a double-circuit transmission line, but initially operated as a single circuit. A new 12-mile natural gas pipeline would be constructed to provide fuel for the project. The SPP will be a "merchant plant," selling power on a short-term and midterm basis to customers, and on the spot market. Calpine will assume all economic costs. Power produced by this plant will be sold at the market price and made available to all market participants.

Calpine submitted a request to Western for a direct interconnection of Calpine's SPP with Western's electric transmission system. In response to this request, Western completed an Interconnection Feasibility Study that determined it would need certain direct interconnection facilities, modification of associated facilities and operational adjustments to its transmission system to accommodate the SPP generation. Western is moving forward on an Interconnection Agreement with Calpine for the SPP, including agreements for making the appropriate modifications to Western's transmission system.

Western is the lead Federal agency pursuant to the National Environmental Policy Act (NEPA) for the SPP. The California Energy Commission (Commission), a regulatory agency of the State of California, has the statutory authority to license thermal power plants of $50 \mathrm{MW}$ or more and is the state lead agency for the SPP. The Commission prepares environmental documentation equivalent to the California Environmental Quality Act. Western and the Commission determined that joining the two processes would provide many benefits to the public. The 
Commission and Western released a joint Draft Environmental Impact Statement (EIS)/Final Staff Assessment (FSA) in October 1998. Following the release of Western's Draft EIS, Western determined that the next document in the Commission process, the Presiding Member's Proposed Decision (PMPD), would be an inappropriate form for Western to present responses to comments on the Draft EIS. Western was concerned that combining the PMPD and the Final $E I S$ could appear to predecision the outcome of the review process. Therefore, Western prepared its own Final EIS, with input from the Commission. Western released the Final EIS in April 1999. Western has prepared a Record of Decision (ROD) for the SPP and this Mitigation Action Plan (MAP) details the specific mitigation required in that Record of Decision. This MAP was developed in accordance with NEPA (42 U.S.C. 4321, et seq.), the Council on Environmental Quality NEPA implementing regulations (40 CFR parts 1500-1508), and Department of Energy regulations implementing NEPA procedures (10 CFR part 1021). This MAP specifically addresses the requirements of 10 CFR $\S 1021.331$ on Mitigation Action Plans.

\section{MITIGATION}

The EIS process identified impacts that would occur as a result of the proposed action and a series of mitigative measures to minimize those impacts. A total of 165 Conditions of Certification, essentially mitigation measures and controls, were identified in the Commission's Decision on the SPP. Western has summarized all of these conditions in the Final EIS, Appendix O. However, not all of these Conditions relate to Western's action of agreeing to an interconnection. This $M A P$ details mitigation for those actions needed to allow an interconnection with Western's transmission system. The site specific mitigation measures listed in Appendix A are fully described in the Final EIS (Appendix 0) and in the Commission's Decision. These documents should be reviewed in conjunction with this plan to better understand the mitigation measures listed in the appendix. Additionally, some mitigative measures were included to provide Western with information to monitor and interact with the project, as necessary, such as providing the names of project managers, etc. 
Copies of the Draft and Final EIS may be obtained by contacting:

Ms. Loreen McMahon, Environmental Project Manager

Sierra Nevada Customer Service Region

Western Area Power Administration

114 Parkshore Drive, Folsom, CA 95630-4710

Telephone: (916) 353-4460

E-mail: $\underline{\text { mcmahon@wapa.gov }}$

Websites containing these documents and information regarding this project include:

Western Area Power Administration:

U.S. Department of Energy: http://www.wapa.gov

http://www.tis.eh.doe.gov/nepa/

\section{MONITORING AND REPORTING}

Western's Sierra Nevada Customer Service Region will monitor the mitigation described in this Plan (Appendix A). In accordance with DOE Order 5440.1E, Western will submit an annual report to DOE's Office of NEPA Policy and Assistance, EH-42, beginning with the first Annual Site Environmental Report prepared after the onset of construction activities, regarding the status of the mitigative measures and any changes associated with them. (The changes could come about as the result of a landowner request or changes in the status of an environmental resource.) The Commission's Compliance Project Manager (CPM) will monitor the 165 Conditions of Certification. Western will be consulted on these actions, where appropriate. Western's contact for mitigation monitoring will be the Environmental Project Manager, see above.

\section{CONSERVATION}

Section 7(a)(1) of the Endangered Species Act (ESA) directs Federal agencies to use their authorities to further the purposes of the ESA by carrying out conservation programs benefiting endangered and threatened species and the ecosystems upon which they depend. To that end, Western will incorporate conservation recommendations provided in the USFWS ${ }^{1}$ biological opinion, to the extent practicable. 
This $M A P$ has provisions for the USFWS conservation recommendation to include random ground searches for bird strikes during migration and wintering periods. ${ }^{2}$

\section{DOCUMENT PREPARERS}

Loreen McMahon, Environmental Project Manager

Nick Chevance, Environmental Specialist

Nancy Werdel, Environmental Manager

\section{DOCUMENTS REFERENCED}

California Energy Commission. 1999. Commission Decision: Application for Certification for the Sutter Power Plant Project, Docket No. 97-AFC-2. Sacramento, CA.

Calpine Corporation. 1998. Biological Resources Mitigation Implementation Plan for the Sutter Power Plant Project, Sutter County, California. Sacramento, CA.

Western Area Power Administration and California Energy Commission. 1998. Final Staff Assessment/Draft Environmental Impact Statement Filed Jointly for the Sutter Power Project (Application for Certification 97-AFC-2), Sutter County, California. Sacramento, CA.

Western Area Power Administration. 1999. Sutter Power Project Final Environmental Impact Statement (DOE-EIS 0294). Sacramento, CA

\section{LIST OF ACRONYMS}

$\mathrm{BO}$ biological opinion

BRMIMP Biological Resource Mitigation Implementation and Monitoring Plan

Calpine Calpine Corporation

$\mathrm{CBO}$ chief building official CCR California Code of Regulations 


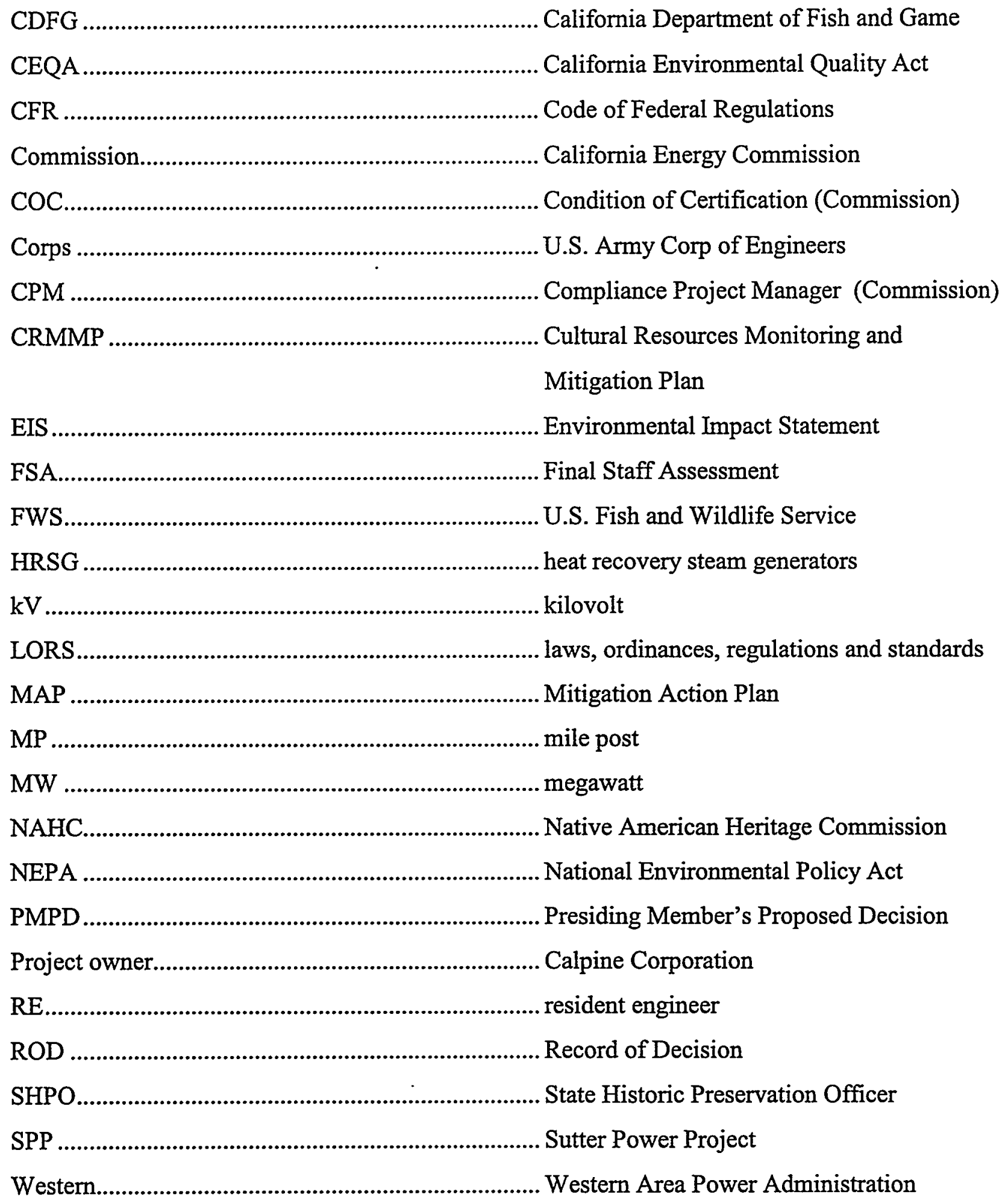


Area Map

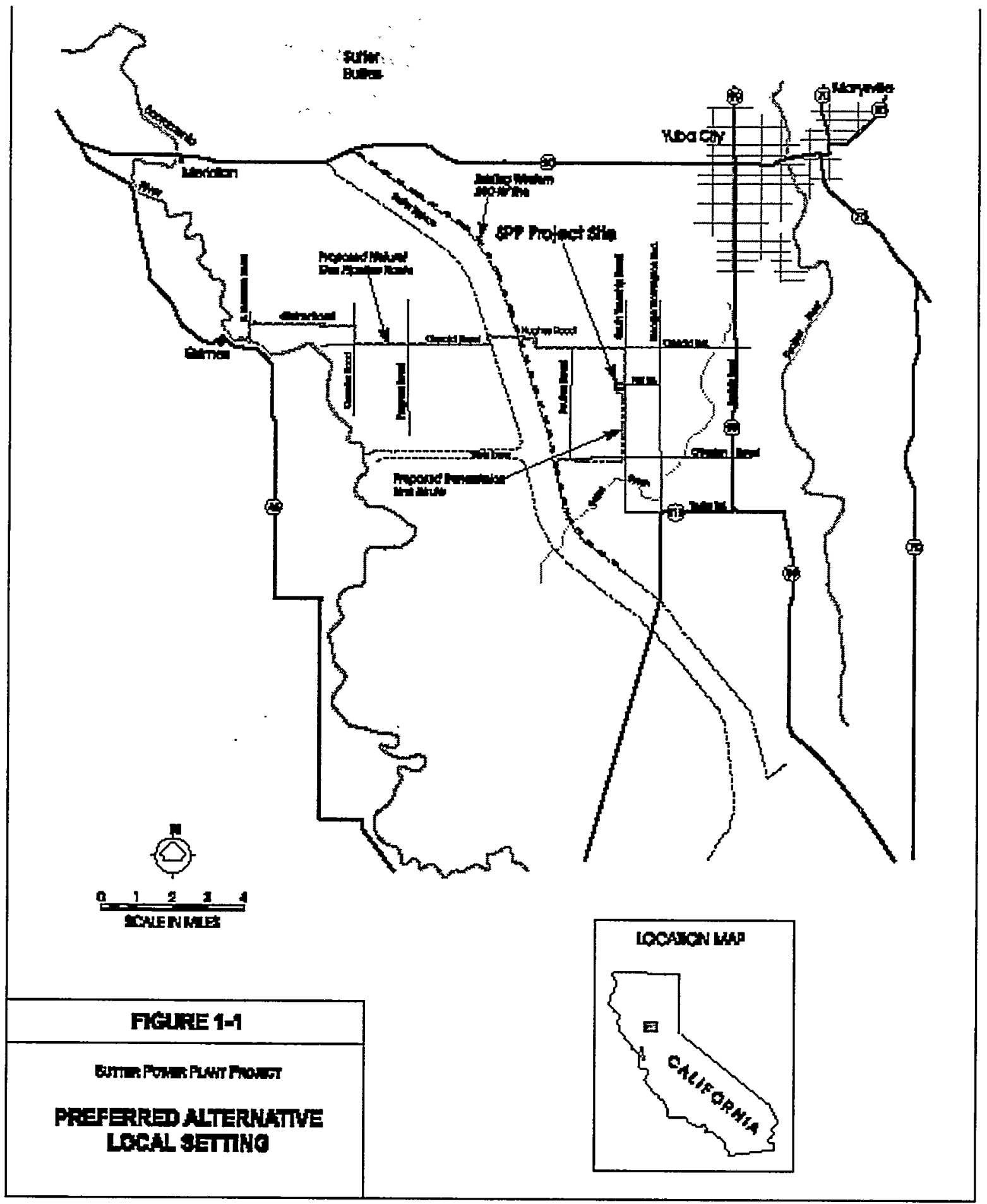




\title{
Appendix A:
}

\author{
Mitigation of Interconnection Impacts \\ by Resource ${ }^{3}$
}

\section{AIR QUALITY}

\section{A. Environmental Coordinator}

Description of Commission Condition of Certification (COC): Prior to the start of construction (defined as any construction-related vegetation clearance, ground disturbance and preparation and site excavation and soil remediation activities), the project owner shall provide the CPM with the following information: the name, telephone number, resume and indication of the environmental coordinator's on-site availability.

Protocol: The resume shall include appropriate education and/or experience in environmental management or coordination such as monitoring hazardous waste site remediation, experience as an inspector with an air pollution control district, or experience as an environmental health and safety project manager.

The CPM will review the qualifications of, and must approve in writing, the project owner's designated environmental coordinator prior to the start of construction. ${ }^{4}$

\begin{tabular}{|c|c|}
\hline $\begin{array}{c}\text { COMMISSION } \\
\text { VERIFICATION PROCESS } \\
\end{array}$ & $\begin{array}{l}\text { WESTERN } \\
\text { MONITORING }\end{array}$ \\
\hline $\begin{array}{l}\text { At least } 30 \text { days prior to the start of construction, } \\
\text { the project owner shall submit to the CPM for } \\
\text { review and written approval the information } \\
\text { required above. }\end{array}$ & $\begin{array}{l}\text { Calpine will provide Western with a copy of the } \\
\text { CPM approval and the resume of the selected } \\
\text { environmental coordinator. }\end{array}$ \\
\hline
\end{tabular}

\section{LAND USE}

\section{A. Sutter County Board of Supervisors Coordination}

Description of Commission Condition of Certification: Where indicated by safety concerns, the transmission line shall have a minimum clearance of 42 feet from the ground to

3 This document does not attempt to quote verbatim the Commission's Conditions of Certification. The COC information is provided as background data for Western's monitoring. A COC citation is provided for reference to the complete text, located in the SPP Final EIS.

4 SPP Final EIS, Appendix O, page 1, AQ-3.

5 Ibid, page 1, AQ-3. 
the conductor at maximum sag and the transmission line shall be designed to satisfy the safety concerns of Sutter Extension Water District and Sutter County (on behalf of aerial applicator safety, and public safety), including any applicable provisions of Article 86, state of California High Voltage Electrical Safety Order, section $2946^{6}$

\begin{tabular}{|l|l|}
\hline \multicolumn{1}{|c|}{ COMMISSION } & \multicolumn{1}{|c|}{\begin{tabular}{c}
\multicolumn{1}{|c|}{ WESTERN } \\
MONITORING
\end{tabular}} \\
\hline $\begin{array}{l}\text { At least 30 days prior to the start of construction the } \\
\text { project owner shall submit to the CPM a copy of a } \\
\text { letter from the Sutter County Board of Supervisors } \\
\text { stating that the Board of Supervisors has conferred } \\
\text { with Calpine and the Sutter Extension Water } \\
\text { District to agree on measures necessary to ensure } \\
\text { compliance of the transmission line with the } \\
\text { applicable provisions of Article 86, state of } \\
\text { California High Voltage electrical Safety Order, } \\
\text { section 2946. }\end{array}$ & $\begin{array}{l}\text { Calpine will provide Western with the letter from } \\
\text { the Sutter County Board of Supervisors at the same } \\
\text { time it is submitted to the CPM. }\end{array}$ \\
\hline
\end{tabular}

\section{VISUAL RESOURCES}

\section{B. Transmission Line Plan}

Description of Commission Condition of Certification: To minimize potential visual impacts, the project owner shall place all electrical transmission poles so as to not be directly in front of any residence and, to the extent possible, so as to not be directly in the view of the Sutter Buttes from any residence.

Protocol: At least 60 days prior to construction of the transmission line, the project owner shall submit a plan to the CPM showing:

- All proposed pole locations;

- All residences within one-quarter mile of the proposed transmission line route that have a view of the transmission line;

- The line of sight from each of the residences toward the Sutter Buttes.

6 SPP Final EIS, Appendix O, page 8, Land Use-5.

7 Ibid. 
Project owner shall prepare and submit a revised plan if the CPM provides notification to the project owner that it is needed for approval.

Transmission pole placement shall not begin before the plan is approved. The project owner shall notify the CPM when the poles have been installed and are ready for inspection. ${ }^{8}$

\begin{tabular}{|l|l|}
\hline \multicolumn{1}{|c|}{ COMMISSION } & \multicolumn{1}{c|}{\begin{tabular}{c}
\multicolumn{1}{c|}{$\begin{array}{c}\text { WESTERN } \\
\text { MONIFICATION PROCESS }\end{array}$} \\
\hline $\begin{array}{l}\text { At least } 60 \text { days prior to beginning transmission } \\
\text { line construction, the project owner shall provide } \\
\text { the electrical transmission pole plan to the CPM for } \\
\text { review and approval. }\end{array}$
\end{tabular}} \\
$\begin{array}{l}\text { If the CPM notifies the project owner that revisions } \\
\text { of the plan are needed before the CPM will approve } \\
\text { the plan, the project owner shall submit to the CPM } \\
\text { a revised plan within } 30 \text { days of receiving that } \\
\text { notification }\end{array}$ & $\begin{array}{l}\text { plan (and any requested revisions) to Western at the } \\
\text { same time they submit the required material to the } \\
\text { CPM. }\end{array}$ \\
$\begin{array}{l}\text { The project owner shall notify the CPM within } \\
\text { seven days after completing transmission line } \\
\text { construction that the line is ready for inspection. }\end{array}$ & \\
\hline
\end{tabular}

\section{BIOLOGICAL RESOURCES}

\section{Designation of Biologist}

Description of Commission Condition of Certification: Construction-site and/or ancillary facilities preparation (described as any ground-disturbing activities other than allowed geotechnical work) shall not begin until the CPM-approved, designated biologist is available on site.

Protocol: The designated biologist must meet the following minimum qualifications:

1) A bachelor's degree in biological sciences, zoology, botany, ecology or a closely related field;

2) Three years of experience in field biology or current certification of a nationally recognized biological society, such as the Ecological Society of America of the Wildlife Society; 
3) One year of field experience with resources found in or near the project area;

4) Ability to demonstrate to the satisfaction of the CPM the appropriate education and experience for biological resource tasks to be addressed during project construction and operation.

If within 30 days of receiving the proposed designation, the CPM determines the proposed designated biologist is unacceptable, the project owner shall submit another individual's name and qualifications for consideration.

If the approved designated biologist needs to be replaced, the project owner shall obtain approval of a new designated biologist by submitting to the CPM the name, qualifications, address and telephone number of the proposed replacement.

No disturbance will be allowed in any designated sensitive area(s) until the CPM approves a new designated biologist and designated biologist is on-site. ${ }^{10}$

\begin{tabular}{|l|l|}
\hline \multicolumn{1}{|c|}{ COMMISSION } & \multicolumn{1}{c|}{$\begin{array}{c}\text { WESTERN } \\
\text { MONITORING }\end{array}$} \\
\hline $\begin{array}{l}\text { At least } 30 \text { days prior to the start of rough grading, } \\
\text { the project owner shall submit to the CPM for } \\
\text { approval, the name, qualifications, address and } \\
\text { telephone number of the individual selected by the } \\
\text { project owner as the designated biologist. If a } \\
\text { designated biologist is replaced the information on } \\
\text { the proposed replacement as specified in the } \\
\begin{array}{l}\text { Condition must be submitted in writing at least 10 } \\
\text { working days prior to the termination or release of } \\
\text { the preceding designated biologist. }\end{array}\end{array}$ & $\begin{array}{l}\text { Calpine will provide Western with a copy of the } \\
\text { qualifications of the CPM-approved biologist and a } \\
\text { copy of the Commission-approval and designation } \\
\text { of the designated biologist prior to the } \\
\text { commencement of construction activities. }\end{array}$ \\
\hline
\end{tabular}

\section{Biological Non Compliance Protocol}

Description of Commission Condition of Certification: The project owner's supervising construction and operating engineer shall act on the advice of the designated biologist to ensure conformance with the biological resource COC.

8 SPP Final EIS, Appendix O, page 11, VIS-7.

9 Ibid.

10 SPP Final EIS, Appendix O, page 11, BIO-1.

11 Ibid. 
Protocol: The project owner's supervising construction and operating engineer shall halt, if needed, all construction activities in areas identified by the designated biologist as sensitive to ensure potential significant biological resource impacts are avoided.

The designated biologist shall:

1) Tell the project owner and the supervising construction and operating engineer when to resume construction;

2) Advise the CPM if any corrective actions are needed or have been instituted. ${ }^{12}$

\begin{tabular}{|l|l|}
\hline \multicolumn{1}{|c|}{ COMMISSION } & \multicolumn{1}{|c|}{$\begin{array}{c}\text { WESTERN } \\
\text { VERIFICATION PROCESS }\end{array}$} \\
$\begin{array}{l}\text { Within two working days of a designated } \\
\text { biologist's notification of non compliance with a } \\
\text { Biological Resources Condition or a halt of } \\
\text { construction, the project owner shall notify the } \\
\text { CPM by telephone of the circumstances and actions } \\
\text { being taken to resolve the problem or the non } \\
\text { compliance with a COC. }\end{array}$ & $\begin{array}{l}\text { Calpine will ensure that its supervising construction } \\
\text { and operating engineer act on the advice of the } \\
\text { designated biologist and understand the biologist } \\
\text { has the authority to halt construction, if the } \\
\text { biologist deems it necessary. Within two working } \\
\text { days of a designated biologist's notification of non- } \\
\text { compliance with a Biological Resources Condition } \\
\text { or a halt of construction. Calpine shall notify } \\
\text { Western by telephone of the circumstances and } \\
\text { actions being taken to resolve the problem or the } \\
\text { non-compliance. }\end{array}$ \\
$\begin{array}{l}\text { For any necessary corrective action taken by the } \\
\text { project owner, a determination of success or failure } \\
\text { will be made by the CPM within five working days } \\
\text { after receipt of notice that corrective action is } \\
\text { completed, or the project owner will be notified by } \\
\text { the CPM that coordination with other agencies will } \\
\text { require additional time before a determination can } \\
\text { be made. }\end{array}$ & $\begin{array}{l}\text { 13 } \\
\text { The designated biologist shall ensure the FWS } \\
\text { Sacramento Office Division Chief for Endangered } \\
\text { Species (3310 El Camino Avenue, Suite 130, } \\
\text { Sacramento, CA, 95821-6340, 916/979-2725) is } \\
\text { appropriately notified and consulted regarding } \\
\text { endangered species as noted in the biological } \\
\text { opinion. }{ }^{14} \text { This coordination includes all } \\
\text { monitoring, notifying and reporting requirements. } \\
\text { The designated biologist will comply with the FWS } \\
\text { reporting documentation and provide copies of all } \\
\text { communications with the FWS to Western. }\end{array}$ \\
\hline
\end{tabular}

E. Worker Environmental Awareness Program

Description of Commission Condition of Certification: The project owner shall develop and implement a Worker Environmental Awareness Program, in which each of its own employees, as well as employees of contractors and subcontractors who work on the project

12 SPP Final EIS, Appendix O, page 12, BIO-3.

13 Ibid.

14 Ibid., Appendix T. 
site or related facilities (including any access roads, storage areas, transmission lines, water and gas lines) during construction and operation, are informed about biological resource sensitivities associated with the project.

Protocol: The Worker Environmental Awareness Program:

1) Shall be developed by the designated biologist and consist of an on-site or classroom presentation in which supporting written material is made available to all participants;

2) Must discuss the locations and types of sensitive biological resources on the project site and adjacent areas;

3) Must present the reasons for protecting the resources;

4) Must present the meaning of various temporary and permanent habitat protection measures;

5) Must identify who to contact if there are further comments and questions about the material discussed in the program.

The program can be administered by a competent individual(s) acceptable to the designated biologist.

Each participant in the on-site Worker Environmental Awareness Program shall sign a statement declaring that the individual understands and shall abide by the guidelines set forth in the program material. The person administering the program shall also sign each statement.

The signed statements for the construction phase shall be kept on file by the project owner and made available for examination by the CPM for a period of at least six months after the start of commercial operation. Signed statements for the project owner for the duration of 
their employment and for six months shall keep active operational personnel on file after their termination. ${ }^{15}$

\begin{tabular}{|c|c|}
\hline $\begin{array}{l}\text { COMMISSION } \\
\text { VERIFICATION PROCESS }\end{array}$ & $\begin{array}{c}\text { WESTERN } \\
\text { MONITORING PROCESS }\end{array}$ \\
\hline $\begin{array}{l}\text { At least } 30 \text { days prior to the start of rough grading, } \\
\text { the project owner shall provide copies of the } \\
\text { Worker Environmental Awareness Program and all } \\
\text { supporting written materials prepared by the } \\
\text { designated biologist and the name and } \\
\text { qualifications of the person(s) administering the } \\
\text { program to the CPM for approval. The project } \\
\text { owner shall state in the monthly compliance report } \\
\text { the number of persons who have completed the } \\
\text { training in the prior month and a running total of } \\
\text { all persons who have completed the training to } \\
\text { date. }\end{array}$ & $\begin{array}{l}\text { Calpine will consult with the FWS in the } \\
\text { preparation of the Worker Environmental } \\
\text { Awareness Program and provide documentation of } \\
\text { this consultation to Western. At least } 30 \text { days prior } \\
\text { to the start of construction of the transmission line } \\
\text { and/or substation, Calpine shall provide copies of } \\
\text { the Worker Environmental Awareness Program to } \\
\text { Western. }\end{array}$ \\
\hline
\end{tabular}

\section{F. Giant Garter Snake Mitigation}

Description of Commission Condition of Certification: The project owner shall ensure the following measures are implemented to avoid or mitigate project impacts to giant garter snakes:

1) Avoid trenching or auguring activities within 200 feet of giant garter snake habitat from October 2 through April 30, where feasible.

2) Have the designated biologist on-site during construction activities that occur between October 1 and May 1. The FWS will be contacted if a giant garter snake is found trapped and they will come out to remove it.

3) Within 24 hours prior to the start of construction activities, the site shall be inspected for snakes by the designated biologist. Observed snakes should be reported and cleared to an area that will not be affected by construction within the next 24 hours. If a snake is encountered during construction activities, the designated biologist shall be contacted and take appropriate measures to ensure the snake is not harmed. 
4) Avoid obstructing the flow of water through the canals (dewatering). Any dewatered habitat must remain dry for at least 15 consecutive days after April 15 and 15 consecutive days prior to excavating or filling dewatered habitat.

5) Prevent construction activities run off from entering giant garter snake habitat.

6) Restrict vegetation clearing to the minimal area necessary to facilitate construction activities. Mark and avoid giant garter snake habitat in or adjacent to the project that will not be directly affected by construction activities.

7) Provide replacement habitat at a location acceptable to USFWS and the California Department of Fish and Game (CDFG) to compensate for habitat lost.

8) Mow, rather than disk, to control vegetation on-site. Mower blades should be raised to at least 6 inches during the snake's active period of May 1 to October 1.

9) Conduct activities to clear vegetation in the irrigation canals as necessary to minimize disturbance to snake habitat and in accordance with methods approved by USFWS and CDFG.

10) Eliminate wastewater discharge (as described in Condition Soils\&Water-217). ${ }^{18}$

\begin{tabular}{|c|c|}
\hline $\begin{array}{l}\text { COMMISSION } \\
\text { VERIFICATION PROCESS }\end{array}$ & WESTERNMONITORING \\
\hline $\begin{array}{l}\text { At least } 45 \text { days prior to rough grading, the project } \\
\text { owner shall provide to the project CPM for review } \\
\text { and approval written documentation (BRMIMP, } \\
\text { BIO-1219) that these measures will be or have } \\
\text { been taken by the licensee. The documentation } \\
\text { will specify the procedures used or that will be } \\
\text { used to implement these measures. }\end{array}$ & $\begin{array}{l}\text { Western will provide oversight of construction } \\
\text { activities to ensure transmission line and/or } \\
\text { substation construction activities: } \\
\text { (a) avoid auguring activities within } 200 \text { feet of } \\
\text { giant garter snake habitat between October } 2 \\
\text { and April } 30 \text {, } \\
\text { (b) have the CPM-approved biologist on-site } \\
\text { between October } 1 \text { and May } 1 \text {, } \\
\text { (c) have all areas to be disturbed checked for } \\
\text { snakes by the biologist and within } 24 \text {-hours }\end{array}$ \\
\hline
\end{tabular}

17 Ibid., Appendix O, page 18.

18 SPP Final EIS, Appendix O, page 13, BIO-8.

19 BRMIMP is a CA Energy Commission term for Biological Resource Mitigation Implementation and Monitoring Plan.

20 SPP Final EIS, Appendix O, page 13, BIO-8. 


\begin{tabular}{|c|c|}
\hline $\begin{array}{l}\text { COMMISSION } \\
\text { VERIFICATION PROCESS } \\
\end{array}$ & WESTERN MONITORING \\
\hline & $\begin{array}{l}\text { prior to commencement of construction } \\
\text { activities, the site shall be inspected by the } \\
\text { biologist, who will prepare a field report for } \\
\text { Western and the FWS, } \\
\text { (d) minimize vegetation clearing within snake } \\
\text { habitat, } \\
\text { (e) environmentally sensitive habitat will be } \\
\text { flagged by the biologist, as he determines } \\
\text { necessary for avoidance, } \\
\text { (f) use mowing for fire control, rather than } \\
\text { disking, } \\
\text { (g) use herbicides with no residual or migratory } \\
\text { effects, } \\
\text { (h) revegetate habitat after construction, and } \\
\text { (i) Calpine shall provide Western with } \\
\text { documentation of habitat compensation. }\end{array}$ \\
\hline
\end{tabular}

\section{G. Swainson's Hawk Mitigation}

Description of Commission Condition of Certification: The project owner shall ensure the following measures are implemented to mitigate or avoid project impacts to Swainson's hawks:

1) The designated biologist shall conduct preconstruction surveys during March through June construction years to determine if an active nest site is within 0.5 miles of construction activities.

2) The owner shall design the project to avoid removal of nest trees and to avoid placement of the transmission line within 0.1 mile of nest trees.

3) The designated biologist shall monitor construction activities that occur within 0.5 miles of an active next site between March 1 and August 15 or until fledglings are no longer dependent on the nest tree. The monitoring plan shall be acceptable to $\mathrm{CDFG}^{21}$ 


\begin{tabular}{|l|l|}
\hline \multicolumn{1}{|c|}{ COMMISSION } & \multicolumn{1}{|c|}{$\begin{array}{l}\text { WESTERN } \\
\text { VERIFICATION PROCESS }\end{array}$} \\
\hline $\begin{array}{l}\text { At least 45 days prior to rough grading, the project } \\
\text { owner shall provide to the project CPM for review } \\
\text { and approval written documentation (BRMIMP, } \\
\begin{array}{l}\text { Bio-12) that the above measures will be } \\
\text { accomplished by the applicant and specify the } \\
\text { procedures used or that will be used to implement } \\
\text { these measures. }\end{array}\end{array}$ & $\begin{array}{l}\text { Calpine shall provide Western with documentation } \\
\text { that the above measures are accomplished. } \\
\text { Western will consult with the designated biologist } \\
\text { to ensure the project owner avoids placement of } \\
\text { transmission line poles within } 0.1 \text { miles of } \\
\text { Swainson's hawk nesting trees. }\end{array}$ \\
\hline
\end{tabular}

\section{H. Migratory Bird Mitigation}

Description of Commission Condition of Certification: The project owner shall ensure the following measures are implemented to mitigate or avoid project impacts to migratory birds:

1) Powerlines shall be constructed following recommendations in Suggested Practices for Raptor Protection on Power Lines; The State of the Art in 1996 (Avian Powerline Interaction Committee, 1996).

2) Powerlines located in sensitive areas (e.g., over Gilsizer Slough and through potential foraging or flyway areas) shall be fitted with bird flight diverters placed on the ground wire at 16.4-foot intervals. Sensitive areas shall be identified in the BRMIMP (COC Bio-12).

3) Between October through March, measures shall be taken in areas of high migratory bird use (such as Gilsizer Slough) to flush birds from the construction area prior to stringing wires.

4) Develop a monitoring plan to analyze whether the transmission line and $\mathrm{HRSG}^{23}$ stacks are causing significant impacts from avian collision and/or electrocutions. If it is determined that significant impacts are occurring, remedial mitigation measures shall be proposed and implemented. A report presenting the monitoring data and a discussion of the mitigation effectiveness shall be provided annually for 10 years following the completion of construction. If it can be shown that impacts to birds 
from the project are not occurring, the licensee has the option to request staff to decrease the frequency or cease monitoring. ${ }^{24}$

\begin{tabular}{|c|c|}
\hline $\begin{array}{c}\text { COMMISSION } \\
\text { VERIFICATION PROCESS } \\
\end{array}$ & $\begin{array}{l}\text { WESTERN } \\
\text { MONITORING }\end{array}$ \\
\hline $\begin{array}{l}\text { At least } 45 \text { days prior to rough grading, the project } \\
\text { owner shall provide to the project CPM for review } \\
\text { and approval written documentation (BRMIMP, } \\
\text { Bio-12) that these measures will be accomplished } \\
\text { by the licensee and specify the procedures used or } \\
\text { that will be used to implement these measures. The } \\
\text { avian collision/electrocution monitoring plan annual } \\
\text { report shall be provided to the project CPM no later } \\
\text { than December } 31 \text { for each year monitoring is } \\
\text { required. }\end{array}$ & $\begin{array}{l}\text { Western will provide oversight of construction } \\
\text { activities to assure the transmission line and } \\
\text { substation activities: } \\
\text { (a) Consider the Practices for Raptor Protection } \\
\text { on Power Lines; The State of the Art in 1996, } \\
\text { (b) Fit powerlines located in areas sensitive to } \\
\text { migratory birds with bird flight diverters placed } \\
\text { on the ground wire at } 16.4 \text {-foot intervals, } \\
\text { (c) Provide suitable spacing between conductor } \\
\text { wires to minimize risk of electrocution, } \\
\text { (d) Attempt to flush birds from construction areas } \\
\text { prior to stringing wires, } \\
\text { (e) Have an avian collision monitoring plan. As a } \\
\text { conservation measure, the plan shall include a } \\
\text { provision for random ground searches for bird } \\
\text { strikes during migration and wintering periods. }\end{array}$ \\
\hline
\end{tabular}

\section{Wetland Mitigation}

Description of Commission Condition of Certification: The project owner shall ensure the following measures are implemented to mitigate or avoid project impacts on wetlands:

1) Provide in-kind replacement habitat at a location acceptable to FWS for wetlands impacted by the project (BIO-13).

2) Establish an endowment account adequate to provide funds for the perpetual maintenance and management of the replacement habitat.

3) Mark and avoid all wetlands on site that will not be directly taken by the power plant footprint and all wetlands along Hughes Road in the Sutter National Wildlife Refuge.

24 SPP Final EIS, Appendix O, page 14, BIO-10. (A full summary of this COC was not included above.) 25 Although Western's Biological Assessment indicated that strobe lights would be used on the HRSG stacks to deter avian collision, it was subsequently determined through the NEPA process and public involvement that strobe lights would cause a visual impact. Therefore, they will not be utilized.

26 SPP Final EIS, Appendix O, page 14, BIO-10. 
4) Protect on-site wetlands not taken by the power plant footprint in perpetuity or provide replacement habitat at a location and ratio acceptable to FWS and establish an endowment account adequate to provide funds for the perpetual maintenance and management of the replacement habitat.

5) Use an air-cooled condenser to eliminate wet-cooling tower evaporation and incorporate drains designed to route contaminated runoff away from the remaining wetlands or develop and implement a monitoring program to ensure the wetlands remaining on-site are not degraded by project operations. The program shall include parameters acceptable to FWS that monitor hydrologic quality and productivity, and identify and defend reference or control wetlands for comparative analysis. If it is determined that the on-site wetlands are negatively impacted, propose remedial mitigation measures to be implemented. A report presenting the monitoring data and a discussion of the mitigation effectiveness shall be provided annually for the life of the project. If it can be shown that wetlands are not being negatively impacted, the licensee has the option to request Commission staff to decrease the frequency or cease monitoring.

6) Place a construction cloth over wetlands that could be impacted only or where feasible, otherwise the wetlands will only be marked and flagged for avoidance.

7) Place the pipeline under or in the shoulder of Hughes Road. ${ }^{27}$

\begin{tabular}{|c|c|}
\hline $\begin{array}{l}\text { COMMISSIÓN } \\
\text { VERITICATION PROCESS }\end{array}$ & $\begin{array}{l}\text { WESTERN } \\
\text { MONITORING }\end{array}$ \\
\hline $\begin{array}{l}\text { At least } 45 \text { days prior to rough grading, the project } \\
\text { owner shall provide to the project CPM for review } \\
\text { and approval written documentation (BRMIMP, } \\
\text { BIO-12) that the above measures will be } \\
\text { accomplished by the licensee and specify the } \\
\text { procedural terms for implementing these measures. } \\
\text { The wetland monitoring plan annual report shall be } \\
\text { provided to the project CPM no later than July } 1 \text { for } \\
\text { each year monitoring is completed. }\end{array}$ & $\begin{array}{l}\text { Calpine shall provide Western with written } \\
\text { documentation verifying that the above measures } \\
\text { have been accomplished. Calpine shall provide } \\
\text { Western with a copy of the Wetland Monitoring Plan } \\
\text { and subsequent annual report(s). }\end{array}$ \\
\hline
\end{tabular}

27 SPP Final EIS, Appendix O, page 14.

28 Ibid., page 14, BIO-11. 


\section{J. Final Biological Reporting}

Description of Commission Condition of Certification: The project owner shall submit to the CPM for review and approval a copy of the final Biological Resources Mitigation Implementation and Monitoring Plan.

Protocol: The Biological Resources Mitigation Implementation and Monitoring Plan shall identify:

- All sensitive biologic resources to be impacted, avoided or mitigated by project construction and operation;

- All conditions agreed to in the FWS biological opinion and California Department of Fish and Game (CDFG) Incidental Take Permit;

- All mitigation, monitoring and compliance conditions included in the Commission's Final Decision;

- All conditions agreed to the in the U.S. Army Corps of Engineers (Corps) Clean Water Act permits;

- All conditions specified in the CDFG Streambed Alteration permit, if required;

- Required mitigation measures for each sensitive biological resource;

- Required habitat compensation, including provisions for acquisition, enhancement and management, for any loss of sensitive biological resources;

- A detailed plan for protecting the existence and monitoring the integrity of the wetlands remaining on-site;

- A detailed description of measures to be taken to avoìd or mitigate temporary disturbances from construction activities;

- All locations, on a map of suitable scale, of laydown areas and areas requiring temporary protection and avoidance during construction; 
- Aerial photographs of all areas to be disturbed during project construction activities-one set prior to site disturbance and one set subsequent to completion of mitigation measures. Include planned timing of aerial photography and description of why times were chosen;

- Monitoring duration for each type of monitoring and a description of monitoring methodologies and frequency;

- Performance standards to be used to help decide if/when proposed mitigation is or is not successful;

- All remedial measures to be implemented if performance standards are not met; and

- A process for proposing plan modifications to the CPM and appropriate agencies, for review and approval. ${ }^{29}$

\begin{tabular}{|c|c|}
\hline $\begin{array}{l}\text { COMMISSION } \\
\text { VERIFICATION PROCESS }\end{array}$ & $\begin{array}{r}\text { WESTERN } \\
\text { MONITORING }\end{array}$ \\
\hline $\begin{array}{l}\text { At least } 45 \text { days prior to rough grading, the project } \\
\text { owner shall provide the CPM with the final version } \\
\text { of the Biological Resources Mitigation } \\
\text { Implementation and Monitoring Plan for this project. } \\
\text { The CPM will determine the plan's acceptability } \\
\text { within } 15 \text { days of receipt of the final plan. The } \\
\text { project owner shall notify the CPM five working days } \\
\text { before implementing any modifications to the } \\
\text { BRMIMP. Within } 30 \text { days after completion of } \\
\text { construction, the project owner shall provide the } \\
\text { CPM, for review and approval, a written report } \\
\text { identifying which items of the BRMIMP have been } \\
\text { completed, a summary of all modifications to } \\
\text { mitigation measures made during the project's } \\
\text { construction phase and which condition items are still } \\
\text { outstanding. }\end{array}$ & $\begin{array}{l}\text { Calpine will review the December, } 1998 \text { Draft Final } \\
B R M I M P \text { and determine if modifications are needed } \\
\text { to meet the requirements of the Federal biological } \\
\text { opinion. They shall submit written results of this } \\
\text { review to Western for review and approval. A final, } \\
\text { updated BRMIMP will be provided to Western. } \\
\text { Calpine will work with the Commission to ensure that } \\
\text { both the BRMIMP and the Mitigation Action Plan } \\
\text { are coordinated and implemented. }\end{array}$ \\
\hline
\end{tabular}




\section{CULTURAL RESOURCES}

\section{K. Designation of Cultural Resource Specialist}

Description of Commission Condition of Certification: Prior to the start of project construction (defined as any construction-related vegetation clearance, ground disturbance and preparation and site excavation activities), the project owner shall provide the CPM and Western with the name(s) and qualifications of its designated cultural resource specialist and mitigation team members.

The designated cultural resource specialist shall be responsible for implementing all the cultural resource COCs, using qualified personnel to assist him or her in project-related field surveys, monitoring, data collection and artifact recovery, mapping, mitigation, analysis of recovered cultural resources, and data or report preparation.

After CPM and Western approval of the Cultural Resource Monitoring and Mitigation Plan

(CRMMP) (Cul-3), ${ }^{31}$ the designated cultural resource specialist and team shall be available to implement the mitigation plan prior to, and throughout construction of the project.

Protocol: The project owner shall provide the CPM and Western with a resume or statement of qualifications for its designated cultural resources specialist and mitigation team members. The resume(s) shall include the following information:

1) The resume for the designated cultural resource specialist shall demonstrate that the specialist meets the following minimum qualifications: a graduate degree in archeology, anthropology, California history or cultural resource management; at least three years of cultural resource mitigation and field experience in California, including at least 1-year's experience leading cultural resource field surveys; leading site mapping and data recording; marshaling equipment necessary and leading archaeological resource recovery operations; the need for appropriate sampling and/or testing in the field and in the lab; directing the analyses of mapped and recovered materials and data; and the preparation of appropriate reports to be filed 
with the receiving curation repository, the appropriate regional information center(s), the State Historic Preservation Officer (SHPO), Western, and the CPM.

2) The resume for the designated cultural resource specialist shall include a list of specific projects the specialist has previously worked on; the role and responsibilities of the specialist for each project listed; and the names and phone numbers of contacts familiar with the specialist's work on these referenced projects.

3) If additional personnel will be assisting the designated cultural resource specialist in project-related field surveys, monitoring, data and artifact recover, mapping, mitigation, material analysis or report preparation, the project owner shall also provide names, addresses, and resumes for these team members.

4) If the CPM and Western determine the qualifications of the proposed cultural resource specialist are not in concert with the above requirements, the project owner shall submit another individual's name and qualifications for consideration.

5) If the previously approved designated cultural resource specialist is replaced prior to completion of project mitigation, the project owner shall obtain CPM and Western approval of the new designated cultural resource specialist by submitting to the CPM and Western the name and qualifications of the proposed replacement specialist at least ten days prior to the termination or release of the preceding designated cultural resource specialist. ${ }^{32}$

\begin{tabular}{|l|l|}
\hline \multicolumn{1}{|c|}{ COMMISSION } & \multicolumn{1}{|c|}{ MESTERN } \\
\hline $\begin{array}{l}\text { At least } 90 \text { days prior to the start of construction, } \\
\text { the project owners shall submit the name and } \\
\text { resume of its designated cultural resource specialist } \\
\text { to the CPM and Western for review and written } \\
\text { approval. }\end{array}$ & $\begin{array}{l}\text { Western shall review the qualifications of the } \\
\text { project owner's selection for the designated cultural } \\
\text { resource specialist and provide written approval or } \\
\text { disapproval }\end{array}$ \\
$\begin{array}{l}\text { Thirty days prior to construction, the project owner } \\
\text { shall confirm in writing to the CPM, who will } \\
\text { notify Western, that the previously approved } \\
\text { designated cultural resource specialist and the team }\end{array}$ & \\
\hline
\end{tabular}




\begin{tabular}{|l|l|}
\hline \multicolumn{1}{|c|}{ COMMISSION } & \multicolumn{1}{|c|}{ VERIFICATION PROCESS } \\
MONITORING \\
\hline $\begin{array}{l}\text { of assistants are prepared to implement the } \\
\text { monitoring and mitigation measures for cultural } \\
\text { resources, as described in the Cultural Resources } \\
\text { Monitoring and Mitigation Plan. }\end{array}$ \\
$\begin{array}{l}\text { At least } 10 \text { days prior to the termination or release } \\
\text { of a designated cultural resource specialist, the } \\
\text { project owner shall obtain CPM and Western } \\
\text { approval of the new designated cultural resource } \\
\text { specialist by submitting to the CPM and Western } \\
\text { the name and resume of the proposed replacement } \\
\text { specialist. }\end{array}$
\end{tabular}

\section{Project Maps and Drawings of Facilities}

Description of Commission Condition of Certification: Prior to the start of project construction, the project owner shall provide the designated cultural resource specialist and the CPM with maps and drawings for the SPP. The final center lines and right-of-way boundaries shall be provided on 7.5 minute quad maps, and the location of all the various areas where surface disturbance may be associated with project-related access roads, storage yards, laydown sites, pull sites, pump or pressure stations, Sutter Bypass switching station, on-site switchyard, electrical tower or pole footings, etc.34

\begin{tabular}{|l|c|}
\hline \multicolumn{1}{|c|}{ COMMISSION } & \multicolumn{1}{c|}{$\begin{array}{c}\text { WESTERN } \\
\text { VERIFICATION PROCESS }\end{array}$} \\
\hline $\begin{array}{l}\text { At least } 90 \text { days prior to the start of construction on } \\
\text { the project, the project owner shall provide the } \\
\text { designated cultural resource specialist, the CPM, } \\
\text { and Western with final maps at appropriate scale(s) } \\
\text { and drawings for all project facilities. }\end{array}$ & $\begin{array}{l}\text { Western will review the maps and drawings and } \\
\text { coordinate with the designated cultural resource } \\
\text { specialist and the CPM, as appropriate. }\end{array}$ \\
\hline
\end{tabular}

\section{Cultural Resources Monitoring and Mitigation Plan}

\section{Description of Commission Condition of Certification: Prior to the start of project} construction, the designated cultural resource specialist shall prepare a draft Cultural Resources Monitoring and Mitigation Plan to identify general and specific measures to minimize potential impacts to significant cultural resources. The CPM will review, and must approve in writing, the draft Cultural Resources Monitoring and Mitigation Plan. The CPM

34 Ibid., page 22, CUL-2. (A full summary of this COC was not included above.) 35 Ibid., page 22, CUL-2. 
will provide copies of the draft plan to Western so that Western may submit this plan to the SHPO for concurrence prior to the project owner taking any actions under the approved monitoring and mitigation plan.

Protocol: The Cultural Resources Monitoring and Mitigation Plan shall include, but not be limited to, the following elements and measures:

1) A discussion of the sequence of project-related tasks, such as any final preproject surveys, fieldwork, flagging or staking; construction monitoring; mapping and data recovery; preparation for recovering cultural resources; preparation of recovered materials for analysis, identification, and inventory; preparation of preliminary and final reports; and preparation of materials for curation.

2) An identification of the person(s) expected to assist with each of the tasks identified in above, a discussion of the mitigation team leadership and organizational structure and the inter-relationship of tasks and responsibilities.

3) When sensitive areas are to be monitored during construction or avoided during operation, the designated cultural resource specialist shall identify measures such as flagging or fencing to prohibit or otherwise restrict access to sensitive resource areas. The discussion should address how these measures will be implemented prior to the start of construction and how long they will be needed to protect the resources from project-related effects.

4) Where the need for monitoring of project construction activities has been determined by Western, the designated cultural resource specialist, in consultation with the CPM, will establish a schedule for the monitor(s) to be present. If the designated cultural resource specialist determines the likelihood of encountering cultural resource or sites in certain areas is slight, monitoring may be discontinued in that location.

5) If cultural resources are encountered are exposed during project-related grading, excavation, augering, and/or trenching, the designated cultural resource specialist shall have the authority to halt or redirect construction in the immediate vicinity of 
the find until the specialist can determine the significance of the find. The designated cultural resource specialist shall act in accordance with the following procedures:

- The project owner, or designated representative, shall inform the CPM and Western within one working day of the discovery of any potentially significant cultural resources and discuss the specific measure(s) proposed to mitigate potential impacts to these resources.

- The designated cultural specialist, representatives of the project owner, Western, and the CPM shall confer within 5 working days of the notification of the CPM, if necessary, to discuss any mitigation measures already implemented or proposed to be implemented, and to discuss the disposition of any finds.

- The SHPO will be consulted on potential eligibility, effect and proposed mitigative measures. As the Federal lead agency, Western will initiate the consultations with the SHPO.

- All required data recovery and cultural resource impact mitigation shall be completed as expeditiously as possible.

6) All isolates encountered will be recorded and mapped; all lithic scatters and/or cultural resource sites will be recorded and mapped, and all diagnostic artifacts will be collected for analysis; and all recovered cultural resource materials will be prepared and delivered for curation into a retrievable storage collection in a public repository or museum that meets the Title 36 CFR 79 standards for the curation of cultural resource materials.

7) The identification of the public institution that has agreed to receive any maps and data, records, reports, and any cultural resource materials recovered during projectrelated monitoring and mitigation work. Also include a discussion of any requirements or specification for materials delivered for curation and how they will 
be met. The name and phone number of the contact person at the institution shall be included as well. ${ }^{36}$

\begin{tabular}{|c|c|}
\hline $\begin{array}{c}\text { COMMISSION } \\
\text { VERIFICATION PROCESS }\end{array}$ & $\begin{array}{l}\text { WESTERN } \\
\text { MONITORING }\end{array}$ \\
\hline $\begin{array}{l}\text { At least } 60 \text { days prior to the start of construction, } \\
\text { the project owner shall provide the CPM and } \\
\text { Western with a copy of the draft Cultural Resources } \\
\text { Monitoring and Mitigation Plan prepared by the } \\
\text { designated cultural resource specialist. The CPM } \\
\text { and Western will provide written approval or } \\
\text { disapproval of the proposed Cultural Resources } \\
\text { Monitoring and Mitigation Plan within } 15 \text { days of } \\
\text { receipt of the submittal. If the draft plan is not } \\
\text { approved, the project owner, the designated cultural } \\
\text { resources specialist, the CPM and Western shall } \\
\text { meet to discuss comments and work out necessary } \\
\text { changes. }\end{array}$ & $\begin{array}{l}\text { At least } 60 \text { days prior to the start of construction, } \\
\text { the project owner shall provide the CPM and } \\
\text { Western with a copy of the draft Cultural Resources } \\
\text { Monitoring and Mitigation Plan prepared by the } \\
\text { designated cultural resource specialist. The CPM } \\
\text { and Western will provide written approval or } \\
\text { disapproval of the proposed Cultural Resources } \\
\text { Monitoring and Mitigation Plan within } 15 \text { days of } \\
\text { receipt of the submittal. If the draft plan is not } \\
\text { approved, the project owner, the designated cultural } \\
\text { resources specialist, the CPM and Western shall } \\
\text { meet to discuss comments and work out necessary } \\
\text { changes. }\end{array}$ \\
\hline
\end{tabular}

\section{N. Development of Cultural Resources Employee Training Program}

Description of Commission Condition of Certification: Prior to the start of construction on the project, the designated cultural resource specialist shall prepare an employee training program. The designated cultural resource specialist shall submit the training program to the CPM and Western for review and written approval.

Protocol: The training program shall address the potential to encounter cultural resources during project-related site preparation and construction activities, the sensitivity and importance of these resources and the legal obligations to preserve and protect such resources.

The training program shall also include the set of reporting procedures workers are to follow if any cultural resources are encountered during project activities. This training program may be combined with other training programs prepared for paleontological and biological resources, hazardous materials, or any other areas of interest or concern. ${ }^{38}$ 


\begin{tabular}{|l|l|}
\hline \multicolumn{1}{|c|}{ COMMISSION } & \multicolumn{1}{|c|}{ WERIFICATION PROCESS } \\
\hline $\begin{array}{l}\text { At least 30 days prior to the start of construction, the } \\
\text { project owner shall submit to the CPM and Western } \\
\text { for review, comment and written approval, the } \\
\text { proposed employee training program and set of } \\
\text { reporting procedures the workers are to follow if } \\
\text { cultural resources are encountered during project } \\
\text { construction. Western may be required to submit } \\
\text { this training plan to the SHPO for concurrence as } \\
\text { part of the consultation process. }\end{array}$ & $\begin{array}{l}\text { At least 30 days prior to the start of construction, the } \\
\text { project owner shall submit to the CPM and Western } \\
\text { for review, comment and written approval, the } \\
\text { proposed employee training program and set of } \\
\text { reporting procedures the workers are to follow if } \\
\text { cultural resources are encountered during project } \\
\text { construction. Western may be required to submit } \\
\text { this training plan to the SHPO for concurrence as } \\
\text { part of the consultation process. }\end{array}$ \\
$\begin{array}{l}\text { The CPM and Western shall provide written } \\
\text { approval or disapproval of the employee training } \\
\text { program and set of procedures within 15 days after } \\
\text { receipt of the submittal. If the draft training program } \\
\text { is not approved, the project owner, the designated } \\
\text { cultural resource specialist, the CPM and Western } \\
\text { shall confer as needed to achieve any necessary } \\
\text { changes. }\end{array}$ & $\begin{array}{l}\text { The CPM and Western shall provide written } \\
\text { approval or disapproval of the employee training } \\
\text { program and set of procedures within 15 days after } \\
\text { receipt of the submittal. If the draft training program } \\
\text { is not approved, the project owner, the designated } \\
\text { cultural resource specialist, the CPM and Western } \\
\text { shall confer as needed to achieve any necessary } \\
\text { changes. }\end{array}$ \\
\hline
\end{tabular}

\section{O. Implementation of Cultural Resources Employee Training Program}

Description of Commission Condition of Certification: Prior to the start of construction, and throughout the project construction period as needed for all new employees, the project owner and the designated cultural resource specialist shall provide the approved training to all project managers, construction supervisors, and workers who operate ground-disturbing equipment. The project owner and construction manager shall provide the workers with the approved set of procedures for reporting any cultural resources discovered during projectrelated ground disturbance. ${ }^{40}$ 


\begin{tabular}{|c|c|}
\hline $\begin{array}{l}\text { COMMISSION } \\
\text { VERIFICATION PROCESS }\end{array}$ & \begin{tabular}{c} 
WESTERN \\
\hdashline$\quad$ MONIORING
\end{tabular} \\
\hline $\begin{array}{l}\text { Prior to the start of construction, and throughout the } \\
\text { project construction period as needed for all new } \\
\text { employees, the project owner and the designated } \\
\text { cultural resource specialist shall present the CPM- } \\
\text { and Western-approved training program on the } \\
\text { potential for project impacts to sensitive cultural } \\
\text { resources. The training shall include a set of } \\
\text { reporting procedures for cultural resources } \\
\text { encountered during project activities. The project } \\
\text { owner shall provide documentation in the monthly } \\
\text { compliance report to the CPM that the employee } \\
\text { training and the set of procedures have been } \\
\text { provided to all project managers, construction } \\
\text { supervisors and to all workers. }{ }^{41}\end{array}$ & $\begin{array}{l}\text { Calpine shall provide documentation (e.g., a list of } \\
\text { names, instructor, date completed) containing the } \\
\text { names of persons who have completed the training to } \\
\text { Western on a quarterly basis. }\end{array}$ \\
\hline
\end{tabular}

\section{P. Cultural Resources Reporting-1}

Description of Commission Condition of Certification: Throughout the project construction period, the project owner shall provide the designated cultural resource specialist with a current schedule of weekly project activity and a map indicating the area(s) where construction activities will occur. The designated cultural resource specialist shall consult daily with the project superintendent or construction field manager to confirm the area(s) to be worked on the next day(s).

Throughout the monitoring and mitigation phase of the project, the designated cultural resource specialist shall maintain a daily log of monitoring and mitigation activities carried out by the specialist and members of the cultural resource mitigation team. The designated cultural resource specialist shall prepare summary reports on monitoring activities, any cultural resource finds and recovery efforts and the progress or status of the resource monitoring, mitigation, preparation, identification, and analytical work being conducted for the project. Copies of these summaries shall be included in the monthly compliance reports file with CPM by the project owner. The CPM will forward copies of these summary reports to Western. The designated cultural resource specialist may informally discuss the cultural resource monitoring and mitigation activities with their Commission technical counterpart at any time.

41 Ibid. 


\begin{tabular}{|l|l|}
\hline \multicolumn{1}{|c|}{ COMMISSION } & \multicolumn{1}{|c|}{ WESTERN } \\
VERICICATION PROCESS & \multicolumn{1}{|c|}{} \\
\hline $\begin{array}{l}\text { The project owner shall include, in the monthly } \\
\text { compliance reports to the CPM, a summary of the } \\
\text { daily logs prepared by the designated cultural } \\
\text { resource specialist; the CPM will forward copies to } \\
\text { Western. }\end{array}$ & $\begin{array}{l}\text { Calpine shall inform Western of any cultural resource } \\
\text { finds and recovery efforts, as needed. }\end{array}$ \\
\hline
\end{tabular}

\section{Q. Cultural Resources Reporting-2}

Description of Commission Condition of Certification: The designated cultural resource specialist shall be present at the construction site at all times when construction-related grading, excavation, trenching and/or auguring occurs in areas that lie within the natural river levee zone (found to be generally associated with the Shanghai-Nueva-Columbia soils group). Project areas where the natural levee zones may be found include the switchyard site and portions of the 16 -inch and the 4-inch natural gas pipeline routes. Using the mile posts and boundary stakes placed by the project owner, the designated cultural resource specialist shall monitor the route of the 16-inch natural gas pipeline, between Mile Post (MP) 8.97 to 9.51; MP 10.42 to MP 11.41 and MP 12.1 to 13.70. For the route of the 4-inch natural gas pipeline, areas to be monitored full time are from MP 0.00 to MP 1.60. Other sections of the linear facility routes may be monitored as deemed necessary by the CPM and Western. ${ }^{43}$

\begin{tabular}{|l|c|}
\hline \multicolumn{1}{|c|}{ COMMISSION } & \multicolumn{1}{|c|}{ WESTERN } \\
\hline VERIFICATION PROCESS & MONITORING
\end{tabular}

\section{R. Discovery of Human Remains}

Description of Commission Condition of Certification: If human remains are encountered during project-related grading, excavation, auguring, and/or trenching, the construction crew shall halt or redirect construction in the immediate vicinity of the find and immediately 
contact the county coroner and the designated cultural resource specialist. If the coroner determines that the find is of Native American origin, the coroner shall notify the Native American Heritage Commission (NAHC) to request a determination of "most likely descendant." The NAHC is required to notify the descendant(s) and request that they inspect the burial and make recommendations for treatment or disposal. If Native American remains are encountered on Federally managed land (within the Sutter National Wildlife Reserve), the USFWS is required to follow the procedures of the Native American Graves Protection and Repatriation Act, to repatriate the remains.

\begin{tabular}{|l|l|}
\hline \multicolumn{1}{c|}{ COMMISSION } & \multicolumn{1}{|c|}{ MESTERN } \\
\hline $\begin{array}{l}\text { The designated cultural resource specialist shall } \\
\text { notify the county coroner, the project owner, the } \\
\text { CPM and Western if any buried human remains are } \\
\text { encountered during project construction activities. }\end{array}$ & $\begin{array}{l}\text { If human remains are discovered and determined to } \\
\text { be of Native American origin, Western will consult } \\
\text { with the CPM and the designated cultural resource } \\
\text { specialist for the proper disposition of the remains. }\end{array}$ \\
\hline
\end{tabular}

\section{S. Preliminary Cultural Resources Report}

Description of Commission Condition of Certification: $T$ he project owner shall ensure preparation of a preliminary cultural resources report following completion of data recovery and site mitigation work. The preliminary report is to be prepared by the designated cultural resource specialist and submitted to the CPM and Western for review and written approval. Western will provide copies of the preliminary report to the SHPO.

Protocol: The preliminary report shall include (but not be limited to) preliminary information on the survey report(s), methodology and recommendations; site records and maps; determinations of significance; data recovery and other mitigation activities; discussion of possible results and findings of any analysis to be conducted on recovered cultural resource materials and data; proposed research questions that may be answered, or that may have been raised by the data from the project-related information such as maps, diagrams, charts, photographs and other appropriate materials; and an estimate of the time needed to complete the analysis of recovered cultural resource materials and prepare a final 
report. As the Federal lead agency, Western will provide a standard report format to be followed by the designated cultural resource specialist.

If no cultural resource materials are recovered during project-related construction activities, the approved preliminary report shall also serve as the final report and shall be filed with appropriate entities. ${ }^{46}$

\begin{tabular}{|l|l|}
\hline \multicolumn{1}{|c|}{ COMMISSION } & \multicolumn{1}{|c|}{\begin{tabular}{c}
\multicolumn{1}{|c|}{ WERTEICATION PROCESS } \\
MONITORING
\end{tabular}} \\
\hline $\begin{array}{l}\text { Within 90 days following completion of the data } \\
\text { recovery and site mitigation work, the project owner } \\
\text { shall submit a copy of the preliminary cultural } \\
\text { resources report to the CPM and to Western for } \\
\text { review, comment and written approval. }\end{array}$ & $\begin{array}{l}\text { Western will recommend a standard report format to } \\
\text { be followed by the designated cultural resource } \\
\text { specialist in preparing the preliminary cultural } \\
\text { resources report. Western will provide the } \\
\text { recommended format to the designated cultural } \\
\text { resource specialist upon request and prior to report } \\
\text { preparation. Western will review the preliminary } \\
\text { cultural resources report (and final cultural resources } \\
\text { report, if necessary) and provide written comment } \\
\text { and approval or disapproval of the report. }\end{array}$ \\
\hline
\end{tabular}

\section{T. Final Cultural Resources Report}

Description of Commission Condition of Certification: The project owner will ensure preparation of a final cultural resources report by the designated cultural resource specialist if cultural resource materials are found and recovered during project-related monitoring and mitigation. This final report shall be submitted to the CPM and Western for review and written approval.

Protocol: The final report shall include (but not be limited to) the survey report(s), methodology and recommendations; site records and maps; description and inventory list of recovered cultural resource materials; determinations of sensitivity and significance; summary of data recovery and other mitigation activities; results and findings of any special analyses conducted on recovered cultural resource materials and data; research questions answered or raised by the data from the project; and the name and location of the public institution receiving the recovered cultural resource materials for curation. As the lead

46 SPP Final EIS, Appendix O, page 25, CUL-11. (A full summary of this COC was not included above.) 47 Ibid. 
Federal agency, Western will provide a standard report format to be followed by the designated cultural resource specialist. ${ }^{48}$

\begin{tabular}{|l|l|}
\hline \multicolumn{1}{|c|}{ COMMISSION } & \multicolumn{1}{|c|}{ VERIFICATION PROCESS } \\
\hline $\begin{array}{l}\text { The project owner shall submit a copy of the draft } \\
\text { final cultural resources report to the CPM and } \\
\text { Western for review, comment, and written approval. } \\
\begin{array}{l}\text { The report shall be submitted to the CPM and } \\
\text { Western within 90 days following completion of the } \\
\text { analysis of the recovered cultural materials and } \\
\text { preparation of related information. The project } \\
\text { owner shall submit a copy of the final cultural } \\
\text { resources report to the CPMand Westem for review and } \\
\text { witten approval }\end{array}\end{array}$ & $\begin{array}{l}\text { Western will review the draft final cultural resources } \\
\text { report (as well as the final report) and provide written } \\
\text { comment, and approval or disapproval of the report. }\end{array}$ \\
\hline
\end{tabular}

\section{U. Cultural Resource Recovery Documentation}

Description of Commission Condition of Certification: The project owner shall ensure that Western is provided with an original (or original-quality) copy of the approved final cultural resources report, and other copies necessary to submit to the public institution receiving the recovered data and materials for curation, to the SHPO, and to the appropriate regional archaeological information center(s). A legible copy of the approved final cultural resource report shall be filed with the CPM, with a request for confidentiality, if needed to protect any sensitive resources or sites.

The report copy sent to the curating institution and to the appropriate regional information centers shall include the information required by 36 CFR 79 and the regional archaeological information centers. ${ }^{50}$

\begin{tabular}{|l|l|}
\hline \multicolumn{1}{|c|}{ COMMISSION } & \multicolumn{1}{|c|}{$\begin{array}{l}\text { VERTERN } \\
\text { VERICATION PROCESS }\end{array}$} \\
\hline $\begin{array}{l}\text { The project owner shall maintain in its compliance } \\
\text { files, copies of all documentation related to the } \\
\text { original materials and the approved final cultural } \\
\text { resources report with the public institution receiving } \\
\text { the recovered data and materials for curation, with the } \\
\text { appropriate regional archaeological information } \\
\text { repository (ies) and the SHPO. If no cultural resource }\end{array}$ & $\begin{array}{l}\text { If cultural resources are recovered, Western will } \\
\text { coordinate the report with the SHPO and other } \\
\text { agencies, as appropriate. }\end{array}$ \\
\hline
\end{tabular}

48 Ibid., page 25, CUL- 12.

49 SPP Final EIS, Appendix O, page 25, CUL-12.

50 Ibid., page 25 , CUL-13. 


\begin{tabular}{|c|c|}
\hline $\begin{array}{c}\text { COMMISSION } \\
\text { VERIFICATION PROCESS }\end{array}$ & $\therefore \quad \begin{array}{l}\text { WESTERN } \\
\text { MONITORING }\end{array}$ \\
\hline $\begin{array}{l}\text { materials were recorded or recovered, then the } \\
\text { approved preliminary cultural resources report shall } \\
\text { serve as the final report and is to be filed with these } \\
\text { same agencies.51 }\end{array}$ & \\
\hline
\end{tabular}

PALEONTOLOGICAL RESOURCES

\section{Designation of Paleontological Resource Specialist}

Description of Commission Condition of Certification: Prior to the start of project construction (defined as any construction-related vegetation clearance, ground disturbance and preparation, and site excavation activities), the project owner shall provide the CPM with the name(s) and qualifications of its designated paleontologic resources specialists and mitigation team members.

The designated paleontologic resources specialist shall be responsible for implementing all the Conditions of Certification and for using qualified personnel to assist him or her in project-related field surveys; monitoring; fossil stabilization, removal, and transport; data collection and mapping; direction and implementation of mitigation procedures; matrix sampling; screen washing and other micro-fossil recovery techniques; preparation and analysis of recovered fossils and data; identification and inventory of analysis of recovered fossils; preparation of recovered fossils for delivery and curation; and report preparation.

After CPM approval of the paleontologic resources monitoring and mitigation plan, described below in Condition PAL-4, the designated paleontologic resources specialist and team shall be available to implement the mitigation plan prior to and throughout project construction.

Protocol: The project owner shall provide the CPM with a resume or statement of qualifications for its designated paleontologic resources specialist and mitigation team members. The resume(s) shall include the following information:

1) The resume for the designated paleontologic resource specialist shall demonstrate the specialist meets the following minimum qualifications: a graduate degree in paleontology or geology or paleontologic resource management; at least three years 
of paleontologic resource mitigation and field experience in California, including at least one year's experience leading paleontologic resource field surveys; leading site mapping and data recording; marshalling and using of equipment necessary for fossil recovery, sampling, and screen washing; leading fossil recovery operations; preparing recovered materials for analysis and identification; recognizing the need for appropriate sampling and/or testing in the field and in the lab; directing the analyses of mapped and recovered fossil materials; completing the identification and inventory of recovered fossil materials; and the preparation of appropriate reports to be filed with the receiving curation repository, the University Museum of Paleontology at Berkeley, all appropriate regional information center(s) and the Commission.

2) The resume for the designated paleontologic resource specialist shall include a list of specific projects the specialist has previously worked on; the role and responsibilities of the specialist for each project listed; and the names and phone numbers of contacts familiar with the specialist's work on these referenced projects.

3) If additional personnel will be assisting the designated paleontologic resources specialist in project-related field surveys, monitoring, data and fossil recovery, mapping, mitigation, fossil analysis or report preparation, the project owner shall also provide names, addresses and resumes for these paleontology resource team members.

4) If the CPM determines the qualifications of the proposed paleontologic resources specialist do not meet the above requirements, the project owner shall submit another individual's name and qualifications for consideration. 
If the previously approved designated paleontologic resources specialist is replaced prior to completion of project mitigation, the project owner shall obtain CPM approval of the new designated paleontologic resources specialist by submitting the name and qualifications of the proposed replacement to the CPM, at least 10 days prior to the termination or release of the preceding designated paleontologic resources specialist. ${ }^{52}$

\begin{tabular}{|l|l|}
\hline \multicolumn{1}{|c|}{ COMMISSION } & \multicolumn{1}{|c|}{ VERIFICATION PROCESS } \\
\hline $\begin{array}{l}\text { At least } 90 \text { days prior to the start of construction on } \\
\text { the project, the project owner shall submit the names } \\
\text { and resume for its designated paleontologic resources } \\
\text { specialist to the CPM for review and approval. The } \\
\text { CPM shall provide written approval or disapproval of } \\
\text { the proposed paleontologic resources specialist. } \\
\text { Thirty days prior to the start of the construction, the } \\
\text { project owner shall confirm in writing to the CPM } \\
\text { that the previously approved, designated } \\
\text { paleontologic resources specialist and the team of } \\
\text { assistants are prepared to implement the monitoring } \\
\text { and mitigation measures for paleontologic resources, } \\
\text { as described in the CPM-approved paleontologic } \\
\text { resources monitoring and mitigation plan, prepared } \\
\text { per Condition PAL-4 below. } \\
\text { At least } 10 \text { days prior to the termination or release of } \\
\text { a designated paleontologic resource specialist, the } \\
\text { project owner shall obtain CPM approval of the new } \\
\text { designated paleontologic resource specialist by } \\
\text { submitting to the CPM the name and resume of the } \\
\text { proposed replacement specialist. }\end{array}$ \\
\hline
\end{tabular}

\section{W. Paleontological Resources Training Program}

Description of Commission Condition of Certification: Prior to the start of construction on the project, the designated paleontologic resources specialist shall prepare an employee training program. The designated paleontologic resource specialist shall submit the training program to the CPM for approval.

Protocol: The training program will discuss the potential for encountering fossil resources, the sensitivity and importance of these resources, and the legal obligations to preserve and protect such resources. 
The training shall also include the set of reporting procedures that workers will follow if sensitive paleontologic resources are encountered during project activities. The training program will be presented by the designated paleontologic resources specialist and may be combined with other training programs prepared for cultural and biological resources, hazardous materials, or any other areas of interest or concern. ${ }^{54}$

\begin{tabular}{|c|c|}
\hline COMMISSION & $\begin{array}{ccc}\text { WESTERN } & \\
\text { MONITORING } & \\
\end{array}$ \\
\hline $\begin{array}{l}\text { At least } 30 \text { days prior to the start of construction, the } \\
\text { project owner shall submit to the CPM for review, } \\
\text { comment and written approval, the proposed } \\
\text { employee training program and set of reporting } \\
\text { procedures the workers are to follow if paleontologic } \\
\text { resources are encountered during project } \\
\text { construction. } \\
\text { The CPM shall provide the project owner with } \\
\text { written approval or disapproval of the employee- } \\
\text { training program and the set of procedures within } 15 \\
\text { days of receipt of the submittal. If the draft-training } \\
\text { program is not approved, the project owner, the } \\
\text { designated paleontologic resources specialist and the } \\
\text { CPM shall meet to discuss the comments and work } \\
\text { out necessary changes. }\end{array}$ & $\begin{array}{l}\text { Calpine will provide Western with a copy of the } \\
\text { CPM-approved paleontology training program prior } \\
\text { to implementation. }\end{array}$ \\
\hline
\end{tabular}

\section{Final Paleontological Resources Report}

Description of Commission Condition of Certification: The project owner shall ensure preparation of a final paleontologic resources report by the designated paleontologic resources specialist if significant fossil resources are found and recovered during projectrelated surveys, monitoring and mitigation.

Protocol: The final report shall include (but not be limited to) the survey report(s), methodology and recommendations; locality records and maps; description and inventory list of recovered fossil materials; determinations of sensitivity and significance; summary of data recovery and other mitigation activities; results and findings of any special analyses conducted on recovered paleontologic resource materials and data; research questions 
answered or raised by the data form the project; and the name and location of the public institution receiving the recovered paleontologic resources for curation. ${ }^{56}$

\begin{tabular}{|l|c|}
\hline \multicolumn{1}{|c|}{ COMMISSION } & \multicolumn{1}{|c|}{$\begin{array}{c}\text { WESTERN } \\
\text { MENITORING }\end{array}$} \\
\hline $\begin{array}{l}\text { The project owner shall submit a copy of the draft } \\
\text { final paleontologic resources report to the CPM for } \\
\text { review, comment and written approval. The draft } \\
\text { final paleontologic resources report shall be } \\
\text { submitted to the CPM within 90 days after } \\
\text { completing analysis of the recovered fossil materials } \\
\text { and preparing text and related information, such as } \\
\text { maps, diagrams, tables, charts, photos, etc. }\end{array}$ & $\begin{array}{l}\text { Calpine shall provide Western with a copy of the } \\
\text { final paleontological resources report. }\end{array}$ \\
\hline
\end{tabular}

\section{FACILITY DESIGN}

\section{Y. Designated Resident Engineer and other Key Personnel}

Description of Commission Condition of Certification: Prior to the start of site preparation, the project owner shall assign a California registered architect, structural engineer or civil engineer, as a resident engineer (RE), to be in general responsible charge of the project. [Building Standards Administrative Code (part 1, title 24, C.C.R.), Section 4-209 - Designation of Responsibilities.]

The RE may delegate responsibility for portions of the project to other registered engineers. Registered mechanical and electrical engineers may be delegated responsibility for mechanical and electrical portions of the project, respectively. A project may be divided into parts, provided each part is clearly defined as a distinct unit. Separate assignment of general responsible charge may be made for each designated part.

Protocol: The RE shall:

1) Monitor construction progress to ensure compliance with the design intent;

2) Ensure construction of all the facilities conforms, in every material respect, to the applicable laws, ordinances, regulations and standards (LORS), approved plans and specifications; 
3) Prepare documents to initiate changes in approved drawings and specifications when directed by the project owner or as required by conditions on the project;

4) Be responsible for providing the project inspectors and testing agency(ies) with complete and up-to-date set(s) of stamped drawings, plans, specifications and other required documents;

5) Be responsible for the timely submittal of construction progress reports to the chief building official (CBO) from the project inspectors, the contractor and other engineers who have been delegated responsibility for portions of the project; and

6) Be responsible for notifying the $\mathrm{CBO}$ of corrective action or the disposition of items noted on laboratory reports or other tests as not conforming to the approved plans and specifications.

The RE shall have the authority to halt construction and to require changes or remedial work if the work does not conform to applicable requirements. (FACILITY DESIGN 516 October 19, 1998.)

If the $\mathrm{RE}$ or the delegated engineers are reassigned or replaced, the project owner shall submit the name, qualifications and registration number of the newly assigned engineer to the $\mathrm{CBO}$ for review and approval. The project owner shall notify the CPM of the CBO approval of the new engineer. ${ }^{58}$

\begin{tabular}{|l|l|}
\hline & \multicolumn{1}{c}{ COMMISSION } \\
\hline AERIFICATION PROCESS & \\
\hline $\begin{array}{l}\text { At least } 30 \text { days (or a lesser number mutually agreed } \\
\text { to by the project owner and the CBO) prior to the } \\
\text { start of rough grading, the project owner shall submit to } \\
\text { the CBO for review and approval, the name, qualifications } \\
\text { and registration number of the RE and any other } \\
\text { delegated engineers assigned to the project. The } \\
\text { project owner shall notify the CPM of the CBO's approvals } \\
\text { of the RE and other delegated engineer(s) within five days of } \\
\text { the approval. If the RE or the delegated engineer(s) are } \\
\text { subsequently reassigned or replaced, the project owner has } \\
\text { five days in which to submit the name, qualifications, and } \\
\text { registration number of the newly assigned engineer to the }\end{array}$ & \\
\hline
\end{tabular}

58 SPP Final EIS, Appendix O, page 32, GEN-4. 
CBO for review and approval. The project owner shall notify the CPM of the CBO's approval of the new engineer within five days of the approval. ${ }^{59}$

59 Ibid.

C-39 


\author{
APPENDIX D \\ REPORT ON THE \\ MITIGATION ACTION PLAN \\ FOR THE \\ GRIFFITH POWER PLANT
}




\section{Mitigation Action Plan \\ For the \\ Griffith Energy Project}

\subsection{INTRODUCTION}

In March 1999, the U.S. Department of Energy (DOE), Western Area Power Administration (Western) distributed the Final Environmental Impact Statement for the Griffith Energy Project, DOE/EIS-0297. The Draft and Final EIS identifies potential adverse effects resulting from the Griffith Energy Project and discusses measures that Western will employ to mitigate potential adverse effects.

Western's Administrator signed the Record of Decision (ROD) on May 12, 1999. Western decided to enter into interconnection and construction agreements with Griffith Energy Limited Liability Corporation (Griffith) to provide the Griffith Power Plant interconnections with Western's Pacific Northwest-Pacific Southwest Intertie and Parker-Davis transmission systems, and to construct and operate transmission system additions to provide the interconnection with its transmission system. The interconnection to Western's transmission system will be provided via two new 230-kilovolt $(\mathrm{kV})$ transmission lines, a new 230-/345-kV substation, and the upgrading of the existing Davis-Prescott 230-kV transmission line. The ROD also identified specific mitigation actions that will implemented as part of the project.

The DOE requirements for preparing a Mitigation Action Plan (MAP) are specified in 10 CFR 1021(Section 331(a), National Environmental Policy Act Implementing Procedures). These guidelines state that following completion of each EIS and its associated ROD, DOE shall prepare a MAP that addresses mitigation commitments expressed in the ROD. The MAP shall explain how the corresponding mitigation measures, designed to mitigate adverse environmental 
impacts associated with the course of action directed by the ROD, will be planned and implemented.

This MAP addresses the Peacock Substation, the new 230-kV transmission lines, the improvement of the existing Davis-Peacock 230-kV transmission line, and mitigation commitments made by Western for the Griffith Power Plant.

\subsection{FUNCTION AND ORGANIZATION OF THE MITIGATION ACTION PLAN}

The following sections describe the plans and actions by which Western will implement and verify mitigation action commitments expressed in the ROD.

Section 3.0 describes the monitoring and verification of mitigation actions and the reporting requirements. Section 4.0 describes the mitigation commitments and action plans for the Peacock Substation and the transmission line components, and the Griffith Power Plant. The commitment to the mitigation specified in the ROD is presented along with an action plan composed of the tasks, responsible party, and schedule anticipated for the mitigation.

\subsection{MITIGATION ACTION PLAN MONITORING AND REPORTING SYSTEM} Section 5.d.(11)(f) of DOE Order 451.1A, National Environmental Policy Act Compliance Program, requires Western to report MAP activities in its Annual Site Environmental Report, published by January 31 of each year. This annual report will reflect new information or changed circumstances. If major changes to mitigation included in this MAP are necessary, these changes will be described in the annual report. The annual report will be made available to the public and posted on Western's web site.

A member of Western's environmental staff will verify mitigation results and determine if the mitigation action achieved its intended purpose. Existing organizational and administrative 
controls will be used to gather information regarding implementation and status of mitigation actions. Such controls include applicable reporting systems, inspection, and verification. The results of inspection and verification will be reported on the anniversary of the Mitigation Action Plan in the annual report. When mitigation actions are completed and verified, the information will be included in the annual report.

Mitigation may also be monitored in accordance with Western's Standard Mitigation Measures.

Griffith Energy has secured or will secure permits required by applicable Federal, State, and local environmental laws, orders, and regulations. For purposes of the MAP, the mitigation conditions set in the permits issued for the project are not addressed in this MAP, unless noted.

\subsection{MITIGATION COMMITMENTS AND ACTION PLANS}

Peacock Substation will be constructed on about 10 acres of land acquired from a private party. The substation will be located near the intersection of the Davis-Prescott 230-kV and MeadLiberty 345-kV transmission lines in N.E. corner of Section 36, Township 22 North, Range 14 West, about 16 miles east of Kingman, Arizona. An existing road will be upgraded to provide vehicle and equipment access into the substation site.

Generic mitigation practices were defined for the new transmission line components, including the Peacock Substation. The generic mitigation practices were considered as impacts were assessed for the transmission components of the project. In some instances, environmental impacts were reduced with the employment of these mitigation measures. Western adopted the generic mitigation measures in its ROD. The MAP will ensure the generic mitigation practices are implemented. 
The implementation of applicable generic mitigation measures for the construction and operation of the substation and transmission line components are presented in Table 4.1. The action plan for specific mitigation measures committed in the EIS for the substation and transmission line components are presented in Table 4.2. Lastly, Table 4.3 is the action plan for mitigation that Western committed to for the Griffith Power Plant. 
Table 4.1: Action Plan for Applicable Generic Mitigation Measures for Peacock Substation, New Transmission Lines and Davis-Peacock Improvements.

\begin{tabular}{|c|c|c|c|c|c|}
\hline \multirow[b]{2}{*}{ Generic and/or Selective Mitigation Commitment } & \multirow[b]{2}{*}{$\begin{array}{c}\text { Responsible } \\
\text { Party }\end{array}$} & \multirow[b]{2}{*}{ Action } & \multicolumn{3}{|c|}{ Target Completion Date } \\
\hline & & & Peacock Sub & New TL's & $\begin{array}{l}\text { Davis-Peacock } \\
\text { Improvements }\end{array}$ \\
\hline $\begin{array}{l}\text { 1. All construction vehicle movement outside the } \\
\text { ROW normally would be restricted to predesignated } \\
\text { access, contractor acquired access, or public roads. } \\
\text { No widening or upgrading of existing access roads } \\
\text { would be undertaken in the area of construction and } \\
\text { operation, except for repairs necessary to make roads } \\
\text { passable, where soils or vegetation are very sensitive } \\
\text { to disturbance. }\end{array}$ & $\begin{array}{l}\text { G5600 } \\
\text { G5600 } \\
\text { G5600/G0400 }\end{array}$ & $\begin{array}{l}\text { Task a: Incorporate requirement into } \\
\text { construction specification } \\
\text { Task b: Advise construction contractor } \\
\text { Task c: Monitor site work }\end{array}$ & $\begin{array}{l}\text { Complete } \\
\text { Complete } \\
12 / 99-02 / 00\end{array}$ & $\begin{array}{l}\text { Complete } \\
02 / 00 \\
02 / 00-09 / 00\end{array}$ & $\begin{array}{l}06 / 00 \\
10 / 00 \\
10 / 00-02 / 01\end{array}$ \\
\hline $\begin{array}{l}\text { 2. The limits of construction activities normally } \\
\text { would be predetermined, with activity restricted to } \\
\text { and confined within those limits. No paint or } \\
\text { permanent discoloring agents would be applied to } \\
\text { rocks or vegetation to indicate limits of survey or } \\
\text { construction activity. There will be no blading of } \\
\text { new access roads unless approved by Western and } \\
\text { the land management agency. }\end{array}$ & $\begin{array}{l}\text { G5600 } \\
\text { G5600 } \\
\text { G5600/G0400 }\end{array}$ & $\begin{array}{l}\text { Task a: Incorporate requirement into } \\
\text { construction specification } \\
\text { Task b: Advise construction contractor } \\
\text { Task c: Monitor site work }\end{array}$ & $\begin{array}{l}\text { Complete } \\
\text { Complete } \\
12 / 99-02 / 00\end{array}$ & $\begin{array}{l}\text { Complete } \\
02 / 00 \\
02 / 00-09 / 00\end{array}$ & $\begin{array}{l}06 / 00 \\
10 / 00 \\
10 / 00-02 / 01\end{array}$ \\
\hline $\begin{array}{l}\text { 3. In construction areas where recontouring is not } \\
\text { required, vegetation would be left in place wherever } \\
\text { possible and original contour would be maintained to } \\
\text { avoid excessive root damage and allow for } \\
\text { resprouting. }\end{array}$ & $\begin{array}{l}\text { G5600 } \\
\text { G5600 } \\
\text { G5600/G0400 }\end{array}$ & $\begin{array}{l}\text { Task a: Incorporate requirement into } \\
\text { construction specification } \\
\text { Task b: Advise construction contractor } \\
\text { Task c: Monitor site work }\end{array}$ & $\begin{array}{l}\text { Complete } \\
\text { Complete } \\
12 / 99-02 / 00 \\
\end{array}$ & $\begin{array}{l}11 / 99 \\
02 / 00 \\
02 / 00-09 / 00 \\
\end{array}$ & $\begin{array}{l}06 / 00 \\
10 / 00 \\
10 / 00-02 / 01\end{array}$ \\
\hline $\begin{array}{l}\text { 4. In construction areas (e.g., marshaling yards, tower } \\
\text { sites, spur roads from existing access roads) where } \\
\text { ground disturbance is substantial or where } \\
\text { recontouring is required, surface restoration would } \\
\text { occur as required by the landowner or land } \\
\text { management agency. The method of restoration } \\
\text { normally would consist of returning disturbed areas } \\
\text { back to their natural contour, reseeding (if required), }\end{array}$ & $\begin{array}{l}\text { G0400 } \\
\text { G0400/G5600 } \\
\text { Lands }\end{array}$ & $\begin{array}{l}\text { Task a: Prepare construction operation and } \\
\text { maintenance plan } \\
\text { Task b: Coordinate restoration activities with } \\
\text { BLM. } \\
\text { Task c: Determine landowner restoration }\end{array}$ & N/A & $\begin{array}{l}06 / 99-12 / 99 \\
10 / 99-12 / 99 \\
9 / 99-12 / 99\end{array}$ & $\begin{array}{l}\text { N/A } \\
02 / 00-04 / 00 \\
02 / 00-04 / 00\end{array}$ \\
\hline
\end{tabular}




\begin{tabular}{|c|c|c|c|c|c|}
\hline & & & \multicolumn{3}{|c|}{ Target Completion Date } \\
\hline Generic and/or Selective Mitigation Commitment & $\begin{array}{l}\text { Responsible } \\
\text { Party }\end{array}$ & Action & Peacock Sub & New TL's & $\begin{array}{l}\text { Davis-Peacock } \\
\text { Improvements }\end{array}$ \\
\hline $\begin{array}{l}\text { installing cross drains for erosion control, placing } \\
\text { water bars in the road, and filling ditches. To avoid } \\
\text { fragmentation of desert bighorn habitat, fencing } \\
\text { would not be used to close roads or otherwise limit } \\
\text { access. Any new access roads not required for } \\
\text { maintenance would be permanently closed using the } \\
\text { most effective and least environmentally damaging } \\
\text { methods appropriate to that area with concurrence of } \\
\text { the landowner or land manager. These instances } \\
\text { would be reviewed on a case-by-case basis. }\end{array}$ & $\begin{array}{l}\text { G5600 } \\
\text { G5600 }\end{array}$ & $\begin{array}{l}\text { needs } \\
\text { Task d: Incorporate requirements into } \\
\text { construction contract } \\
\text { Task e: Monitoring }\end{array}$ & N/A & $\begin{array}{l}11 / 99-12 / 99 \\
02 / 00-09 / 00\end{array}$ & $\begin{array}{l}06 / 00 \\
10 / 00-02 / 01\end{array}$ \\
\hline $\begin{array}{l}\text { 5. Watering facilities and other range improvements } \\
\text { would be repaired or replaced, if they are damaged or } \\
\text { destroyed by construction activities, to their } \\
\text { condition prior to disturbance as agreed to by the } \\
\text { parties involved. }\end{array}$ & G5600 & Task a: Post-Construction Review & N/A & $09 / 00$ & $10 / 00$ \\
\hline $\begin{array}{l}\text { 6. Towers and/or ground wire would be marked with } \\
\text { highly visible devices where required by } \\
\text { governmental agencies (e.g., Federal Aviation } \\
\text { Administration) for aircraft safety. }\end{array}$ & $\begin{array}{l}\mathrm{A} 3900 \\
\mathrm{G} 5600\end{array}$ & $\begin{array}{l}\text { Task a: Determine need for marking } \\
\text { Task b: Install markers, if required }\end{array}$ & N/A & $\begin{array}{l}\text { Complete } \\
03 / 00-09 / 00\end{array}$ & $\begin{array}{l}02 / 00-04 / 00 \\
10 / 00-02 / 01\end{array}$ \\
\hline $\begin{array}{l}\text { 7. Prior to construction, all supervisory construction } \\
\text { personnel would be instructed on measures to protect } \\
\text { cultural, paleontological, and ecological resources. }\end{array}$ & G5600/G0400 & $\begin{array}{l}\text { Task a: Advise construction contractor at } \\
\text { preconstruction conference }\end{array}$ & Complete & $02 / 00$ & $10 / 00$ \\
\hline $\begin{array}{l}\text { 8. Cultural resources would continue to be } \\
\text { considered during post-EIS phases of Project } \\
\text { implementation in accordance with the programmatic } \\
\text { agreement that is being developed in conjunction } \\
\text { with preparation of the EIS. }\end{array}$ & G0400/A3400 & $\begin{array}{l}\text { Task a: Conduct intensive survey } \\
\text { Task b: Conduct ethnographic study } \\
\text { Task c: Consult with tribes } \\
\text { Task d: Consult with SHPO } \\
\text { Task e: Determine project modifications }\end{array}$ & $\begin{array}{l}\text { Complete } \\
\text { Complete } \\
\text { Complete } \\
\text { Complete } \\
\text { Complete }\end{array}$ & $\begin{array}{l}\text { Complete } \\
\text { Complete } \\
\text { Complete } \\
01 / 00-02 / 00 \\
12 / 99-01 / 00\end{array}$ & $\begin{array}{l}\text { Complete } \\
\text { Complete } \\
\text { Complete } \\
01 / 00-02 / 00 \\
02 / 00-04 / 00\end{array}$ \\
\hline
\end{tabular}




\begin{tabular}{|c|c|c|c|c|c|}
\hline \multirow[b]{2}{*}{ Generic and/or Selective Mitigation Commitment } & \multirow[b]{2}{*}{$\begin{array}{c}\text { Responsible } \\
\text { Party }\end{array}$} & \multirow[b]{2}{*}{ Action } & \multicolumn{3}{|c|}{ Target Completion Date } \\
\hline & & & Peacock Sub & New TL's & $\begin{array}{l}\text { Davis-Peacock } \\
\text { Improvements } \\
\end{array}$ \\
\hline & G0400/G5600 & $\begin{array}{l}\text { Task f: Construction monitoring (Not } \\
\text { required, unless arch. resources discovered) }\end{array}$ & Not required & $03 / 00-09 / 00$ & $10 / 00-02 / 01$ \\
\hline $\begin{array}{l}\text { 9. Western would respond to individual complaints } \\
\text { of radio or television interference generated by the } \\
\text { transmission line by investigating the complaints and } \\
\text { implementing appropriate mitigation measures (e.g., } \\
\text { adjusting or using filtering devices on antennae). } \\
\text { The transmission line would be patrolled on a } \\
\text { regular basis so that damaged insulators or other } \\
\text { transmission line materials, which could cause } \\
\text { interference, are repaired or replaced. }\end{array}$ & G5000 & $\begin{array}{l}\text { Task a: Respond to complaints } \\
\text { Task b: Transmission line } \\
\text { Patrols } \\
\text { Task c: Replace damaged insulators or } \\
\text { conductor }\end{array}$ & Not applicable & $\begin{array}{l}\text { On-going } \\
\text { Quarterly } \\
\text { As required }\end{array}$ & $\begin{array}{l}\text { On-going } \\
\text { Quarterly } \\
\text { As required }\end{array}$ \\
\hline $\begin{array}{l}\text { 10. Western would apply mitigation needed to } \\
\text { eliminate problems of induced currents and voltages } \\
\text { onto conductive objects sharing a ROW to the mutual } \\
\text { satisfaction of the parties involved. }\end{array}$ & G5000 & Task a: Respond to complaints & Not applicable & On-going & On-going \\
\hline $\begin{array}{l}\text { 11. Western would continue to monitor studies } \\
\text { performed to determine the effects of audible noise } \\
\text { and electrostatic and electric magnetic fields to } \\
\text { ascertain whether these effects are significant. }\end{array}$ & G0400 & $\begin{array}{l}\text { Task a: Consult with Western's EMF } \\
\text { Committee and EPRI }\end{array}$ & Annually & Annually & Annually \\
\hline $\begin{array}{l}\text { 13. All requirements of those entities having } \\
\text { jurisdiction over air quality matters would be adhered } \\
\text { to and any permits needed for construction activities } \\
\text { would be obtained. Open burning of construction } \\
\text { trash would not be allowed unless permitted by } \\
\text { appropriate authorities. }\end{array}$ & $\begin{array}{l}\text { G5600 } \\
\text { G5600 } \\
\text { G0400/G5600 }\end{array}$ & $\begin{array}{l}\text { Task a: Incorporate requirement into } \\
\text { construction specification } \\
\text { Task b: Advise construction contractor } \\
\text { Task c: Monitor construction }\end{array}$ & $\begin{array}{l}\text { Complete } \\
\text { Complete } \\
12 / 99-09 / 00\end{array}$ & $\begin{array}{l}\text { Complete } \\
02 / 00 \\
03 / 00-09 / 00\end{array}$ & $\begin{array}{l}06 / 00 \\
10 / 00 \\
10 / 00-02 / 01\end{array}$ \\
\hline
\end{tabular}




\begin{tabular}{|c|c|c|c|c|c|}
\hline \multirow[b]{2}{*}{ Generic and/or Selective Mitigation Commitment } & \multirow[b]{2}{*}{$\begin{array}{c}\text { Responsible } \\
\text { Party }\end{array}$} & \multirow[b]{2}{*}{ Action } & \multicolumn{3}{|c|}{ Target Completion Date } \\
\hline & & & Peacock Sub & New TL's & $\begin{array}{l}\text { Davis-Peacock } \\
\text { Improvements }\end{array}$ \\
\hline $\begin{array}{l}\text { 14. Fences and gates would be repaired or replaced } \\
\text { to their original condition prior to Project disturbance } \\
\text { as required by the landowner or the land management } \\
\text { agency if they are damaged or destroyed by } \\
\text { construction activities. Temporary gates would be } \\
\text { installed only with the permission of the landowner } \\
\text { or the land managing agency. Note: Permanent } \\
\text { gates will be installed if needed for access for } \\
\text { maintenance needs. }\end{array}$ & $\begin{array}{l}\text { G5600 } \\
\text { G5600 } \\
\text { G0400/G5600 } \\
\text { G5600 }\end{array}$ & $\begin{array}{l}\text { Task a: Incorporate requirement into } \\
\text { construction specification } \\
\text { Task b: Advise construction contractor } \\
\text { Task c: Monitor site work } \\
\text { Task d: Post-Construction review }\end{array}$ & $\begin{array}{l}\text { Complete } \\
\text { Complete } \\
12 / 99-01 / 00 \\
09 / 00\end{array}$ & $\begin{array}{l}\text { Complete } \\
02 / 00 \\
03 / 00-09 / 00 \\
09 / 00\end{array}$ & $\begin{array}{l}06 / 00 \\
10 / 00 \\
10 / 00-02 / 01 \\
03 / 01\end{array}$ \\
\hline $\begin{array}{l}\text { 15. Transmission line materials would be designed } \\
\text { and tested to minimize corona. Tension would be } \\
\text { maintained on all insulator assemblies to assure } \\
\text { positive contact between insulators, thereby avoiding } \\
\text { sparking. Caution would be exercised during } \\
\text { construction to avoid scratching or nicking the } \\
\text { conductor surface, which may provide points for } \\
\text { corona to occur. }\end{array}$ & $\begin{array}{l}\mathrm{A} 3900 \\
\mathrm{G} 5600\end{array}$ & $\begin{array}{l}\text { Task a: Design to minimize corona } \\
\text { Task b: Monitor construction activities }\end{array}$ & $\begin{array}{l}\text { Not Applicable } \\
\text { Not Applicable }\end{array}$ & $\begin{array}{l}\text { Complete } \\
03 / 00-09 / 00\end{array}$ & $\begin{array}{l}02 / 00-04 / 00 \\
10 / 00-02 / 01\end{array}$ \\
\hline $\begin{array}{l}\text { 16. Nonspecular conductors, groundwires and dulled } \\
\text { structure components would be used to reduce visual } \\
\text { impacts. }\end{array}$ & $\mathrm{A} 3900$ & $\begin{array}{l}\text { Task a: Incorporate requirements into } \\
\text { construction specification }\end{array}$ & Not Applicable & Complete & $06 / 00$ \\
\hline $\begin{array}{l}\text { 17. No nonbiodegradable debris would be deposited } \\
\text { in the ROWs. Slash and other biodegradable debris } \\
\text { would be left in place or disposed of in accordance } \\
\text { with agency requirements. }\end{array}$ & $\begin{array}{l}\text { G5600 } \\
\text { G5600 } \\
\text { G0400/G5600 } \\
\text { G5600 }\end{array}$ & $\begin{array}{l}\text { Task a: Incorporate requirement into } \\
\text { construction specification } \\
\text { Task b: Advise construction contractor } \\
\text { Task c: Monitor site work } \\
\text { Task d: Post-Construction review }\end{array}$ & $\begin{array}{l}\text { Complete } \\
\text { Complete } \\
12 / 99-01 / 00 \\
09 / 00 \\
\end{array}$ & $\begin{array}{l}\text { Complete } \\
02 / 00 \\
03 / 00-09 / 00 \\
09 / 00\end{array}$ & $\begin{array}{l}06 / 00 \\
10 / 00 \\
10 / 00-02 / 01 \\
03 / 01\end{array}$ \\
\hline
\end{tabular}




\begin{tabular}{|c|c|c|c|c|c|}
\hline \multirow[b]{2}{*}{ Generic and/or Selective Mitigation Commitment } & \multirow[b]{2}{*}{$\begin{array}{l}\text { Responsible } \\
\text { Party }\end{array}$} & \multirow[b]{2}{*}{ Action } & \multicolumn{3}{|c|}{ Target Completion Date } \\
\hline & & & Peacock Sub & New TL's & $\begin{array}{l}\text { Davis-Peacock } \\
\text { Improvements }\end{array}$ \\
\hline $\begin{array}{l}\text { 18. If required, mitigation measures developed } \\
\text { during the consultation period under Section } 7 \text { of the } \\
\text { Endangered Species Act would be adhered to as } \\
\text { specified in the Biological Opinion of the U.S. DOI } \\
\text { Fish and Wildlife Service. Also, mitigation } \\
\text { developed in conjunction with state and tribal } \\
\text { authorities would be adhered to. }\end{array}$ & G0400/A3400 & $\begin{array}{l}\text { Task a: Survey for peregrine falcon nests per } \\
\text { conditions set by USFWS. }\end{array}$ & Complete & $04 / 00$ & $04 / 00$ \\
\hline $\begin{array}{l}\text { 19. Hazardous materials would not be drained onto } \\
\text { the ground or into streams or drainage areas. Totally } \\
\text { enclosed containment would be provided for all } \\
\text { trash. All construction waste including trash and } \\
\text { litter, garbage, other solid waste, petroleum products, } \\
\text { and other potentially hazardous materials would be } \\
\text { removed to a disposal facility authorized to accept } \\
\text { such materials. }\end{array}$ & $\begin{array}{l}\text { G5600 } \\
\text { G5600 } \\
\text { G0400/G5600 } \\
\text { G5600 }\end{array}$ & $\begin{array}{l}\text { Task a: Incorporate requirement into } \\
\text { construction specification } \\
\text { Task b: Advise construction contractor } \\
\text { Task c: Monitor site work } \\
\text { Task d: Post-Construction review }\end{array}$ & $\begin{array}{l}\text { Complete } \\
\text { Complete } \\
09 / 99-01 / 00 \\
09 / 00\end{array}$ & $\begin{array}{l}\text { Complete } \\
02 / 00 \\
03 / 00-09 / 00 \\
09 / 00\end{array}$ & $\begin{array}{l}06 / 00 \\
10 / 00 \\
10 / 00-02 / 01 \\
03 / 01\end{array}$ \\
\hline $\begin{array}{l}\text { 20. Near residences, the ROW would be aligned, to } \\
\text { the extent practicable, to reduce impact on the } \\
\text { residences and inhabitants. }\end{array}$ & $\begin{array}{l}\text { G5600 } \\
\text { G5600 }\end{array}$ & $\begin{array}{l}\text { Task a: Determine if residences are impacted } \\
\text { by ROW } \\
\text { Task b: Adjust alignment, if needed }\end{array}$ & Not applicable & $\begin{array}{l}12 / 99 \\
12 / 99\end{array}$ & $\begin{array}{l}02 / 00 \\
04 / 99\end{array}$ \\
\hline $\begin{array}{l}\text { 21. Special status species or other species of } \\
\text { particular concern would continue to be considered } \\
\text { during post-EIS phases of Project implementation in } \\
\text { accordance with management policies set forth by the } \\
\text { appropriate land managing agency. This may entail } \\
\text { conducting surveys for plant and wildlife species of } \\
\text { concern along the proposed transmission line route } \\
\text { and associated facilities (i.e., access and spur roads, } \\
\text { staging areas) as agreed upon by the land managing } \\
\text { agency and lead Federal agency. In cases where such } \\
\text { species are identified, appropriate action would be } \\
\text { taken to avoid adverse impacts on the species and its } \\
\text { habitat and may include altering the placement of } \\
\text { roads or towers as practicable and monitoring }\end{array}$ & $\begin{array}{l}\text { G0400 } \\
\text { G5600 } \\
\text { G5600 } \\
\text { G0400/G5600 }\end{array}$ & $\begin{array}{l}\text { Task a: Determine if special status species } \\
\text { are present } \\
\text { Task b: Coordinate design with affected } \\
\text { agencies and/or landowners. } \\
\text { Task c: Adjust tower placement, if needed } \\
\text { Task d: Monitor construction }\end{array}$ & $\begin{array}{l}\text { Complete } \\
\text { Not applicable } \\
\text { Not applicable } \\
\text { Not applicable }\end{array}$ & $\begin{array}{l}02 / 00-03 / 00 \\
12 / 99 \\
10 / 99--11 / 99 \\
03 / 00-09 / 00\end{array}$ & $\begin{array}{l}04 / 00 \\
04 / 00 \\
04 / 00 \\
10 / 00-02 / 01\end{array}$ \\
\hline
\end{tabular}




\begin{tabular}{|c|c|c|c|c|c|}
\hline & & & \multicolumn{3}{|c|}{ Target Completion Date } \\
\hline Generic and/or Selective Mitigation Commitment & $\begin{array}{c}\text { Responsible } \\
\text { Party }\end{array}$ & Action & Peacock Sub & New TL's & $\begin{array}{l}\text { Davis-Peacock } \\
\text { Improvements }\end{array}$ \\
\hline $\begin{array}{l}\text { construction activities. Surface disturbing activities } \\
\text { would be limited on the habitat for sensitive status } \\
\text { plant species. }\end{array}$ & & & & & \\
\hline $\begin{array}{l}\text { 22. The alignment of any new access roads would } \\
\text { follow the designated area's landform contours where } \\
\text { possible, providing that such alignment does not } \\
\text { additionally impact resource values. This would } \\
\text { minimize ground disturbance and reduce scarring } \\
\text { (visual contrast). }\end{array}$ & G5600 & $\begin{array}{l}\text { Task a: Determine new access road needs } \\
\text { Task b: Coordinate new access road } \\
\text { requirements with affected agencies and/or } \\
\text { landowners } \\
\text { Task c: Construct new roads consistent with } \\
\text { agency/landowner requirements }\end{array}$ & $\begin{array}{l}\text { No new access } \\
\text { roads required }\end{array}$ & $\begin{array}{l}08 / 99-02 / 00 \\
08 / 99-02 / 00 \\
03 / 00-05 / 00\end{array}$ & $\begin{array}{l}02 / 00-04 / 00 \\
04 / 00 \\
10 / 00-11 / 00\end{array}$ \\
\hline
\end{tabular}




\section{TABLE 4.2: SPECIFIC MITIGATION COMMITMENTS AND ACTION PLAN}

\begin{tabular}{|c|c|c|c|c|c|}
\hline & & & & \multicolumn{2}{|c|}{ Target Completion Date } \\
\hline Commitment by EIS Section & $\begin{array}{l}\text { Responsible } \\
\text { Party }\end{array}$ & Action & Peacock Sub & New TL's & $\begin{array}{c}\text { Davis-Peacock } \\
\text { Upgrade }\end{array}$ \\
\hline $\begin{array}{l}\text { Sec. 4.1.2.2: Structures would be designed for a } \\
\text { moderate seismic zone }\end{array}$ & A3900 & $\begin{array}{l}\text { Task a: Design substation } \\
\text { foundations for moderate seismic } \\
\text { zone }\end{array}$ & Complete & Complete & $02 / 00-04 / 00$ \\
\hline $\begin{array}{l}\text { Sec. 4.2.2.2: Spills would be contained, collected, } \\
\text { and shipped to an appropriate waste disposal facility. }\end{array}$ & $\begin{array}{l}\mathrm{G} 0400 \\
\mathrm{G} 0400\end{array}$ & $\begin{array}{l}\text { Task a: Evaluate need for spill, } \\
\text { prevention, control and } \\
\text { countermeasure plan, per } 40 \\
\text { CFR 112. } \\
\text { Task b: Develop plan, if needed. } \\
\text { Task c: Incorporate spill } \\
\text { containment requirements into } \\
\text { construction specification }\end{array}$ & $\begin{array}{l}\text { July } 00 \\
\text { Aug } 00 \\
\text { Complete }\end{array}$ & $\begin{array}{l}\text { N/A } \\
\text { N/A } \\
09 / 99-10 / 99\end{array}$ & $\begin{array}{l}\text { N/A } \\
\text { N/A } \\
06 / 00\end{array}$ \\
\hline $\begin{array}{l}\text { Sec. 4.5.2: Avoidance of riparian areas (other } \\
\text { vegetation mitigation addressed under generic and } \\
\text { selectively mitigation commitments). }\end{array}$ & G0400/G5600 & $\begin{array}{l}\text { Task a: Review structure and } \\
\text { access road locations to ensure } \\
\text { riparian areas are not impacted } \\
\text { Task b: Adjust locations, if } \\
\text { needed. }\end{array}$ & Not applicable & $\begin{array}{l}08 / 99-02 / 00 \\
02 / 00-04 / 99 \\
\end{array}$ & $\begin{array}{l}02 / 00-04 / 00 \\
04 / 00 \\
\end{array}$ \\
\hline $\begin{array}{l}\text { Sec. 4.5.2: Reseeding and plant salvaging per a BLM } \\
\text { approved Reclamation Operation Maintenance Plan. } \\
\text { Use third-party monitor in areas identified by BLM }\end{array}$ & $\begin{array}{l}\text { G0400/G5600 } \\
\text { G5600 } \\
\text { G5600 } \\
\text { G5600 }\end{array}$ & $\begin{array}{l}\text { Task a: Develop ROMP in } \\
\text { consultation with BLM. } \\
\text { Task b: Incorporate } \\
\text { requirements into construction } \\
\text { specification } \\
\text { Task c: Contract with third party } \\
\text { monitor } \\
\text { Task d: Monitor construction, } \\
\text { salvaging, replanting and }\end{array}$ & Not applicable & $\begin{array}{l}09 / 99-12 / 99 \\
12 / 99 \\
01 / 00 \\
03 / 00-09 / 00\end{array}$ & N/A \\
\hline
\end{tabular}




\begin{tabular}{|c|c|c|c|c|c|}
\hline \multirow[b]{2}{*}{ Commitment by EIS Section } & \multirow[b]{2}{*}{$\begin{array}{l}\text { Responsible } \\
\text { Party }\end{array}$} & \multirow[b]{2}{*}{ Action } & \multirow[b]{2}{*}{ Peacock Sub } & \multicolumn{2}{|c|}{ Target Completion Date } \\
\hline & & & & New TL's & $\begin{array}{c}\text { Davis-Peacock } \\
\text { Upgrade }\end{array}$ \\
\hline & & reseeding & & & \\
\hline Sec. 4.6.2.2: Preconstruction surveys for raptor nests. & G0400/A3400 & Task a: Conduct aerial surveys & $\begin{array}{l}\text { Complete, None } \\
\text { identified }\end{array}$ & $04 / 00$ & $04 / 00$ \\
\hline $\begin{array}{l}\text { Sec. 4.6.2.2: A desert tortoise mitigation plan (Item } \\
10 \text { of Table } 2.1-4 \text { in the Final EIS) will be } \\
\text { implemented, which will include preconstruction } \\
\text { surveys and compensation for unmitigated impacts. } \\
\text { The }\end{array}$ & $\begin{array}{l}\text { G0400/G5600 } \\
\text { G5600 } \\
\text { G5600 } \\
\text { G0400 } \\
\text { G0400/G5600 }\end{array}$ & $\begin{array}{l}\text { Task a: Coordinate requirements } \\
\text { with BLM } \\
\text { Task b: Incorporate applicable } \\
\text { requirements into the } \\
\text { construction specification } \\
\text { Task c: Contract with biological } \\
\text { montior } \\
\text { Task d: Preconstruction desert } \\
\text { tortoise survey by a qualified } \\
\text { biologist } \\
\text { Task e: Educate construction } \\
\text { workers }\end{array}$ & Not Applicable & $\begin{array}{l}\text { Complete } \\
\text { Complete } \\
01 / 99 \\
03 / 00 \\
02 / 00\end{array}$ & $\begin{array}{l}02 / 00-04 / 00 \\
06 / 00 \\
09 / 00 \\
09 / 00 \\
10 / 00\end{array}$ \\
\hline $\begin{array}{l}\text { Sec. 4.6.2.2: ROW construction, restoration, } \\
\text { maintenance and termination activities in designated } \\
\text { areas would be modified or discontinued during } \\
\text { sensitive periods for candidate, proposed, threatened } \\
\text { and endangered, or other sensitive animal species } \\
\text { (per selective mitigation in Table } 2.1-4 \text { ). Avoidance } \\
\text { of construction during breeding of mountain plovers, } \\
\text { if present }\end{array}$ & G0400/G5600 & $\begin{array}{l}\text { Task a: Incorporate } \\
\text { requirements into construction } \\
\text { specification }\end{array}$ & None identified & None identified & $\begin{array}{l}\text { Mountain plover } \\
\text { not present per } \\
\text { consultation with } \\
\text { BLM }\end{array}$ \\
\hline $\begin{array}{l}\text { Sec. 4.7.2.2: Hualapai tribal participation in the } \\
\text { intensive cultural resource surveys for the new } \\
\text { transmission lines and the upgrade of the existing } \\
\text { Davis-Prescott line. }\end{array}$ & G0400/G5600 & $\begin{array}{l}\text { Task a: Ensure applicant } \\
\text { contracts with the Hualapai }\end{array}$ & Complete & Complete & Complete \\
\hline
\end{tabular}




\begin{tabular}{|c|c|c|c|c|c|}
\hline & & & & Target $C$ & pletion Date \\
\hline Commitment by EIS Section & $\begin{array}{c}\text { Responsible } \\
\text { Party }\end{array}$ & Action & Peacock Sub & New TL's & $\begin{array}{c}\text { Davis-Peacock } \\
\text { Upgrade }\end{array}$ \\
\hline $\begin{array}{l}\text { Sec. 4.7.2.2: In locations identified during cultural } \\
\text { resource inventory as having the potential to contain } \\
\text { sensitive cultural resources to the Hualapai Tribe, } \\
\text { Hualapai representatives will be invited to monitor } \\
\text { right-of-way blading and construction. }\end{array}$ & G0400/A3400 & $\begin{array}{l}\text { Task a: Consult with Hualapai } \\
\text { on results of intensive cultural } \\
\text { resource survey } \\
\text { Task b: If needed, modify } \\
\text { structure and access road } \\
\text { locations, if possible, and/or } \\
\text { explore mitigation }\end{array}$ & Complete & $\begin{array}{l}01 / 00 \\
01 / 00\end{array}$ & $\begin{array}{l}10 / 99 \\
04 / 00\end{array}$ \\
\hline $\begin{array}{l}\text { Sec. 4.8.2.2: Coordination with interested property } \\
\text { owners on structure siting to reduce land use and } \\
\text { visual impacts. }\end{array}$ & $\begin{array}{l}\text { Lands } \\
\text { G5600 } \\
\text { G5600/A3900 }\end{array}$ & $\begin{array}{l}\text { Task a: Determine land owner } \\
\text { interest during land acquisition } \\
\text { phase of project } \\
\text { Task b: Share structure } \\
\text { locations with interested land } \\
\text { owners } \\
\text { Task c: Adjust structure } \\
\text { locations, if needed. }\end{array}$ & Not applicable & $\begin{array}{l}09 / 99-01 / 00 \\
01 / 00 \\
01 / 00\end{array}$ & $\begin{array}{l}\text { N/A } \\
02 / 00-04 / 00 \\
04 / 00\end{array}$ \\
\hline
\end{tabular}


TABLE 4.3: ACTION Plan FOR WESTERN'S Mitigation COMMITMENTS FOR THE GRIFFITH POWER PLANT

\begin{tabular}{|c|c|c|c|}
\hline Commitment per ROD & $\begin{array}{c}\text { Responsible } \\
\text { Party }\end{array}$ & Action & $\begin{array}{c}\text { Target } \\
\text { Completion } \\
\text { Date }\end{array}$ \\
\hline $\begin{array}{l}\text { 1. Western's review and approval of dust } \\
\text { control procedures for the construction of the } \\
\text { Griffith Power Plant as required by the ADEQ } \\
\text { air permit. }\end{array}$ & G0400 & $\begin{array}{l}\text { Task a: Review dust control provisions } \\
\text { stipulated in ADEQ permit. } \\
\text { Task b: Approve or suggest modifications to } \\
\text { dust control provisions. }\end{array}$ & $\begin{array}{l}\text { Complete } \\
\text { Complete }\end{array}$ \\
\hline $\begin{array}{l}\text { 2. Power plant lighting compliance with } \\
\text { Mohave County illumination ordinances and us } \\
\text { of partially-or fully-shielded fixtures during } \\
\text { darkness. }\end{array}$ & G0400 & $\begin{array}{l}\text { Task a: Consult with Griffith Energy on } \\
\text { design of plant lighting. } \\
\text { Task b: Compare design parameters with } \\
\text { applicable Mohave County ordinances. } \\
\text { Task c: Consult with Griffith on any } \\
\text { differences }\end{array}$ & $\begin{array}{l}\text { March } 00 \\
\text { April } 00 \\
\text { May } 00\end{array}$ \\
\hline $\begin{array}{l}\text { 3. Painting plant with colors similar to the } \\
\text { surrounding landscape }\end{array}$ & G0400 & $\begin{array}{l}\text { Task a: Consult with Griffith Energy on } \\
\text { design of plant coloring. } \\
\text { Task b: Compare design parameters with EIS } \\
\text { commitments. } \\
\text { Task c: Consult with Griffith on any } \\
\text { differences }\end{array}$ & $\begin{array}{l}\text { March } 00 \\
\text { April } 00 \\
\text { May } 00\end{array}$ \\
\hline $\begin{array}{l}\text { 4. Monitoring and reporting of waterfowl use } \\
\text { and impacts at the brine disposal pond. }\end{array}$ & G0400 & $\begin{array}{l}\text { Task a: Define monitroing and reporting } \\
\text { requirements. } \\
\text { Task b: Incorporate monitoring and reporting } \\
\text { requirements into interconnection agreement. } \\
\text { Task c: Review monitoring reports. } \\
\text { Task d: Consult with Arizona Game and Fish } \\
\text { Department on monitoring results. } \\
\text { Task e: If problem is encountered, explore } \\
\text { additional mitigation with Griffith and } \\
\text { AGFD. }\end{array}$ & $\begin{array}{l}\text { Complete } \\
\text { Complete } \\
\text { Quarterly } \\
\text { Annually }\end{array}$ \\
\hline
\end{tabular}


A.PPENDIX E

REPORT ON THE

MITIGATION ACTION PLAN

FOR THE

SOUTHPOINT POWER PLANT 


\section{MITIGATION ACTION PLAN \\ FOR THE \\ SOUTHPOINT POWER PLANT PROJECT}

\section{INTRODUCTION}

The Southpoint Power Plant Project (Southpoint) Environmental Impact Statement (EIS) was prepared by the Bureau of Indian Affairs (BIA) (DES 98-25) and adopted by the Western Area Power Administration (Western). Western's action in Southpoint includes granting an interconnection to the Parker-Davis Project; constructing, operating and maintaining two 230kilovolt $(\mathrm{kV})$ transmission lines and one $69-\mathrm{kV}$ transmission line; and reconductoring the ParkerDavis No.1 230-kV transmission line. The latter action will also require the addition of five new structures within the longest spans of the existing right-of-way to increase ground clearance.

Western found that additional information was required to comply with the Department of Energy regulations for implementing the National Environmental Policy Act. The EIS did not discuss the need to reconductor the Parker-Davis No.1. For this reason, Western prepared a Supplement Analysis (DOE/EIS-0308-SA-1) and determined a Supplemental EIS would not be needed. The mitigation measures discussed in that Supplement Analysis are included in this Mitigation Action Plan as Table 2.

The transmission lines, which will connect the Southpoint Power Plant to the Parker-Davis Project and be operated and maintained by Western, are described in Western's second Supplement Analysis (DOE/EIS-0308-SA-2). The second Supplement Analysis was prepared to address changing the new transmission lines from a single, triple-circuit line to one single- and one double-circuit line. The mitigation measures discussed in that document are found in Table 3 , and will be implemented and tracked by Western.

The mitigation measures described in the EIS are listed in this document with the understanding that their implementation will be the responsibility of the Calpine Corporation and the Fort Mojave Indian.Tribe. Mitigation for the construction and operation of the power plant is shown in Table 1. The Fort Mojave Indian Tribe and the BIA will be responsible for implementing these measures. 
Mitigation for the gas pipeline is described in the Environmental Assessment prepared by the U.S. Bureau of Land Management (BLM), Lake Havasu Field Office. Only two mitigation measures were identified as necessary in the EA. Mitigation for the construction and operation of the gas pipeline is shown in Table 1. The BLM will ensure implementation of the mitigation described in its document.

Table 1. Mitigation for impacts of the construction and operation of the Southpoint Power Plant and gas pipeline.

\begin{tabular}{|c|c|c|c|}
\hline & Mitigation Measure & $\begin{array}{l}\text { Responsible } \\
\text { Party }\end{array}$ & Action \\
\hline • & $\begin{array}{l}\text { Minimize impacts to the Sonoran desert } \\
\text { tortoise and its habitat during construction } \\
\text { of the power plant and the gas pipeline. }\end{array}$ & Calpine & $\begin{array}{l}\text { Conduct surveys for the tortoise and provide } \\
\text { compensation for loss of habitat. }\end{array}$ \\
\hline$\bullet$ & $\begin{array}{l}\text { Provide Fire Protection and Emergency } \\
\text { Medical Response to the site. }\end{array}$ & FMIT & $\begin{array}{l}\text { Modify the existing contract with the } \\
\text { Mojave Valley Fire Department to include } \\
\text { the proposed power plant location. }\end{array}$ \\
\hline & \multirow[t]{2}{*}{$\begin{array}{l}\text { Develop and implement an Emergency } \\
\text { HazMat Response Action Plan. }\end{array}$} & FMIT & $\begin{array}{l}\text { Form a Tribal Emergency Response } \\
\text { Committee which will meet USEPA } \\
\text { guidelines. }\end{array}$ \\
\hline & & FMIT & $\begin{array}{l}\text { Enter into a contract with the Bullhead City } \\
\text { Fire Department or other entity for response } \\
\text { services. }\end{array}$ \\
\hline & $\begin{array}{l}\text { Minimize traffic and transportation impacts } \\
\text { during construction at the intersection of } \\
\text { County Road } 227 \text { and State Route } 95 \text {. }\end{array}$ & $\begin{array}{l}\text { Calpine } \\
\text { Calpine }\end{array}$ & $\begin{array}{l}\text { Place flaggers at appropriate locations. } \\
\text { Schedule deliveries at off-peak times. }\end{array}$ \\
\hline & \multirow[t]{6}{*}{$\begin{array}{l}\text { Minimize impacts to migratory birds from } \\
\text { the evaporation ponds. }\end{array}$} & $\begin{array}{l}\text { Calpine } \\
\text { Calpine }\end{array}$ & $\begin{array}{l}\text { Locate ponds on bluffs, above the valley } \\
\text { flyway. } \\
\text { Design ponds with steep side slopes to make } \\
\text { them less attractive to migratory birds. }\end{array}$ \\
\hline & & FMIT & $\begin{array}{l}\text { Place bird-of-prey decoys mounted on poles } \\
\text { around the ponds and rotate them weekly. }\end{array}$ \\
\hline & & Calpine/FMIT & Place flagging around and/or across ponds. \\
\hline & & FMIT & $\begin{array}{l}\text { Conduct quarterly monitoring of species } \\
\text { visiting the ponds. }\end{array}$ \\
\hline & & Calpine & $\begin{array}{l}\text { Conduct quarterly monitoring of hazardous } \\
\text { substances in pond water and sediments. }\end{array}$ \\
\hline & & Calpine/FMIT & $\begin{array}{l}\text { Provide netting to exclude waterfowl, if } \\
\text { warranted. }\end{array}$ \\
\hline & $\begin{array}{l}\text { Minimize visual impacts to residents and } \\
\text { travelers along the road between Needles } \\
\text { and Golden Shores. }\end{array}$ & Calpine & Paint the plant with harmonizing colors. \\
\hline & $\begin{array}{l}\text { Minimize soil erosion during construction } \\
\text { of the gas pipeline. }\end{array}$ & Calpine & $\begin{array}{l}\text { Install trench plugs to keep water from } \\
\text { moving along the pipe and water bars to } \\
\text { direct water away from the trench. }\end{array}$ \\
\hline
\end{tabular}




\section{Western's Mitigation Measures and Action Plan}

Certain mitigation measures will be implemented for all phases of Western's involvement in the Southpoint Power Plant Project. These istclude the salvage and/or relocation of plants protected by the Arizona Native Plant law. This law protects many of the cacti, yucca and other plants native to Arizona that are not formally protected by other Federal or State regulations. Western will ensure that the Topock-Parker No.1 and Southpoint-Topock rights-of-way are surveyed for plants of concern and mark them for avoidance or relocate them out of harm's way, unless other requests are made by the landowner or land managing agency.

Raptor nesting surveys will be undertaken along the existing Parker-Davis lines prior to the start of the reconductoring activities. The survey will locate active nests of birds of prey.

The Project's Standard Construction Practices, which have been adopted by Western for the proposed transmission additions, are presented in Table 2.

Table 2. Action Plan for Applicable Generic Mitigation Measures, Southpoint-Topock 230-kV and 69-kV Transmission lines.

\begin{tabular}{|c|c|c|c|}
\hline $\begin{array}{l}\text { Generic and/or Selective } \\
\text { Mitigation Commitment }\end{array}$ & $\begin{array}{l}\text { Responsible } \\
\text { Party }\end{array}$ & Action & $\begin{array}{c}\text { Target } \\
\text { Completion } \\
\text { Date }\end{array}$ \\
\hline $\begin{array}{l}\text { 1. All construction vehicle movement } \\
\text { outside the ROW normally would be } \\
\text { restricted to predesignated access, } \\
\text { contractor acquired access, or public } \\
\text { roads. No widening or upgrading of } \\
\text { existing access roads would be undertaken } \\
\text { in the area of construction and operation, } \\
\text { except for repairs necessary to make roads } \\
\text { passable, where soils or vegetation are } \\
\text { very sensitive to disturbance. }\end{array}$ & $\begin{array}{l}\text { G5600 } \\
\text { G5600 } \\
\text { G5600/G0400 }\end{array}$ & $\begin{array}{l}\text { Task a: Incorporate } \\
\text { requirement into construction } \\
\text { specification. } \\
\text { Task b: Advise construction } \\
\text { contractor. } \\
\text { Task c: Monitor site work. }\end{array}$ & $\begin{array}{l}\text { Completed } \\
10 / 99 \\
01 / 31 / 00 \\
09 / 01 / 00\end{array}$ \\
\hline $\begin{array}{l}\text { 2. The limits of construction activities } \\
\text { normally would be predetermined, with } \\
\text { activity restricted to and confined within } \\
\text { those limits. No paint or permanent } \\
\text { discoloring agents would be applied to } \\
\text { rocks or vegetation to indicate limits of } \\
\text { survey or construction activity. There will } \\
\text { be no blading of new access roads unless } \\
\text { approved by Western and the land } \\
\text { management agency. }\end{array}$ & $\begin{array}{l}\text { G5600 } \\
\text { G5600 } \\
\text { G5600/G0400 }\end{array}$ & $\begin{array}{l}\text { Task a: Incorporate } \\
\text { requirement into construction } \\
\text { specification. } \\
\text { Task b: Advise construction } \\
\text { contractor. } \\
\text { Task c: Monitor site work. }\end{array}$ & $\begin{array}{l}\text { Completed } \\
10 / 99 \\
01 / 31 / 00 \\
09 / 01 / 00\end{array}$ \\
\hline $\begin{array}{l}\text { 3. In construction areas where } \\
\text { recontouring is not required, vegetation } \\
\text { would be left in place wherever possible } \\
\text { and original contour would be maintained } \\
\text { to avoid excessive root damage and allow } \\
\text { for resprouting. }\end{array}$ & $\begin{array}{l}\text { G5600 } \\
\text { G5600 } \\
\text { G5600/G0400 }\end{array}$ & $\begin{array}{l}\text { Task a: Incorporate } \\
\text { requirement into construction } \\
\text { specification. } \\
\text { Task b: Advise construction } \\
\text { contractor. } \\
\text { Task c: Monitor site work. }\end{array}$ & $\begin{array}{l}\text { Completed } \\
10 / 99 \\
01 / 31 / 00 \\
09 / 01 / 00\end{array}$ \\
\hline
\end{tabular}




\begin{tabular}{|c|c|c|c|}
\hline $\begin{array}{l}\text { Generic and/or Selective } \\
\text { Mitigation Commitment }\end{array}$ & $\begin{array}{l}\text { Responsible } \\
\text { Party }\end{array}$ & Action & $\begin{array}{c}\text { Target } \\
\text { Completion } \\
\text { Date } \\
\end{array}$ \\
\hline $\begin{array}{l}\text { 4. In construction areas (e.g., marshaling } \\
\text { yards, tower sites, spur roads from } \\
\text { existing access roads) where ground } \\
\text { disturbance is substantial or where } \\
\text { recontouring is required, surface } \\
\text { restoration would occur as required by the } \\
\text { landowner or land management agency. } \\
\text { The method of restoration normally would } \\
\text { consist of returning disturbed areas back } \\
\text { to their natural contour, reseeding (if } \\
\text { required), installing cross drains for } \\
\text { erosion control, placing water bars in the } \\
\text { road, and filling ditches. To avoid } \\
\text { fragmentation of desert bighorn habitat, } \\
\text { fencing would not be used to close roads } \\
\text { or otherwise limit access. Any new access } \\
\text { roads not required for maintenance would } \\
\text { be permanently closed using the most } \\
\text { effective and least environmentally } \\
\text { damaging methods appropriate to that area } \\
\text { with concurrence of the landowner or land } \\
\text { manager. These instances would be } \\
\text { reviewed on a case-by-case basis. }\end{array}$ & G0400/G5600 & $\begin{array}{l}\text { Task a: Prepare construction } \\
\text { operation and maintenance } \\
\text { plan. } \\
\text { Task b: Coordinate } \\
\text { restoration activities with } \\
\text { BLM. } \\
\text { Task c: Determine landowner } \\
\text { restoration needs. } \\
\text { Task d: Incorporate } \\
\text { requirements into construction } \\
\text { contract. } \\
\text { Task e: Monitoring. }\end{array}$ & $\begin{array}{l}\text { Completed } \\
10 / 99 \\
10 / 31 / 00\end{array}$ \\
\hline $\begin{array}{l}\text { 5. Watering facilities and other range } \\
\text { improvements would be repaired or } \\
\text { replaced if they are damaged or destroyed } \\
\text { by construction activities to their } \\
\text { condition prior to disturbance as agreed to } \\
\text { by the parties involved. }\end{array}$ & G5600 & $\begin{array}{l}\text { Task a: Post-Construction } \\
\text { Review. }\end{array}$ & None planned \\
\hline $\begin{array}{l}\text { 6. Towers and/or ground wire would be } \\
\text { marked with highly visible devices where } \\
\text { required by governmental agencies (e.g., } \\
\text { Federal Aviation Administration) for } \\
\text { aircraft safety. }\end{array}$ & $\begin{array}{l}\mathrm{A} 3900 \\
\mathrm{G} 5600\end{array}$ & $\begin{array}{l}\text { Task a: Determine need for } \\
\text { marking. } \\
\text { Task b: Install markers, if } \\
\text { required. }\end{array}$ & $\begin{array}{l}\text { None planned } \\
\text { N/A }\end{array}$ \\
\hline $\begin{array}{l}\text { 7. Prior to construction, all supervisory } \\
\text { construction personnel would be } \\
\text { instructed on measures to protect cultural, } \\
\text { paleontological, and ecological resources. }\end{array}$ & G5600/G0400 & $\begin{array}{l}\text { Task a: Advise construction } \\
\text { contractor at pre-construction } \\
\text { conference. }\end{array}$ & $01 / 31 / 00$ \\
\hline $\begin{array}{l}\text { 8. Cultural resources would continue to } \\
\text { be considered during post-EIS phases of } \\
\text { Project implementation in accordance } \\
\text { with the programmatic agreement that is } \\
\text { being developed in conjunction with } \\
\text { preparation of the EIS. }\end{array}$ & $\begin{array}{l}\text { G0400/A3400 } \\
\text { G0400/A3400 } \\
\text { G0400/A3400 } \\
\text { G0400/A3400 } \\
\text { G0400/A3400 } \\
\text { G0400/G5600 }\end{array}$ & $\begin{array}{l}\text { Task a: Conduct intensive } \\
\text { survey. } \\
\text { Task b: Conduct } \\
\text { ethnographic study. } \\
\text { Task c: Consult with tribes. } \\
\text { Task d: Consult with SHPO. } \\
\text { Task e: Determine project } \\
\text { modifications. } \\
\text { Task f: Construction } \\
\text { monitoring. }\end{array}$ & $\begin{array}{l}\text { Completed } \\
10 / 99 \\
\text { Completed } \\
10 / 99 \\
\text { Completed } \\
10 / 99 \\
\text { Complete } \\
\text { Complete } \\
\\
10 / 31 / 00\end{array}$ \\
\hline
\end{tabular}




\begin{tabular}{|c|c|c|c|}
\hline $\begin{array}{l}\text { Generic and/or Selective } \\
\text { Mitigation Commitment }\end{array}$ & $\begin{array}{l}\text { Responsible } \\
\text { Party }\end{array}$ & Action & $\begin{array}{c}\text { Target } \\
\text { Completion } \\
\text { Date }\end{array}$ \\
\hline $\begin{array}{l}\text { 9. Western would respond to individual } \\
\text { complaints of radio or television } \\
\text { interference generated by the transmission } \\
\text { line by investigating the complaints and } \\
\text { implementing appropriate mitigation } \\
\text { measures (e.g., adjusting or using filtering } \\
\text { devices on antennae). The transmission } \\
\text { line would be patrolled on a regular basis } \\
\text { so that damaged insulators or other } \\
\text { transmission line materials, which could } \\
\text { cause interference, are repaired or } \\
\text { replaced. }\end{array}$ & $\begin{array}{l}\text { G5000 } \\
\text { G5000 }\end{array}$ & $\begin{array}{l}\text { Task a: Respond to } \\
\text { complaints. } \\
\text { Task b: Transmission line } \\
\text { Patrols. } \\
\text { Task c: Replace damaged } \\
\text { insulators or conductor. }\end{array}$ & $\begin{array}{l}\text { Ongoing } \\
\text { Ongoing } \\
\text { Semi-annual } \\
\text { As needed }\end{array}$ \\
\hline $\begin{array}{l}\text { 10. Western would apply mitigation } \\
\text { needed to eliminate problems of induced } \\
\text { currents and voltages onto conductive } \\
\text { objects sharing a ROW to the mutual } \\
\text { satisfaction of the parties involved. }\end{array}$ & G5000 & $\begin{array}{l}\text { Task a: Respond to } \\
\text { complaints. }\end{array}$ & Ongoing \\
\hline $\begin{array}{l}\text { 11. Western would continue to monitor } \\
\text { studies performed to determine the effects } \\
\text { of audible noise and electrostatic and } \\
\text { electric magnetic fields to ascertain } \\
\text { whether these effects are significant. }\end{array}$ & G0400 & $\begin{array}{l}\text { Task a: Consult with } \\
\text { Western's EMF Committee } \\
\text { and EPRI. }\end{array}$ & $\begin{array}{l}\text { Ongoing } \\
\text { Annual }\end{array}$ \\
\hline $\begin{array}{l}\text { 12. Roads would be built at right angles } \\
\text { to the streams and washes to the extent } \\
\text { practicable. Culverts would be installed } \\
\text { where needed. All construction and } \\
\text { maintenance activities would be } \\
\text { conducted in a manner that would } \\
\text { minimize disturbance to vegetation, } \\
\text { drainage channels, and intermittent or } \\
\text { perennial streambanks. In addition, road } \\
\text { construction would include dust-control } \\
\text { measures during construction in sensitive } \\
\text { areas. All existing roads would be left in } \\
\text { a condition equal to or better than their } \\
\text { condition prior to the construction of the } \\
\text { transmission line. }\end{array}$ & $\begin{array}{l}\text { G5600 } \\
\text { G5600 } \\
\text { G0400/G5600 }\end{array}$ & $\begin{array}{l}\text { Task a: Incorporate } \\
\text { requirement into construction } \\
\text { specification. } \\
\text { Task b: Advise construction } \\
\text { contractor. } \\
\text { Task c: Monitor site work. }\end{array}$ & $\begin{array}{l}\text { Completed } \\
10 / 99 \\
01 / 31 / 00 \\
09 / 30 / 00\end{array}$ \\
\hline $\begin{array}{l}\text { 13. All requirements of those entities } \\
\text { having jurisdiction over air quality matters } \\
\text { would be adhered to and any permits } \\
\text { needed for construction activities would } \\
\text { be obtained. Open burning of } \\
\text { construction trash would not be allowed } \\
\text { unless permitted by appropriate } \\
\text { authorities. }\end{array}$ & $\begin{array}{l}\text { G5600 } \\
\text { G5600 } \\
\text { G0400/G5600 }\end{array}$ & $\begin{array}{l}\text { Task a: Incorporate } \\
\text { requirement into construction } \\
\text { specification. } \\
\text { Task b: Advise construction } \\
\text { contractor. } \\
\text { Task c: Monitor construction. }\end{array}$ & $\begin{array}{l}\text { Completed } \\
10 / 99 \\
01 / 31 / 00 \\
09 / 30 / 00\end{array}$ \\
\hline
\end{tabular}




\begin{tabular}{|c|c|c|c|}
\hline $\begin{array}{l}\text { Generic and/or Selective } \\
\text { Mitigation Commitment }\end{array}$ & $\begin{array}{l}\text { Responsible } \\
\text { Party }\end{array}$ & Action & $\begin{array}{c}\text { Target } \\
\text { Completion } \\
\text { Date } \\
\end{array}$ \\
\hline $\begin{array}{l}\text { 14. Fences and gates would be repaired } \\
\text { or replaced to their original condition } \\
\text { prior to Project disturbance as required by } \\
\text { the landowner or the land management } \\
\text { agency if they are damaged or destroyed } \\
\text { by construction activities. Temporary } \\
\text { gates would be installed only with the } \\
\text { permission of the landowner or the land- } \\
\text { managing agency. }\end{array}$ & $\begin{array}{l}\text { G5600 } \\
\text { G5600 } \\
\text { G0400/G5600 } \\
\text { G5600 }\end{array}$ & $\begin{array}{l}\text { Task a: Incorporate } \\
\text { requirement into construction } \\
\text { specification. } \\
\text { Task b: Advise construction } \\
\text { contractor. } \\
\text { Task c: Monitor site work. } \\
\text { Task d: Post-Construction } \\
\text { review. }\end{array}$ & $\begin{array}{l}\text { Completed } \\
10 / 99 \\
01 / 31 / 00 \\
10 / 31 / 00 \\
10 / 31 / 00\end{array}$ \\
\hline $\begin{array}{l}\text { 15. Transmission line materials would be } \\
\text { designed and tested to minimize corona. } \\
\text { Tension would be maintained on all } \\
\text { insulator assemblies to assure positive } \\
\text { contact between insulators, thereby } \\
\text { avoiding sparking. Caution would be } \\
\text { exercised during construction to avoid } \\
\text { scratching or nicking the conductor } \\
\text { surface, which may provide points for } \\
\text { corona to occur. }\end{array}$ & G5600 & $\begin{array}{l}\text { Task a: Design to minimize } \\
\text { corona. } \\
\text { Task b: Monitor construction } \\
\text { activities. }\end{array}$ & $10 / 31 / 00$ \\
\hline $\begin{array}{l}\text { 16. Nonspecular conductors, groundwires } \\
\text { and dulled structure components would be } \\
\text { used to reduce visual impacts. }\end{array}$ & A3900 & $\begin{array}{l}\text { Task a: Incorporate } \\
\text { requirements into construction } \\
\text { specification. }\end{array}$ & $\begin{array}{l}\text { Completed } \\
10 / 99\end{array}$ \\
\hline $\begin{array}{l}\text { 17. No non-biodegradable debris would } \\
\text { be deposited in the ROWs. Slash and } \\
\text { other biodegradable debris would be left } \\
\text { in place or disposed of in accordance with } \\
\text { agency requirements. }\end{array}$ & $\begin{array}{l}\text { G5600 } \\
\text { G5600 } \\
\text { G0400/G5600 } \\
\text { G5600 }\end{array}$ & $\begin{array}{l}\text { Task a: Incorporate } \\
\text { requirement into construction } \\
\text { specification. } \\
\text { Task b: Advise construction } \\
\text { contractor. } \\
\text { Task c: Monitor site work. } \\
\text { Task d: Post-Construction } \\
\text { review. }\end{array}$ & $\begin{array}{l}\text { Completed } \\
10 / 99 \\
01 / 31 / 00 \\
09 / 30 / 00 \\
10 / 31 / 00\end{array}$ \\
\hline $\begin{array}{l}\text { 18. If required, mitigation measures } \\
\text { developed during the consultation period } \\
\text { under Section } 7 \text { of the Endangered } \\
\text { Species Act would be adhered to as } \\
\text { specified in the Biological Opinion of the } \\
\text { U.S. DOI Fish and Wildlife Service. } \\
\text { Also, mitigation developed in conjunction } \\
\text { with state and tribal authorities would be } \\
\text { adhered to. }\end{array}$ & G0400/A3400 & $\begin{array}{l}\text { Task a: Survey for peregrine } \\
\text { falcon nests per conditions set } \\
\text { by USFWS. }\end{array}$ & $04 / 30 / 00$ \\
\hline $\begin{array}{l}\text { 19. Hazardous materials would not be } \\
\text { released onto the ground or into streams } \\
\text { or drainage areas. Totally enclosed } \\
\text { containment would be provided for all } \\
\text { trash. All construction waste including } \\
\text { trash and litter, garbage, other solid waste, } \\
\text { petroleum products, and other potentially } \\
\text { hazardous materials would be removed to } \\
\text { a disposal facility authorized to accept } \\
\text { such materials. }\end{array}$ & $\begin{array}{l}\text { G5600 } \\
\text { G5600 } \\
\text { G0400/G5600 } \\
\text { G5600 }\end{array}$ & $\begin{array}{l}\text { Task a: Incorporate } \\
\text { requirement into construction } \\
\text { specification. } \\
\text { Task b: Advise construction } \\
\text { contractor. } \\
\text { Task c: Monitor site work. } \\
\text { Task d: Post-Construction } \\
\text { review. }\end{array}$ & $\begin{array}{l}\text { Completed } \\
10 / 99 \\
01 / 31 / 00 \\
09 / 30 / 00 \\
10 / 31 / 00\end{array}$ \\
\hline $\begin{array}{l}\text { 20. Near residences, the ROW would be } \\
\text { aligned, to the extent practicable, to } \\
\text { reduce impact on the residences and } \\
\text { inhabitants. }\end{array}$ & $\begin{array}{l}\text { G5600 } \\
\text { G5600 }\end{array}$ & $\begin{array}{l}\text { Task a: Determine if } \\
\text { residences are impacted by } \\
\text { ROW. : } \\
\text { Task b: Adjust alignment, if } \\
\text { needed. }\end{array}$ & N/A \\
\hline
\end{tabular}




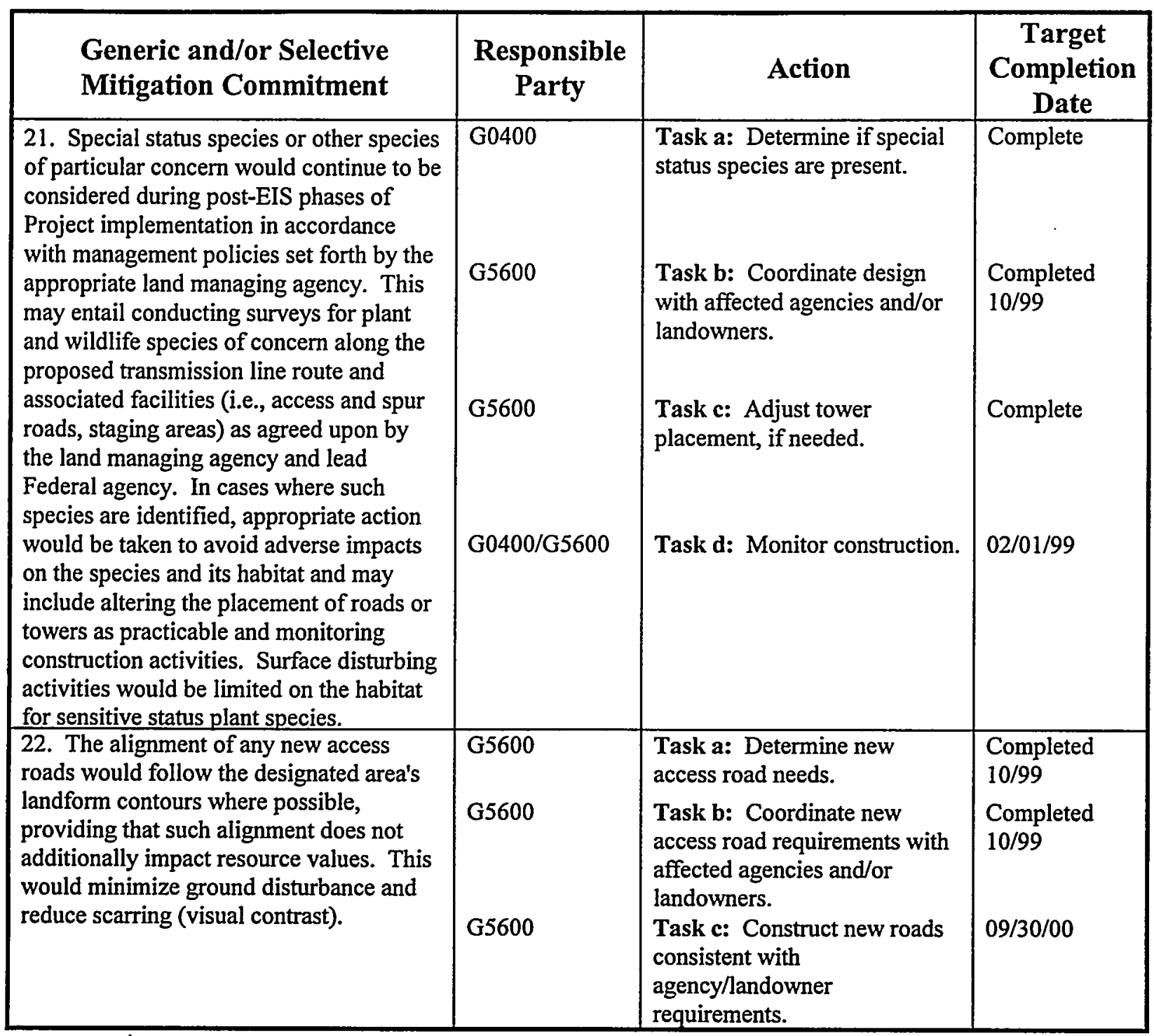


Table 3. Action Plan for Applicable Mitigation Measures, Re-conductoring Topock-Parker No. 1.

\begin{tabular}{|c|c|c|c|}
\hline $\begin{array}{c}\text { Generic and/or Selective Mitigation } \\
\text { Commitment }\end{array}$ & $\begin{array}{l}\text { Responsible } \\
\text { Party }\end{array}$ & Action & $\begin{array}{c}\text { Target } \\
\text { Completion } \\
\text { Date }\end{array}$ \\
\hline $\begin{array}{l}\text { 1. All construction vehicle movement } \\
\text { outside the ROW would be restricted to pre- } \\
\text { designated access, contractor acquired } \\
\text { access, or public roads. No widening or } \\
\text { upgrading of existing access roads would be } \\
\text { undertaken in the area of construction and } \\
\text { operation, except for repairs necessary to } \\
\text { make roads passable, where soils or } \\
\text { vegetation are very sensitive to disturbance. }\end{array}$ & $\begin{array}{l}\text { G5600 } \\
\text { G5600 } \\
\text { G5600/G0400 }\end{array}$ & $\begin{array}{l}\text { Task a: Incorporate } \\
\text { requirement into construction } \\
\text { specification. } \\
\text { Task b: Advise construction } \\
\text { contractor. } \\
\text { Task c: Monitor site work. }\end{array}$ & $\begin{array}{l}\text { Completed } \\
07 / 99 \\
\text { Completed } \\
10 / 99 \\
05 / 01 / 00\end{array}$ \\
\hline $\begin{array}{l}\text { 2. The limits of construction activities would } \\
\text { be predetermined, with activity restricted to } \\
\text { and confined within those limits. No paint or } \\
\text { permanent discoloring agents would be } \\
\text { applied to rocks or vegetation to indicate } \\
\text { limits of survey or construction activity. } \\
\text { There will be no blading of new access roads } \\
\text { unless approved by Western and the land } \\
\text { management agency. }\end{array}$ & $\begin{array}{l}\text { G5600 } \\
\text { G5600 } \\
\text { G5600/G0400 }\end{array}$ & $\begin{array}{l}\text { Task a: Incorporate } \\
\text { requirement into construction } \\
\text { specification. } \\
\text { Task b: Advise construction } \\
\text { contractor. } \\
\text { Task c: Monitor site work. }\end{array}$ & $\begin{array}{l}\text { Completed } \\
07 / 99 \\
\text { Completed } \\
10 / 99 \\
05 / 01 / 00\end{array}$ \\
\hline $\begin{array}{l}\text { 3. In construction areas where re-contouring } \\
\text { is not required, vegetation would be left in } \\
\text { place wherever possible and original contour } \\
\text { would be maintained to avoid excessive root } \\
\text { damage and allow for resprouting. }\end{array}$ & $\begin{array}{l}\text { G5600 } \\
\text { G5600 } \\
\text { G5600/G0400 }\end{array}$ & $\begin{array}{l}\text { Task a: Incorporate } \\
\text { requirement into construction } \\
\text { specification. } \\
\text { Task b: Advise construction } \\
\text { contractor. } \\
\text { Task c: Monitor site work. }\end{array}$ & $\begin{array}{l}\text { Completed } \\
07 / 99 \\
10 / 01 / 99 \\
05 / 01 / 00 \\
\end{array}$ \\
\hline $\begin{array}{l}\text { 4. In construction areas (e.g., marshaling } \\
\text { yards, tower sites, spur roads from existing } \\
\text { access roads) where ground disturbance is } \\
\text { substantial or where re-contouring is } \\
\text { required, surface restoration would occur as } \\
\text { required by the landowner or land } \\
\text { management agency. The method of } \\
\text { restoration normally would consist of } \\
\text { returning disturbed areas back to their natural } \\
\text { contour, reseeding (if required), installing } \\
\text { cross drains for erosion control, placing } \\
\text { water bars in the road, and filling ditches. To } \\
\text { avoid fragmentation of desert bighorn } \\
\text { habitat, fencing would not be used to close } \\
\text { roads or otherwise limit access. Any new } \\
\text { access roads not required for maintenance } \\
\text { would be permanently closed using the most } \\
\text { effective and least environmentally damaging } \\
\text { methods appropriate to that area with } \\
\text { concurrence of the landowner or land } \\
\text { manager. These instances would be reviewed } \\
\text { on a case-by-case basis. }\end{array}$ & G0400/G5600 & $\begin{array}{l}\text { Task a: Prepare construction } \\
\text { operation and maintenance } \\
\text { plan. } \\
\text { Task b: Coordinate } \\
\text { restoration activities with } \\
\text { BLM. } \\
\text { Task c: Determine } \\
\text { landowner restoration needs. }\end{array}$ & $\begin{array}{l}\text { Completed } \\
10 / 99 \\
05 / 01 / 00\end{array}$ \\
\hline
\end{tabular}




\begin{tabular}{|c|c|c|c|}
\hline $\begin{array}{c}\text { Generic and/or Selective Mitigation } \\
\text { Commitment }\end{array}$ & $\begin{array}{c}\text { Responsible } \\
\text { Party }\end{array}$ & Action & $\begin{array}{c}\text { Target } \\
\text { Completion } \\
\text { Date }\end{array}$ \\
\hline $\begin{array}{l}\text { 5. Watering facilities and other range } \\
\text { improvements would be repaired or replaced } \\
\text { if they are damaged or destroyed by } \\
\text { construction activities to their condition prior } \\
\text { to disturbance as agreed to by the parties } \\
\text { involved. }\end{array}$ & G5600 & $\begin{array}{l}\text { Task a: Post-Construction } \\
\text { Review. }\end{array}$ & $05 / 01 / 00$ \\
\hline $\begin{array}{l}\text { 6. Towers and/or ground wire would be } \\
\text { marked with highly visible devices where } \\
\text { required by governmental agencies (e.g., } \\
\text { Federal Aviation Administration) for aircraft } \\
\text { safety. }\end{array}$ & $\begin{array}{l}\text { A3900 } \\
\text { G5600 }\end{array}$ & $\begin{array}{l}\text { Task a: Determine need for } \\
\text { marking. } \\
\text { Task b: Install markers, if } \\
\text { required. }\end{array}$ & $\begin{array}{l}\text { Completed } \\
07 / 99 \\
05 / 01 / 00\end{array}$ \\
\hline $\begin{array}{l}\text { 7. Prior to construction, all supervisory } \\
\text { construction personnel would be instructed } \\
\text { on measures to protect cultural, } \\
\text { paleontological, and ecological resources. }\end{array}$ & G5600/G0400 & $\begin{array}{l}\text { Task a: Advise construction } \\
\text { contractor at pre-construction } \\
\text { conference. }\end{array}$ & $\begin{array}{l}\text { Completed } \\
10 / 99\end{array}$ \\
\hline $\begin{array}{l}\text { 8. Cultural resources would continue to be } \\
\text { considered during post-EIS phases of Project } \\
\text { implementation in accordance with the } \\
\text { programmatic agreement that is being } \\
\text { developed in conjunction with preparation of } \\
\text { the EIS. }\end{array}$ & $\begin{array}{l}\text { G0400/A3400 } \\
\text { G0400/A3400 } \\
\text { G0400/A3400 } \\
\text { G0400/A3400 } \\
\text { G0400/A3400 } \\
\text { G0400/G5600 }\end{array}$ & $\begin{array}{l}\text { Task a: Conduct intensive } \\
\text { survey. } \\
\text { Task b: Conduct } \\
\text { ethnographic study. } \\
\text { Task c: Consult with tribes. } \\
\text { Task d: Consult with SHPO. } \\
\text { Task e: Determine project } \\
\text { modifications. } \\
\text { Task f: Construction } \\
\text { monitoring. }\end{array}$ & $\begin{array}{l}\text { Completed } \\
10 / 99 \\
\text { Completed } \\
10 / 99 \\
\text { Completed } \\
10 / 99 \\
\text { Completed } \\
11 / 99 \\
\text { Completed } \\
10 / 99 \\
05 / 01 / 00\end{array}$ \\
\hline $\begin{array}{l}\text { 9. Western will minimize impacts to active } \\
\text { raptor nest, such as the red-tailed hawk nest } \\
\text { in structure } 37 / 5\end{array}$ & G0400/G5600 & $\begin{array}{l}\text { Task a: Restrict all non- } \\
\text { emergency activities within } \\
\text { one span either side of } \\
\text { structure with active nest } \\
\text { from February to July. }\end{array}$ & $05 / 01 / 00$ \\
\hline $\begin{array}{l}\text { 9. Western will minimize impacts to Desert } \\
\text { bighorn sheep during their lambing season. }\end{array}$ & G0400/G5600 & $\begin{array}{l}\text { Task a: Restrict all non- } \\
\text { emergency activities on the } \\
\text { Topock-Parker \#1 line from } \\
\text { January to June } 30 \text { between } \\
\text { structures } 36 / 1 \text { to } 40 / 1 \text {. }\end{array}$ & $05 / 01 / 00$ \\
\hline $\begin{array}{l}\text { 10. Western would respond to individual } \\
\text { complaints of radio or television interference } \\
\text { generated by the transmission line by } \\
\text { investigating the complaints and } \\
\text { implementing appropriate mitigation } \\
\text { measures (e.g., adjusting or using filtering } \\
\text { devices on antennae). The transmission line } \\
\text { would be patrolled on a regular basis so that } \\
\text { damaged insulators or other transmission line } \\
\text { materials, which could cause interference, are } \\
\text { repaired or replaced. }\end{array}$ & G5000 & $\begin{array}{l}\text { Task a: Respond to } \\
\text { complaints. } \\
\text { Task b: Transmission line } \\
\text { Patrols. } \\
\text { Task c: Replace damaged } \\
\text { insulators or conductor. }\end{array}$ & $\begin{array}{l}\text { Ongoing } \\
\text { Ongoing } \\
\text { Semi-annual } \\
\text { As needed }\end{array}$ \\
\hline
\end{tabular}




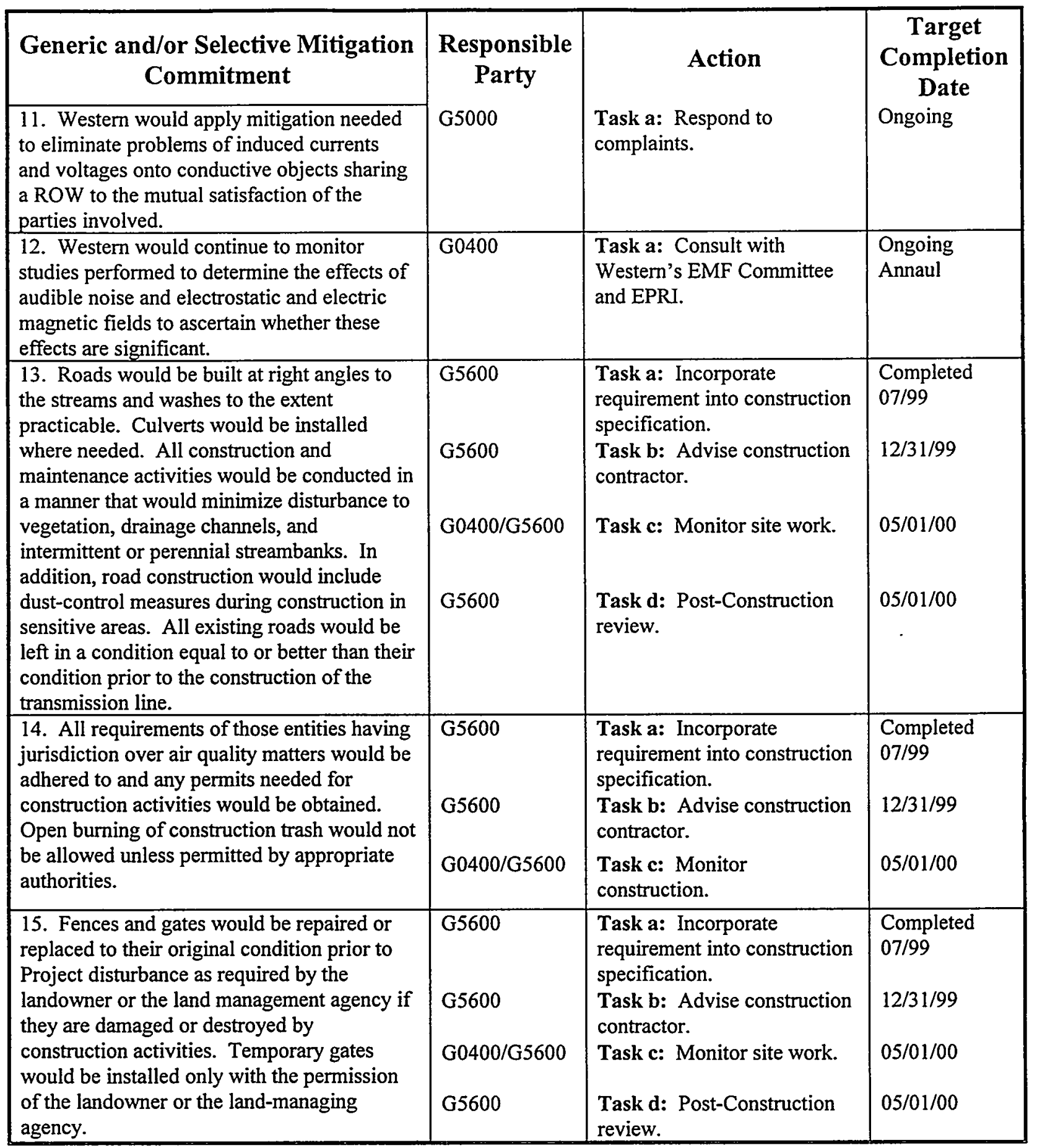




\begin{tabular}{|c|c|c|c|}
\hline $\begin{array}{l}\text { Generic and/or Selective Mitigation } \\
\text { Commitment }\end{array}$ & \multirow{2}{*}{$\begin{array}{l}\text { Responsible } \\
\quad \text { Party } \\
\text { A3900 }\end{array}$} & \multirow{2}{*}{$\begin{array}{l}\quad \text { Action } \\
\text { Task a: Design to minimize } \\
\text { corona. } \\
\text { Task b: Monitor } \\
\text { construction activities. }\end{array}$} & \multirow{2}{*}{$\begin{array}{l}\text { Target } \\
\text { Completion } \\
\text { Date } \\
\text { Complete }\end{array}$} \\
\hline $\begin{array}{l}\text { 16. Transmission line materials would be } \\
\text { designed and tested to minimize corona. } \\
\text { Tension would be maintained on all insulator } \\
\text { assemblies to assure positive contact between } \\
\text { insulators, thereby avoiding sparking. } \\
\text { Caution would be exercised during } \\
\text { construction to avoid scratching or nicking } \\
\text { the conductor surface, which may provide } \\
\text { points for corona to occur. }\end{array}$ & & & \\
\hline $\begin{array}{l}\text { 17. Nonspecular conductors, groundwires } \\
\text { and dulled structure components would be } \\
\text { used to reduce visual impacts. }\end{array}$ & A3900 & $\begin{array}{l}\text { Task a: Incorporate } \\
\text { requirements into } \\
\text { construction specification. }\end{array}$ & $\begin{array}{l}\text { Completed } \\
07 / 99\end{array}$ \\
\hline \multirow{4}{*}{$\begin{array}{l}\text { 18. No non-biodegradable debris would be } \\
\text { deposited in the ROWs. Slash and other } \\
\text { biodegradable debris would be left in place } \\
\text { or disposed of in accordance with agency } \\
\text { requirements. }\end{array}$} & G5600 & $\begin{array}{l}\text { Task a: Incorporate } \\
\text { requirement into construction } \\
\text { specification. }\end{array}$ & $\begin{array}{l}\text { Completed } \\
07 / 99\end{array}$ \\
\hline & G5600 & $\begin{array}{l}\text { Task b: Advise construction } \\
\text { contractor. }\end{array}$ & \\
\hline & G0400/G5600 & Task c: Monitor site work. & $05 / 01 / 00$ \\
\hline & G5600 & $\begin{array}{l}\text { Task d: Post-Construction } \\
\text { review. }\end{array}$ & $05 / 01 / 00$ \\
\hline $\begin{array}{l}\text { 19. If required, mitigation measures } \\
\text { developed during the consultation period } \\
\text { under Section } 7 \text { of the Endangered Species } \\
\text { Act would be adhered to as specified in the } \\
\text { Biological Opinion of the U.S. DOI Fish and } \\
\text { Wildlife Service. Also, mitigation developed } \\
\text { in conjunction with state and tribal authorities } \\
\text { would be adhered to. }\end{array}$ & G0400/A3400 & $\begin{array}{l}\text { Task a: Survey for peregrine } \\
\text { falcon nests per conditions } \\
\text { set by USFWS. }\end{array}$ & $\begin{array}{l}\text { Completed } \\
04 / 99\end{array}$ \\
\hline \multirow{4}{*}{$\begin{array}{l}\text { 20. Hazardous materials would not be } \\
\text { released onto the ground or into streams or } \\
\text { drainage areas. Totally enclosed containment } \\
\text { would be provided for all trash. All } \\
\text { construction waste including trash and litter, } \\
\text { garbage, other solid waste, petroleum } \\
\text { products, and other potentially hazardous } \\
\text { materials would be removed to a disposal } \\
\text { facility authorized to accept such materials. }\end{array}$} & G5600 & $\begin{array}{l}\text { Task a: Incorporate } \\
\text { requirement into construction } \\
\text { specification. }\end{array}$ & $\begin{array}{l}\text { Completed } \\
07 / 99\end{array}$ \\
\hline & G5600 & $\begin{array}{l}\text { Task b: Advise construction } \\
\text { contractor. }\end{array}$ & $12 / 31 / 99$ \\
\hline & G0400/G5600 & Task c: Monitor site work. & $05 / 01 / 00$ \\
\hline & G5600 & $\begin{array}{l}\text { Task d: Post-Construction } \\
\text { review. }\end{array}$ & \\
\hline \multirow[t]{2}{*}{$\begin{array}{l}\text { 21. Near residences, the ROW would be } \\
\text { aligned, to the extent practicable, to reduce } \\
\text { impact on the residences and inhabitants. }\end{array}$} & G5600 & $\begin{array}{l}\text { Task a: Determine if } \\
\text { residences are impacted by } \\
\text { ROW. }\end{array}$ & $\mathrm{N} / \mathrm{A}$ \\
\hline & G5600 & $\begin{array}{l}\text { Task b: Adjust alignment, if } \\
\text { needed. }\end{array}$ & N/A \\
\hline
\end{tabular}




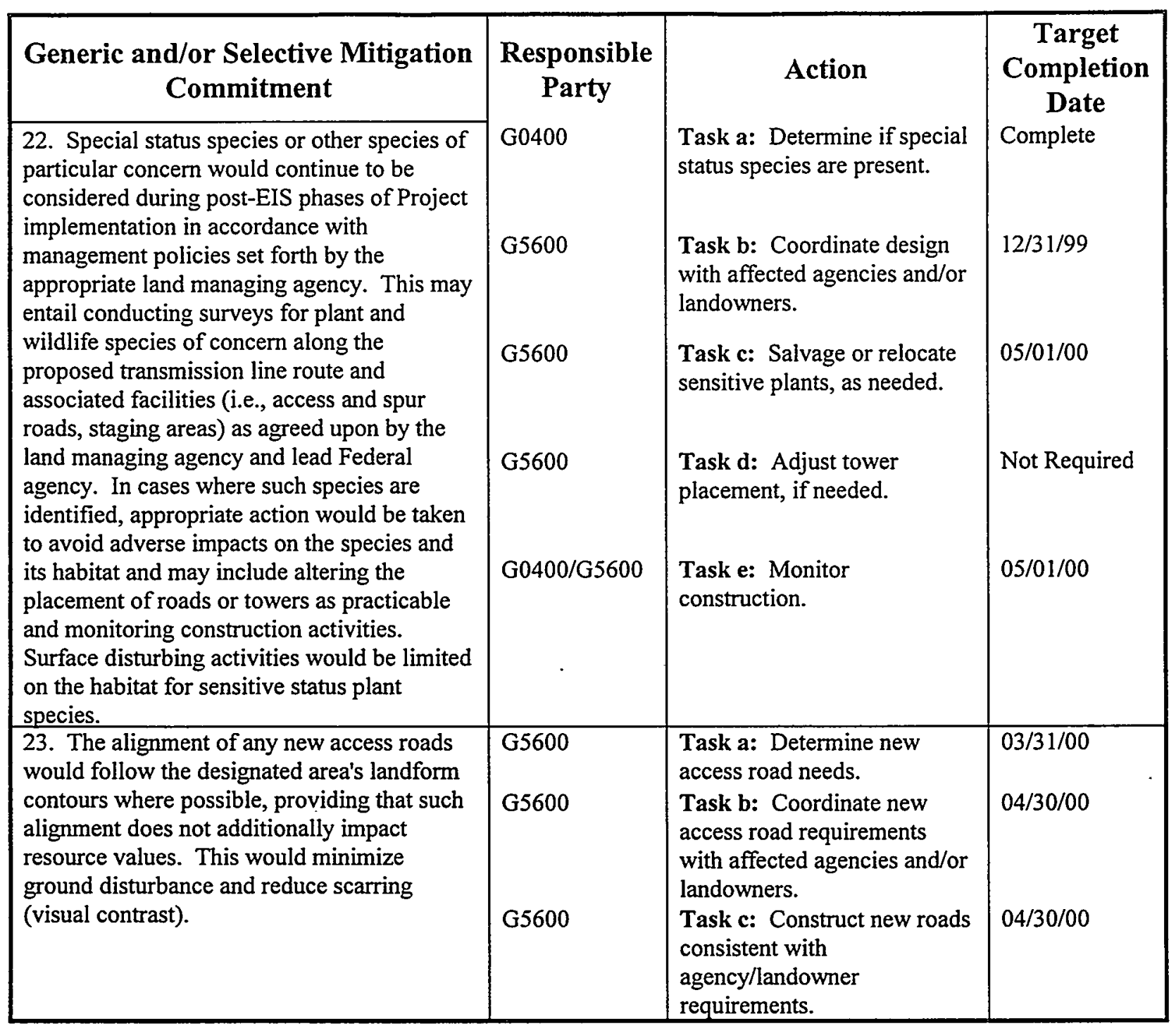

